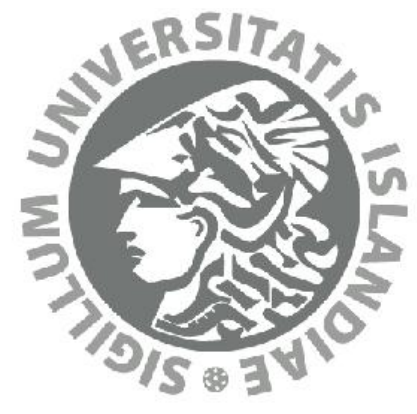

Microbial methane oxidation at the Fíflholt landfill in Iceland

Alexandra Kjeld

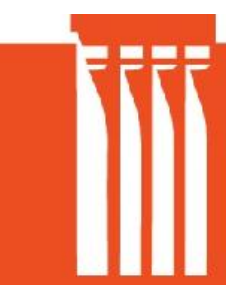

Faculty of Civil and

Environmental Engineering

University of Iceland 



\title{
Microbial Methane Oxidation at the Fíflholt landfill in Iceland
}

\author{
Alexandra Kjeld \\ 60 ECTS thesis submitted in partial fulfillment of a \\ Magister Scientiarum degree in Environmental Engineering
}

Advisors

Alexandre Cabral, Université de Sherbrooke

Lúðvík E. Gústafsson, Icelandic Association of Local Authorities Hrund Ó. Andradóttir, University of Iceland Helga J. Bjarnadóttir, EFLA Consulting Engineers

Faculty Representative

Peter Kjeldsen, DTU

Faculty of Civil and Environmental Engineering

School of Engineering and Natural Sciences

University of Iceland

Reykjavik, December 2013 

Microbial Methane Oxidation at the Fíflholt landfill in Iceland 60 ECTS thesis submitted in partial fulfilment of a Magister Scientiarum degree in Environmental Engineering

Copyright (C) 2013 Alexandra Kjeld

All rights reserved

Faculty of Civil and Environmental Engineering

School of Engineering and Natural Sciences

University of Iceland

VR II, Hjarðarhaga 2-6

107 Reykjavík

Iceland

Telephone: 5254000

Bibliographic information:

Kjeld, A., 2013, Microbial Methane Oxidation at the Fiflholt Landfill in Iceland, Master's thesis, Faculty of Civil and Environmental Engineering, University of Iceland, pp. 87.

Printing: Pixel prentpjónusta ehf.

Reykjavik, Iceland, December 2013 


\section{Abstract}

Methane oxidizing biosystems have received wide recognition in the past years as a cost effective and important means to reduce emissions from landfills. However, there is no documentation of the oxidation capacity of Icelandic landfill covers to date and there is limited information on microbial methane oxidation in boreal climates. The present study was carried out to qualitatively assess the oxidation capacity of the current top cover of one of the cells of the Fíflholt landfill, located in West Iceland, using the gas profile method $\left(\mathrm{CO}_{2} / \mathrm{CH}_{4}\right.$ ratio). The landfill has no gas recovery system and the cover is composed of 15$25 \mathrm{~cm}$ crushed wood overlain by about $1 \mathrm{~m}$ of gravelly sand with $7 \%$ organic matter content. Sampling probes were installed at two locations on cell 2 at different depths $(5$ to $120 \mathrm{~cm})$ and point gas concentration measurements were carried out during the autumn and the winter of 2012-2013. It was observed that atmospheric air penetrated deep into the cover and oxidation activity was observed in the gas profiles. The oxidation zone was situated mainly below $40 \mathrm{~cm}$ from the surface and went as deep as about $1 \mathrm{~m}$ below surface, i.e. to the base of the cover. Oxidation efficiencies ranged from 0 to $99 \%$, reaching the maximal value between 30 and $60 \mathrm{~cm}$ depth, with mean values $59 \%$ and $77 \%$ for the two sampling locations and for the study period. It must be highlighted that relatively high oxidation efficiencies were obtained during the winter, indicating that methane oxidation can take place throughout the year. The study also suggests that the $10 \%$ default oxidation factor proposed by the IPCC model may underestimate the actual oxidation capacity of the cover at the Fiflholt landfill, although a more thorough and continuous measurement campaign is needed to confirm this hypothesis. 


\section{Útdráttur}

Lífræn yfirborðslög sem oxa metan hafa hlotið viðurkenningu á undanförnum árum sem hagkvæm og áhrifarík leið til að draga úr losun gróðurhúsalofttegunda frá urðunarstöðum. Oxunarhæfni yfirborðslaga á íslenskum urðunarstöðum hefur hinsvegar ekki verið rannsökuð og pað er takmörkuð pekking á metanoxun örvera í köldu loftslagi. Pessari rannsókn var hleypt af stað til að meta hlutfallslega oxunarhæfni núverandi yfirborðslags í rein 2 á urðunarstaðnum að Fíflholti á Mýrum, Borgarbyggð, með pví að nota gasprófilaðferðina (hlutfall $\mathrm{CO}_{2} / \mathrm{CH}_{4}$ ). Urðunarstaðurinn er ekki búinn gassöfnunarkerfi og yfirborðið er samansett af $15-25 \mathrm{~cm}$ timburkurli undir u.p.b. $1 \mathrm{~m}$ af malarkenndum sandi með 7\% lífrænu innihaldi. Mælirör voru sett niður á tveim stöðum á rein 2 á mismunandi dýpi $(5-120 \mathrm{~cm})$ og punktmælingar gerðar á haust- og vetrarmánuðum 2012-2013. Andrúmsloft smaug djúpt niður í yfirborðslagið og mikil oxunarvirkni sást í gasprófílum. Oxunin átti sér aðallega stað á $40 \mathrm{~cm}$ dýpi og neðar, mögulega alveg frá botni yfirborðslagsins eða frá $1 \mathrm{~m}$ dýpt. Oxunarhlutfall var á bilinu 0 til $99 \%$ og náði hámarki á 30 - 60 cm dýpi, eða meðalgildum 59\% og 77\% fyrir hvort tveggja staðanna á öllu tímabilinu. Athygli vakti að tiltölulega mikil oxun átti sér stað um vetur, sem bendir til pess að oxun metans geti átt sér stað árið um kring. Rannsóknin gefur einnig vísbendingu um að oxunarhlutfallið $10 \%$ sem IPCC líkanið mælir með vanmeti raunverulega oxunarhæfni yfirborðslagsins á Fíflholti, en frekari og samfelldra mælinga er pörf pessu til staðfestingar. 


\section{Table of Contents}

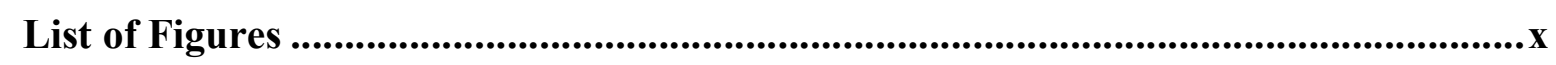

List of Tables................................................................................................................ii

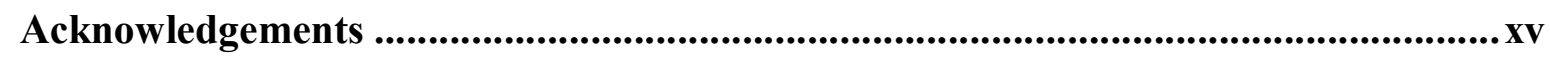

1 Background and objectives ..........................................................................................

2 Theoretical background ............................................................................................................

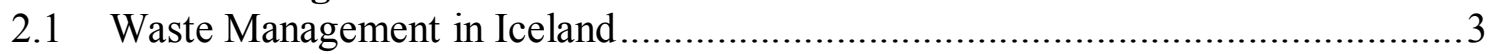

2.2 Landfill Gas Generation ...........................................................................

2.3 Gas Transport in Soil and Emissions ..............................................................

2.4 Methane Emission Mitigation......................................................................

2.4.1 Extraction, Flaring and Utilization.........................................................

2.4.2 Aerobic Landfills ..........................................................................

2.5 Microbial Methane Oxidation...................................................................

2.5.1 Methanotrophic Bacteria ...................................................................

2.5.2 Oxidation Kinetics and Factors of Influence …………………………...... 8

2.5.3 Passive Methane Oxidation Biosystem (PMOB) ………………….............

2.6 Quantification and Estimation ...................................................................... 10

2.6.1 Methane Generation Estimation ..............................................................11

2.6.2 Methane Emission Estimation .................................................................11

2.6.3 Methane Oxidation Estimation ...............................................................13

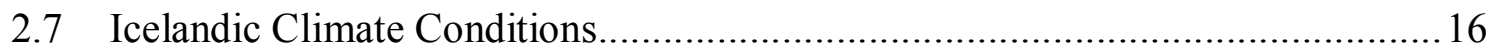

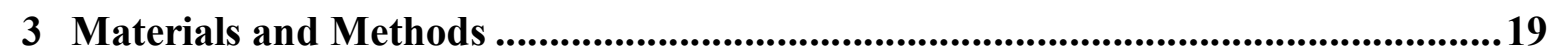

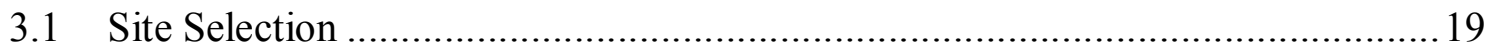

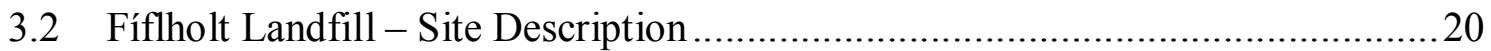

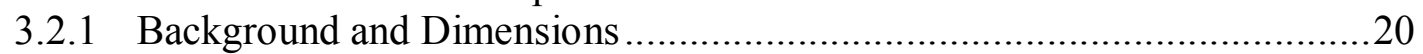

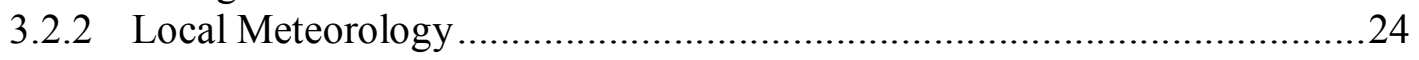

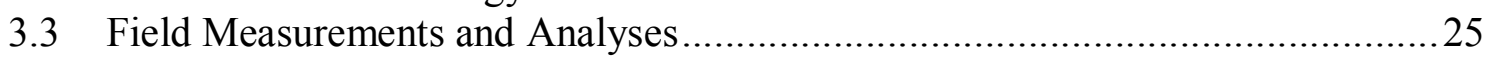

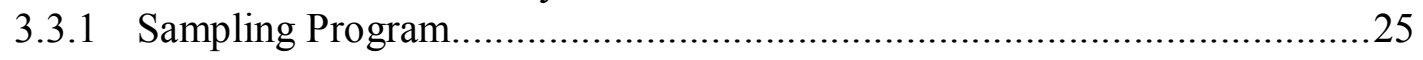

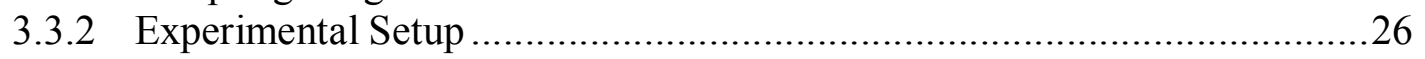

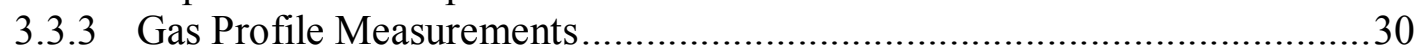

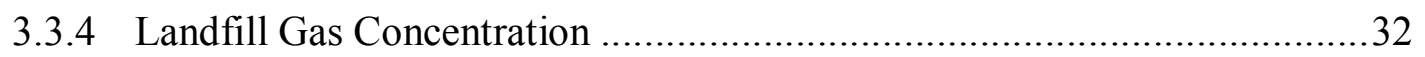

3.3.5 Soil Temperature Measurements ………………………………………......33

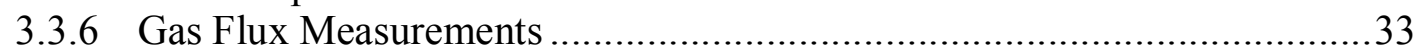

3.3.7 Properties of the Top Cover and Soil Analysis.............................................35

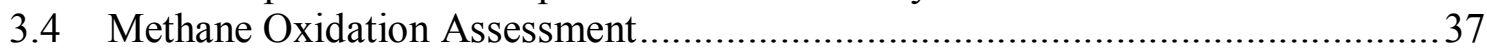

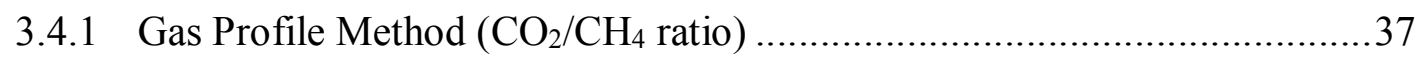

3.4.2 Oxidation Efficiency (Eff $f_{\text {ox }}$ ) Calculation .....................................................38

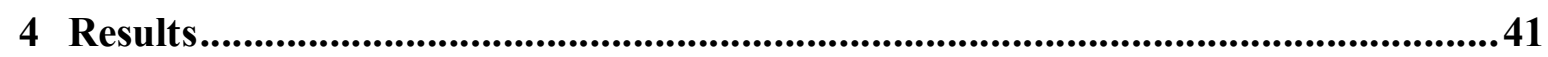

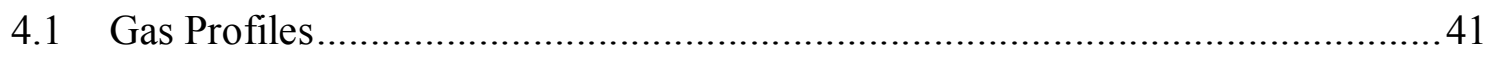


4.1.1 General Results and Reliability ................................................... 41

4.1.2 Atmospheric Air Penetration ............................................................ 42



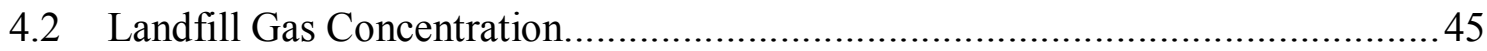

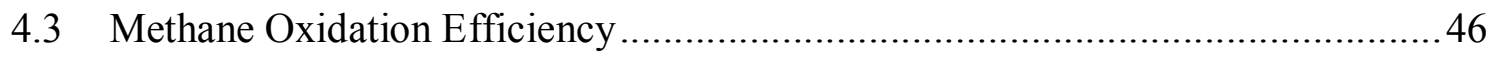

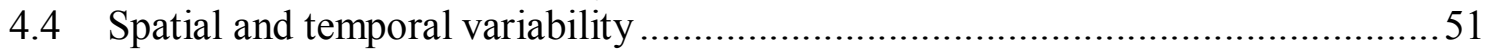

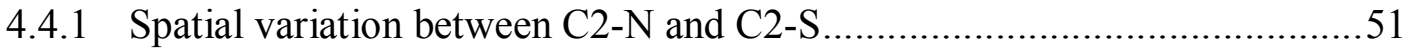

4.4.2 Atmospheric Pressure.........................................................................52

4.4.3 Soil temperature and atmospheric temperature .......................................5 54

4.4.4 Accumulated precipitation and soil water content ..................................5

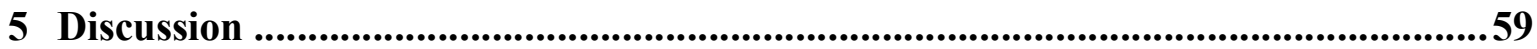

5.1 Methane Oxidation at Fíflholt and Suitability of Passive Methane Oxidation

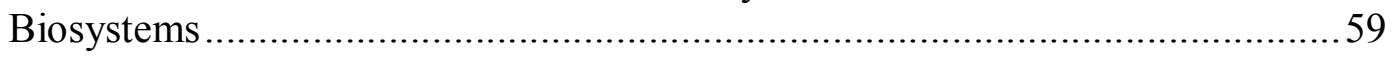

5.2 Measured Gas Fluxes on Selected Dates.........................................................6 60

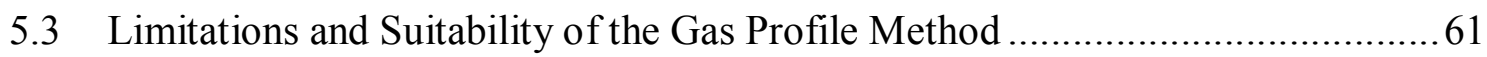

5.4 Choice of IPCC Methane Oxidation Factor to Estimate Methane Emissions ....... 62

5.5 New Requirements and IPCC Modelling at Fíflholt.......................................6 64

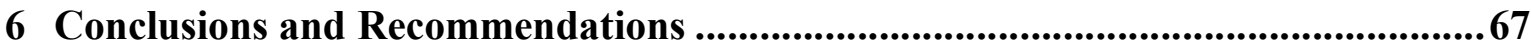

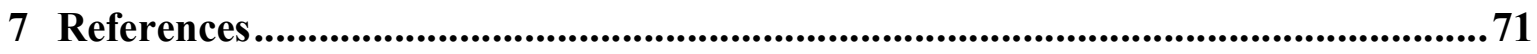

Appendix A: Gas Profile Results ................................................................................... 77

Appendix B: Fíflholt Waste Inventory .................................................................8

Appendix C: Preliminary Gas Flux Measurements at the Álfsnes Landfill ................85 


\section{List of Figures}

Figure 1 Waste treatment and disposal in Iceland in 2011. Black triangles are landfills for municipal waste, landfills with blue underlines can be classified as landfills for isolated settlements, green triangles are landfills for inert waste and red triangles are incinerators, all with energy recovery [Scharff et al., 2011].

Figure 2 Generalized phases in generation of landfill gases (I-initial adjustment, IItransition phase, III-acid phase; IV-methane fermentation, $V$ - maturation phase) (Tchobanoglous et al., 1993).

Figure 3 Configuration of passive methane oxidation biocover (PMOB). Landfill gas (LFG) generated in the waste layer goes through a gas distribution layer $(G D L)$ of very porous material and then through a methane oxidation layer (MOL) of an adequate substrate.

Figure 4 Location of the Fiflholt landfill in Western Iceland [Map: LMÍ].

Figure 5 Plan view of the Fiflholt landfill, Borgarbyggð, West Iceland. The black horizontal lines denote the layout of cells 1-4, cell no. 4 being at the top of the figure and cells 1-3 right below. A fence, indicated by the yellow line, surrounds the landfilling area and the purple line denotes the total area reserved for landfilling. (VERKÍS Consulting Engineers).

Figure 6 Location of sampling tubes on top of cell 2 at Fiflholt landfill, identified as C2-N and C2-S. Sampling tubes are situated right next to monitoring wells. Coloured lines are explained in Figure 5 [VERKÍS Enginering Consultants].

Figure 7 Annual waste categories and quantities 2003-2006 at the Fiflholt landfill, according to landfill inventories, i.e. when cell 2 was being filled. Cover materials are not included here. A more detailed inventory is presented in Appendix B.

Figure 8 A view to the north over sampling tubes on cell 2 at Fiflholt landfill, south end (C2-S). Monitoring well to the left, protected by tires, Photo: AK, September 2012.

Figure 9 Sampling tubes at C2-N at Fiflholt landfill, north end. Tubes are protected by wooden pallet. Photo: AK, October 2012.

Figure 10 Profile view of gas measurement setup in Cell 2 at Fiflholt landfill.

Figure 11 Drawing of $40 \mathrm{~cm}$ sampling tube used for gas profile measurements, profile and $3 D$ image. All numbers are in $\mathrm{mm}$. 
Figure 12 Shallow sampling tubes $(20 \mathrm{~cm}$ in the front and $5 \mathrm{~cm}$ at the back) being pushed up through the surface by forces of frost heave. Photo: AK.

Figure 13 Gas profile measurements at Fiflholt landfill using the Geotechnical Instruments GA2000 Plus. Photo: GM, Oct 2012.

Figure 14 Flux curve on handheld display unit. $C_{\text {Soil }}$ is the target gas concentration in the soil, $C_{A i r}$ is the target gas air concentration, $350 \mathrm{ppm}$ in the case of carbon dioxide (West Systems, 2007). Figure from West Systems Handbook, 2007.

Figure 15 Gas flux measurements at the Fiflholt landfill, using the West Systems portable diffuse flux meter. Photo: AK, Nov 2012.

Figure 16 Excavated cover from Cell 2 at the Fiflholt landfill. A sample was extracted from the excavated mound for particle size distribution analysis. Decomposing chopped wood is visible at the bottom of the cover as well as scattered large boulders from the top cover. Photo: AK, Dec 2012.

Figure 17 Granulometric curve for cover soil sample from the Fiflholt landfill. Sáldur $(\%)=$ Percent passing (\%), Möskvastcerð (mm) = Sieve size (mm).

Figure 18 Gas concentration profiles (\% v/v) for C2-N during the study period, from August 2012 to August 2013.

Figure 19 Gas concentration profiles (\% v/v) for C2-S during the study period, from August 2012 to August 2013.

Figure 20 An overview of oxidation efficiencies Effox vs. corresponding depths during the study period at C2-S. Negative Eff ox values, qualitatively equal to 0, are situated on the $y$-axis.

Figure 21 An overview of oxidation efficiencies Eff $f_{\text {ox }}$ vs. corresponding depths during the study period at C2-N. Negative Eff ox values, qualitatively equal to 0, are situated on the $y$-axis.

Figure 22 Average oxidation efficiency profiles at $C 2-S$ and $C 2-N$ and mean profile for both locations for the entire study period.

Figure 23 48-hour air pressure (hPa) development during each sampling date of the study, August 2012 - August 2013. The blue vertical lines denote the time of sampling.

Figure 24 Soil temperature profiles, measured at C2-N and C2-S at the Fiflholt landfill during the study period. 
Figure 25 Soil temperature at depth $i, T_{\text {soil_ } i}\left({ }^{\circ} \mathrm{C}\right)$, vs oxidation efficiency at depth $i$, Eff $_{\text {ox_i }}(\%)$, for both measurement locations $C 2-S$ and $C 2-N$ during the study period.

Figure 26 Atmospheric temperature vs maximum oxidation efficiencies, max Eff ox, at C2-S and C2-N during the study period.

Figure 27 A photo of the ground on top of Cell 2 at the Fiflholt landfill, next to C2-N, taken during sampling on November 18,2012 . The temperature was $1.9^{\circ} \mathrm{C}$ and the ground was still frozen. Photo: AK.

Figure 28 Accumulated precipitation (24 hrs, $48 \mathrm{hrs}, 7$ days) (mm) vs maximum oxidation efficiency (max Effox) (\%) for $C 2-S$ and $C 2-N$ during the study period.

Figure 29 Estimated methane generation [Gg/y] at cells 1-3 and cell 2 of the Fiflholt landfill, assuming $0 \%$ and $50 \%$ methane oxidation, modelled using the localized IPCC (2006) first-order-decay model. 


\section{List of Tables}

Table 1 Local weather conditions during the time of field measurements at the Fiflholt landfill, from August 2012 to August 2013. Mean values during time of sampling. All information obtained from the IMO weather station situated at the Fiflholt landfill, except for atmospheric pressure (adjusted to mean sea level), estimated from weather stations at Stykkishólmur and Húsafell.

Table 2 A summary of sampling dates and field measurements performed during the study period August 2012 - August 2013 at the Fiflholt landfill.

Table 3 Overview of measurements performed for this study and origin of equipment used.

Table 4 Summary of sampling tubes and tube lengths at locations $C 2-N$ and $C 2-S$ on Cell 2 at the Fiflholt landfill.

Table 5 Accuracy of gas concentration measurements of GA 2000 Plus Gas Analyser (Geotechnical Instruments, 2006).

Table 6 Summary of recent gas concentration measurements from monitoring wells C2-S and C2-N at Cell 2 at the Fiflholt landfill (Atli Geir Júliusson, 2011; Mannvit, 2012).

Table 7 A summary of gas concentrations in monitoring wells at C2-S and $C 2-N$ measured at the Fiflholt landfill during this study.

Table 8 Example of Eff ox calculations, using gas concentration values measured at sampling tubes and monitoring well at C2-S on February 28, 2013. All results and calculations can be seen in Appendix A.

Table 9 A summary of methane and carbon dioxide concentrations and calculated oxidation efficiencies for each tube depth at C2-N and C2-S during the study. All results and calculations are provided in Appendix A.

Table 10 A summary of maximum oxidation efficiency values, Effox, at corresponding depths for both monitoring spots, C2-S and C2-N.

Table 11 Gas flux ranges $\left[\mathrm{g} / \mathrm{m}^{2} / \mathrm{d}\right]$ measured during the study period in proximity to $C 2-N$ and $C 2-S$, i.e. within $10 m$ distance of sampling tubes. $n=$ number of measurements (Meyvantsdóttir, 2013, unpublished data). 



\section{Acknowledgements}

This study was supported by The Association of Local Authorities in Iceland (Samband íslenskra sveitarfélaga), EFLA Consulting Engineers (EFLA verkfræðistofa) and The Solid Waste Management of West Iceland (Sorpurðun Vesturlands). Soil analysis was carried out with support of the Innovation Center Iceland (Nýsköpunarmiðstöð Íslands).

My sincere thanks to Alexandre R. Cabral, for continuous support and expert advice, and to Lúovík E. Gústafsson, Helga J. Bjarnadóttir and Hrund Ó. Andradóttir for excellent comments and feedback.

A particular thanks to Sveinn Ingi Reynisson for invaluable technical assistance and overall support throughout the study, and to Porsteinn Eybórsson and Guðrún Meyvantsdóttir for their field assistance. Thanks also go to experts at EFLA Consulting Engineers and at the Innovation Center Iceland and finally to Matthías Kjeld, Marcella Iniguez and Símon Reynir Sveinsson for their encouragement and motivation. 


\section{Background and objectives}

Landfill gas is produced by microbial anaerobic degradation of organic waste and is mainly composed of methane and carbon dioxide, typically in the concentrations of $55-60 \%$ methane and 40-45\% carbon dioxide (Scheutz et al., 2009). Methane is a greenhouse gas up to 25 to times more potent than carbon dioxide as it is more effective at absorbing infrared radiation (Intergovernmental Panel on Climate Change (IPCC), 2007). Landfills are therefore responsible for $<5 \%$ of overall global greenhouse gas emissions today or about $18 \%$ of global $\mathrm{CH}_{4}$ emissions (Bogner et al., 2007) and rank among the largest anthropogenic $\mathrm{CH}_{4}$ sources worldwide, second largest in Europe (EEA, 2009), making them a good target for mitigation (Forster et al., 2007).

Methane emissions from landfills are a product of landfill gas generation, recovery and microbial $\mathrm{CH}_{4}$ consumption, both depending largely of site dependent soil specific and meteorological factors. Many modern landfills have gas collection systems that either recover the gas for energy recovery or incineration. These systems can, however, only recover a fraction of the gas due to leaks in the system and because of fugitive gas emissions that escape through cracks other preferential pathways in the cover (e.g. Börjesson et al., 2007, Scheutz et al., 2009). In smaller and older landfills, the methane production is too low for recovery or flaring, and installation of a gas extraction system is inefficient (HuberHumer et al., 2009), thus allowing all of the generated gas to pass through the cover soil.

The technique of enhancing the activity of methanotrophic bacteria in the cover soil to oxidize methane has received wide recognition in the past years as a cost-effective and important means to reduce fugitive emissions (e.g. Gebert and Gröngröft, 2006; HuberHumer et al., 2009; Chanton et al, 2011, Scheutz et al., 2009). It serves as a complementary strategy for methane emissions escaping gas collection, and for emissions mitigation at smaller and older sites without gas recovery systems. Since gas is still being generated after the landfill is no longer in operation, landfill after-care with oxidizing biosystems is furthermore considered among key mitigating measures to reduce long-term greenhouse gas emissions from landfills (Bogner et al., 2007).

With the adoption of EU directive and Icelandic regulation no. 738/2003 on landfill waste, landfills in Iceland receiving biodegradable waste were required to collect landfill gas after July 16, 2009. The majority of Icelandic landfills receiving biodegradable waste are relatively small, and a study carried out in 2010 (Júlíusson, 2011) suggested that most landfills in Iceland generate too little methane for it to be technically or economically feasible to collect biogas, as required by regulation.

The Fiflholt landfill in West-Iceland, latitude $64^{\circ}$, is one of the larger Icelandic landfills although small in international comparison, roughly $10 \mathrm{~km}$ from the shore, receiving biodegradable waste from rural and urban areas in the region. It has no gas collection system, considered technically possible by Júlíusson (2011), but further studies were recommended to ascertain technical or economical feasibility. 
No knowledge of the oxidation capacity of Icelandic landfill covers exists to date, and since there is limited information on microbial methane oxidation in boreal climates, a recent TAIEX mission report (Scharff et al., 2011) recommended a demonstration project to gather information on the current situation. The Icelandic Association of Local Authorities therefore lanced a project in cooperation with The Solid Waste Management of West Iceland Regional Office, EFLA Consulting Engineers and the University of Iceland to study the oxidation capacity of the current cover at the Fíflholt landfill.

For this study, the oxidation capacity of the current soil cover at Fiflholt is assessed using the gas profile method $\left(\mathrm{CO}_{2} / \mathrm{CH}_{4}\right.$ ratio) (Gebert et al., 2011). Specifically, the project aims to answer the following research questions:

- Is there evidence that landfill gas passing through the soil cover at the Fíflholt landfill is being oxidized, even during the cold months of the year?

- Can this oxidation be assessed, i.e. using the gas profile method?

- Is the default $10 \%$ oxidation value used in the IPCC model for developped countries a reasonable value?

The theoretical background of this study, e.g. waste management in Iceland, landfill gas generation, gas transport mechanisms and microbial methane oxidation, is presented in chapter 2. Materials and methods of the study, including a site description of the Fiflholt landfill, the experimental program and methods used to assess the methane capacity of the soil cover, are detailed in chapter 3. Gas profiles and calculated oxidation efficiencies are presented in chapter 4, followed by a discussion on the results, including emission estimations and limitations of the method in chapter 5. 


\section{Theoretical background}

In this chapter, the state-of-the-art regarding microbial methane oxidation is reviewed. A brief introduction on waste management in Iceland is followed by a review of landfill gas generation, gas transport mechanisms and biogas utilization schemes. Microbial methane oxidation is described next, followed by a presentation of measurement and assessment methods. Finally, Icelandic climate conditions are described, giving context to the results of this study.

\subsection{Waste Management in Iceland}

For most of the 20th century there were many small solid waste disposal sites in Iceland, located close to origins of waste generations. The most common form of waste management up until the 1970s was open burning of waste. Some communities even disposed of their waste into the ocean (The Environmental Agency of Iceland (EAI), 2012). Municipal landfills were set into operation in Reykjavík (Gufunes) in 1967 and soon after in Akureyri (Glerárdalur) and Selfoss in the 1970s and 80s.

In the late 1980s and 1990s waste incinerators were opened across the country and in 2010 a total of six waste incinerators were in use, although since then many of them have closed. Open burning of waste was banned in 1999 and the last place to use such methods was the island of Grímsey, which stopped doing so in 2011. In the past years, the trend has been toward fewer managed landfills, often run by a joint cooperation of municipalities. Landfilling of waste is today the predominant waste disposal strategy in Iceland.

Between 1995 and 2008, waste production per capita increased from 1,482 $\mathrm{kg}$ to 2,158 $\mathrm{kg}$, but since then it decreased to $1,596 \mathrm{~kg}$ in 2010 (Ministry for the Environment and Natural Resources, 2013). In 2002, 260,000 tons of waste was generated in Iceland, of which $67 \%$ was landfilled (Kamsma \& Meyles, 2003). In 2003, there were 32 registered landfills scattered along the coast of Iceland, 7 of which intended only for inert waste (EAI, 2012). In 2010, a total of approx 480,000 tons of waste was generated in Iceland, about $32 \%$ of which was landfilled (Ministry for the Environment and Natural Resources, 2013). The distribution of landfills and incinerators in Iceland in 2011 is presented in Figure 1. In 2013, a total of 26 landfills were in operation in Iceland, 6 of which were for inert waste.

In the capital area, Reykjavík and its neighbouring municipalities Kópavogur, Hafnarfjörður, Garðabær, Seltjarnarnes, Mosfellsbær and Álftanes have since 1991 run an independent firm, SORPA, which handles solid waste from capital area. Raw material is produced from recycled waste and landfill gas is extracted for power generation. Compost is also produced from part of the biodegradable waste. SORPA futhermore plans to build a bioreactor in the near future. The SORPA landfill at Álfsnes is a bale landfill and it is since 1997 the only landfill currently recovering landfill gas, although a gas collection system is in preparation at the Akureyri landfill (Glerárdalur) in North Iceland. 


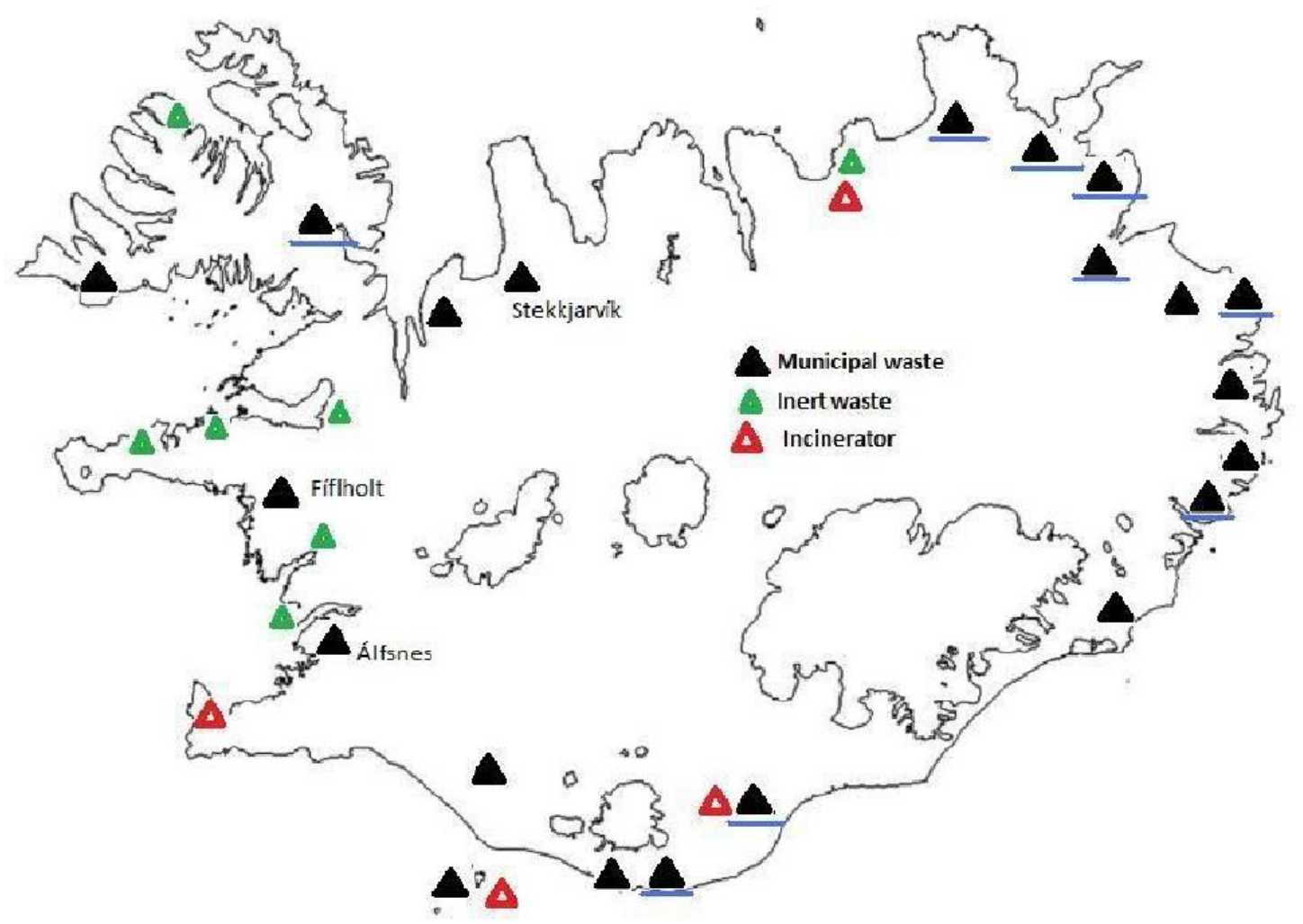

Figure 1 Waste treatment and disposal in Iceland in 2011. Black triangles are landfills for municipal waste, landfills with blue underlines can be classified as landfills for isolated settlements, green triangles are landfills for inert waste and red triangles are incinerators, all with energy recovery [Scharff et al., 2011].

The waste sector accounted for the fourth largest contributor, or 5\%, of greenhouse gas emissions in Iceland in 2010 (EAI, 2012). Of these emissions, about 89\% were methane emissions from landfills, while the remainder was from wastewater treatment plants, waste incineration and composting.

Waste collection strategy is different depending on the region. It is only very recently that househould waste containers for sorted waste were made available for collection by authorities. For all other purposes there are recycling stations distributed throughout the capital area. Recycling and biological treatment of waste started in the 1990s, as well as the treatment of hazardous waste, but before that hazardous waste was landfilled or burned with other waste. Iceland is a member of the EEA and as such adopted the European Landfill Directive into Icelandic legislation, by adopting Icelandic law. no. 55/2003 and regulation no. $738 / 2003$.

\subsection{Landfill Gas Generation}

Modern landfills are installed with a cover soil to prevent waste dispersal, minimize the volume of leachate seeping in through the cover and promote the anaerobic degradation of organic waste. The anaerobic decomposition of landfilled waste generates large amounts of gas, typically composed of $55-60 \% \mathrm{CH}_{4}$ and $40-45 \% \mathrm{CO}_{2}$ (Scheutz et al., 2009) and trace amounts of nitrogen, hydrogen sulfide and non-methane hydrocarbons. Methane emissions 
are a significant contributor to global warming, while carbon dioxide formed inside landfills and released into the atmosphere account for a negligible effect compared to other anthropogenic $\mathrm{CO}_{2}$-sources (Huber-Humer et al., 2009).

Figure 2 presents the different phases of landfill gas generation. In Phase I, organic compounds undergo aerobic microbial decomposition and the temperature gradually increases. Oxygen is consumed by bacteria until oxygen is depleted (Phase II), at which stage anaerobic bacteria develop. In Phase III, nitrogen becomes depleted, anaerobic conditions are established and the breakdown of heavy compounds begins through hydrolysis, followed by a conversion into free fatty acids. Phase IV is the methanogenic phase, in which methanogenic bacteria become predominant, converting acids and hydrogen into methane and carbon dioxide. This is the longest phase, drawing to an end (Phase V) as methane and carbon dioxide concentrations begin to reduce and some nitrogen returns to the system, slowly transitioning to stabilization where all anaerobic decomposition is complete and gas in the landfill is primarily air.

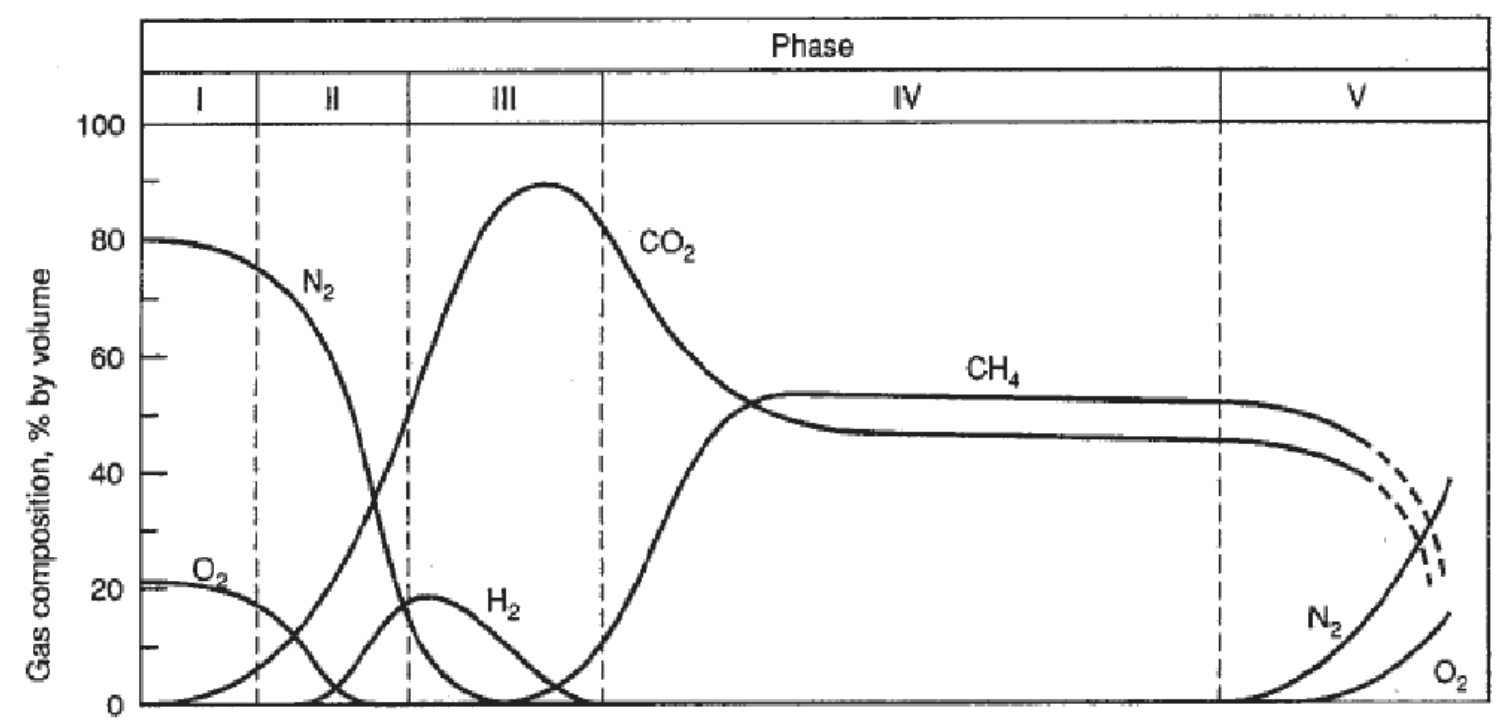

Figure 2 Generalized phases in generation of landfill gases (I-initial adjustment, II-transition phase, III-acid phase; $I V$ - methane fermentation, $V$ - maturation phase) (Tchobanoglous et al., 1993).

According to the type of landfilling technologies used, the amount and type of biodegradable waste and degradation conditions in the landfill, gas is generated in significant amounts over a time span of two to three decades, during and after the operation phase of the landfill (Huber-Humer et al., 2009). Although in much lower quantities after the initial phases, methane can continue to be generated for several decades. The treatment of landfill gas is therefore a problem to be addressed not only during the operation period of the landfill but also after closure of the site, i.e. during the aftercare phase.

Gas generation varies greatly for individual landfills and is dependent on a number of sitespecific operational conditions such as waste type and quantity, organic content of waste, waste age, landfilling technique and daily cover, and site-specific meteorological conditions such as precipitation, atmospheric pressure, $\mathrm{pH}$ and temperature. There is furthermore the possibility of periodical carbon "washing" after heavy rainfall, i.e. when organic matter or 
$\mathrm{CO}_{2}$ dissolves in runoff water that seeps through the cover and into the waste mass, flushing downward with the movement of the leachate.

In reality, the transformation of degradable material in the landfill to $\mathrm{CH}_{4}$ and $\mathrm{CO}_{2}$ is by a chain of reactions and parallel reactions. However, laboratory and field observations on $\mathrm{CH}_{4}$ generation suggest that the overall decomposition process can be approximated by first order kinetics (IPCC, 2006). Landfill generation is typically modelled based on first-order gas generation equations (Scharff and Jacobs, 2006), see Chapter 2.6.1.

\subsection{Gas Transport in Soil and Emissions}

Landfill gas generation creates pressure and concentration gradients between the anaerobic zone and the atmosphere. This leads to advective and diffusive gas transport, respectively, from the waste, through the cover soil and to the atmosphere. Advection can also be induced by a change in barometric pressure (Christophersen and Kjeldsen, 2011; Christophersen et al., 2001, Gebert and Gröngröft, 2006) or by wind. Gas extraction systems could also affect pressure gradients within the landfill. Daily or hourly changes in atmospheric pressure or water content due to precipitation can furthermore result in high temporal variability in $\mathrm{CH}_{4}$ concentrations and fluxes (e.g. Gebert et al., 2011a).

In landfills with no collection systems and thus a pressure build up within the waste mass, it can be assumed that gas transport is dominated by advection. In a setting where little or no pressure gradients are created, gas transport by diffusion can be assumed.

The diffusion process is the result of concentration gradients between the waste layer and the cover soil. When passing through the cover soil, methane must pass through gas and liquid phases depending on the soil conditions. This can highly influence the diffusion rate, since molecular diffusion is approx. $10^{4}$ times slower in water than in air (Cabral et al., 2004).

The composition and distribution of both waste and cover soil is inevitably heterogeneous. This results in high spatial variability of $\mathrm{CH}_{4}$ concentrations and fluxes across the cover soil (e.g. Röwer et al., 2011). Landfill gas can also escape through preferential flow paths such as cracks, holes or vents (Schroth et al., 2012), and be emitted directly to the atmosphere. Cracks can form due to desiccation of the top soil during dry periods, and the presence of roots and vegetation can in some cases create preferential pathways for gas migration.

Landfill gas may also be stored temporarily in the soil cover, e.g. in pores or dissolved in water, until equilibrium is reached (Huber-Humer et al., 2009). All in all, the $\mathrm{CH}_{4}$ mass balance in a landfill can be described using the following relationship (Bogner \& Spokas, 1993):

$\mathrm{CH}_{4}$ production $=\mathrm{CH}_{4}$ recovered $+\mathrm{CH}_{4}$ emitted + Lateral $\mathrm{CH}_{4}$ migration $+\mathrm{CH}_{4}$ oxidized $+\Delta \mathrm{CH}_{4}$ storage $\left[\mathrm{MxT}^{2}\right]$

Lateral migration of landfill gas is well known when coarse cover materials are saturated, limiting diffusive $\mathrm{CH}_{4}$ flux to the atmosphere and developing high internal gas pressures that drive advective flux (Kjeldsen \& Fischer, 1995; Scheutz et al., 2009). Short-term variations in barometric pressure can also drive lateral migration. 


\subsection{Methane Emission Mitigation}

\subsubsection{Extraction, Flaring and Utilization}

Biogas utilization is an option whenever economically feasible. Implementing active landfill gas extraction systems using vertical wells or horizontal collectors, with the intention of flaring or producing energy, is the most important mitigation measure to reduce emissions (Bogner et al., 2007). $\mathrm{CH}_{4}$ generates electricity using internal combustion engines, gas turbines or steam turbines. When the quality of landfill gas is too poor (low methane content), when gas generation rates are low or when site conditions are unfavourable (e.g. shallow cells), flaring of the biogas is used to mitigate emissions. In these cases, $\mathrm{CH}_{4}$ is thermally oxidized into $\mathrm{CO}_{2}$.

The efficiency of gas recovery systems is typically $50-60 \%$ (Börjesson et al., 2007). As reviewed by Scheutz et al. (2009), high recovery efficiencies, i.e. up to $98 \%$, have been reported in modern landfills designed with state-of-the-art methane controls including a lowpermeability liner and low-permeability cover. In a Swedish study on seven landfills, Börjesson et al. (2009) reported recovery efficiencies in ranges of $28 \%-78 \%$ or a mean recovery efficiency of $51 \%$.

At smaller sites or at landfills with less efficient or partial gas extraction systems, there are fugitive emissions both during and after the operation phase, resulting in low total recovery efficiencies for the entire lifetime of the landfill. Measures applied to improve overall gas collection include frequent monitoring and remediation of edge and piping leakages, installation of secondary perimeter extraction systems and frequent inspection and maintenance of cover materials (Bogner et al., 2007).

\subsubsection{Aerobic Landfills}

One method of preventing methane emissions from landfills is the injection of oxygen into the waste mass, i.e. the aeration of the waste mass. The aeration leads to an enhanced aerobic degradation of the landfilled waste, also referred to as aerobic in-situ stabilization. Several municipal waste landfills and old deposits have used this method successfully, such as the old Kuhstedt and Amberg-Neumühle landfills in Germany and other landfills in Italy and the Netherlands.

By means of convection and diffusion, the waste is aerated between injection wells. Suction is applied to other gas wells in order to avoid lateral gas migration or emissions from the surface. This waste gas typically consists of low methane concentrations $(<2,5 \%$ by volume $)$ and is usually treated by thermal oxidation or by biofilters (Ritzkowski \& Stegmann, 2007).

\subsection{Microbial Methane Oxidation}

\subsubsection{Methanotrophic Bacteria}

When landfill gas passes through the top cover, indigenous aerobic methanotrophic bacteria consume $\mathrm{CH}_{4}$ as a source of carbon and energy. These microorganisms have been reported to oxidize from negligible to $100 \%$ of the $\mathrm{CH}_{4}$ generated in the landfills to $\mathrm{CO}_{2}$ (e.g. Börjesson et al., 2007, Scheutz et al., 2009), and it has been observed that they are also able to consume non-methane organic compounds (Scheutz \& Kjeldsen, 2005). 
Two main groups of methanotrophic bacteria exist, type I and type II, differing in the their pathways for carbon assimilation and in morphology (Börjesson et al., 2004). Shifts in methanotroph populations have been observed in response to environmental stimuli (Hanson and Hanson, 1996). In a review of a number of studies on the subject (Scheutz et al., 2009), type II methanotrophs have been predominant in conditions of high $\mathrm{CH}_{4}$ concentrations and scarcity of $\mathrm{O}_{2}$, while type I seem to be best adapted to growth in low $\mathrm{CH}_{4}$ concentrations and high $\mathrm{O}_{2}$ concentrations, i.e. near atmospheric concentrations. It has also been suggested that type I methanotrophs might reflect pioneer species in younger systems with a potentially high growth rate (Jugnia et al., 2009).

\subsubsection{Oxidation Kinetics and Factors of Influence}

Aerobic microbial oxidation of $\mathrm{CH}_{4}$ occurs wherever $\mathrm{CH}_{4}$ and $\mathrm{O}_{2}$ are present simultaneously, and proceeds according to the following reaction:

$$
\mathrm{CH}_{4}+2 \mathrm{O}_{2} \rightarrow \mathrm{CO}_{2}+2 \mathrm{H}_{2} \mathrm{O}+\text { heat }
$$

where $\Delta \mathrm{G}^{\circ}=-780 \mathrm{~kJ} \mathrm{~mol}^{-1} \mathrm{CH}_{4}$ (Hanson and Hanson, 1996). The complete pathway for microbial oxidation involves however intermediate steps where methanol $\left(\mathrm{CH}_{3} \mathrm{OH}\right)$, formaldehyde $(\mathrm{CHOH})$ and formate $(\mathrm{CHOOH})$ are produced by bacteriological conversion.

$\mathrm{CH}_{4}$ oxidation is typically qualified in terms of $\mathrm{CH}_{4}$ oxidation rate $\left(\mathrm{g} \mathrm{CH}_{4} \mathrm{~m}^{-2} \mathrm{~d}^{-1}\right.$ or $\mathrm{g} \mathrm{CH}_{4}$ $\left.\mathrm{m}^{-2} \mathrm{~h}^{-1}\right)$ or $\mathrm{CH}_{4}$ oxidation efficiency ( $\% \mathrm{CH}_{4}$ oxidation). The oxidation rate is defined as the difference between the methane flux entering and leaving the top cover. The oxidation efficiency is an inverse function of the methane emission, since at lower rates, methanotrophic bacteria in the top cover can consume a larger portion of the methane delivered to them. Conversely at higher rates, once an oxidation limit is reached, increasing the delivery of $\mathrm{CH}_{4}$ to the soil does not continue to increase the rate of oxidation and it would appear that the methanotrophic community is limited e.g. by oxygen or microbial population (Chanton et al., 2011).

The microbial oxidation process is sensitive to many factors related to the soil texture and meteorology; including temperature, $\mathrm{pH}$, water content, barometric pressure, methane loading and nutrient levels (Chanton et al., 2011), many of which are interrelated. Some of these factors are briefly reviewed below.

Several studies have examined the effect of different soil moisture levels on methane oxidation, as reviewed by Scheutz et al. (2009), although studies on the effect of water content changes in low temperature environments are scarce. Moisture is essential to sustain microbial activity, i.e. to transport nutrients and remove residual metabolic compounds. Too much moisture, however, slows down gaseous processes as water increases the tortuosity of the pore system and alters gas pathways and because molecular diffusion in water is about $10^{4}$ times slower than in air (Cabral et al., 2004). It can also lead to lateral advective gas migration to areas with lower flow resistance, resulting in emissions or even a pressure buildup adjacent to the landfill, creating an explosive hazard such as occurred in Denmark in 1991, when a gas explosion occurred in a house close to the Skellingsted landfill (Kjeldsen \& Fischer, 1995). To sum up, if the soil is too dry, the activity of methanotrophic microorganisms is inhibited, and if the soil is too wet, the slow diffusion of oxygen can limit their activity. 
All in all, the soil pore volume seems to be a critical factor in the oxidation process since it governs the availability for gas exchange at different moisture contents. Soils that are capable of sustaining sufficient moisture content and at the same time a high share of coarse pores throughout the depth of the cover are therefore favourable. A deep influx of atmospheric air is also advantageous, allowing oxidation to occur at a depth where the soil layer is at more stable moisture and temperature conditions than at the surface and less subject to drying from wind or solar radiation.

Temperature has been observed to have a selective effect in determining which of the two main types of methanotrophs (type I or type II) will predominate in a given system. Low temperatures seem to favour the development of type I methanotrophs (Börjesson et al., 2004). In many studies, optimum temperatures for the promotion of methane oxidation range from about $25^{\circ} \mathrm{C}$ to $35^{\circ} \mathrm{C}$, as determined in field or batch assays (Scheutz et al., 2009). In field studies, lower methane emissions have been reported in summer than in winter, although oxidation activity has been recorded at low temperatures (Scheutz \& Kjeldsen, 2004), even at temperatures right above freezing point (Christophersen et al., 2000; Einola et al., 2007). Soil microorganisms are active at even subzero temperatures because soil particles maintain liquid water films at temperatures down to $-10^{\circ} \mathrm{C}$ (Price and Sowers, 2004).

Pressure changes have been negatively correlated with methane emissions (e.g. Kjeldsen, 1996, Gebert \& Gröngröft, 2006). Other factors have been studies to some extent in many studies, but there is scarce information on methane oxidation and regulating factors in boreal climates.

\subsubsection{Passive Methane Oxidation Biosystem (PMOB)}

A number of different "biosystems" make use of the methane oxidation process, e.g. biofilters, biowindows, biotarps and biocovers, each depending on substrate available and needs of different sectors. Commercially, biocovers and biofilters are considered among the most efficient systems for the mitigation of methane emissions (IPCC, 2007).

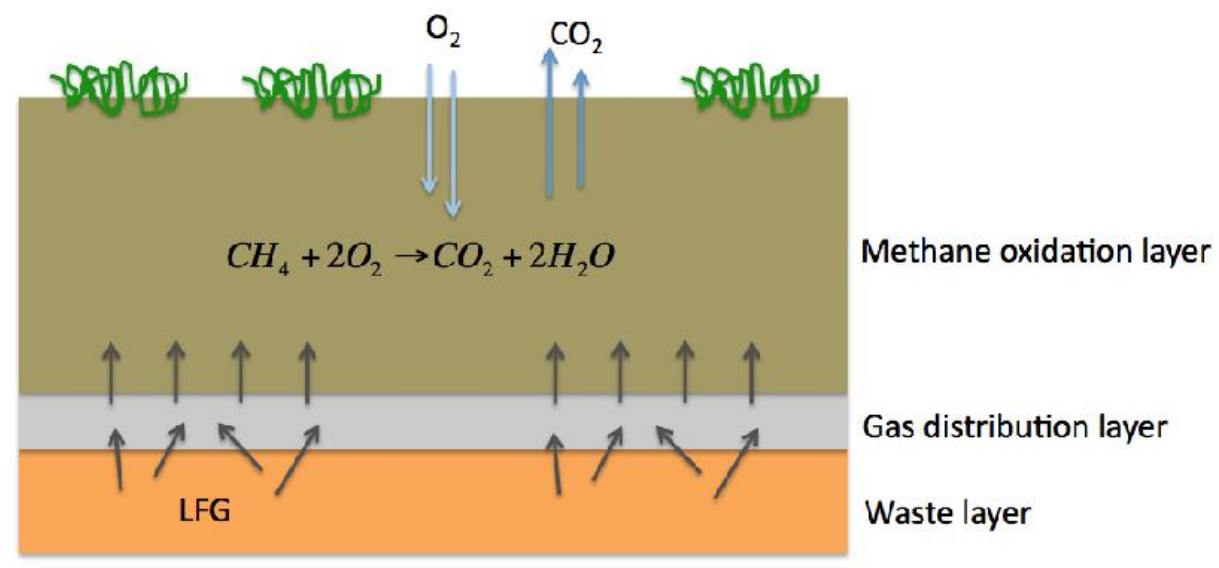

Figure 3 Configuration of passive methane oxidation biocover (PMOB). Landfill gas (LFG) generated in the waste layer goes through a gas distribution layer $(G D L)$ of very porous material and then through a methane oxidation layer (MOL) of an adequate substrate. 
A biosystem is a landfill cover system designed to optimize biotic $\mathrm{CH}_{4}$ consumption. Biosystems typically consist of a coarse gas distribution layer (GDL) to balance gas fluxes placed beneath an appropriate substrate layer, i.e. a methane oxidation layer (MOL), see Figure 3. This substrate is designed to support methanotrophic populations that consume $\mathrm{CH}_{4}$ for carbon and energy.

If environmental variables such as $\mathrm{pH}$ and nutrient status are not limiting, see Chapter 2.5.2, the system performance is suggested to be governed by the share of pores available for gas transport, enabling the supply of atmospheric oxygen to the methanotrophic community. Soil compaction decreases porosity, especially the availability of wide coarse pores $(>50 \mu \mathrm{m}$ diameter), which predominantly controls gas transport (Gebert et al., 2011c).

The coarse gas distribution layer (GDL) of a biosystem overlain by a finer oxidizing layer (MOL) can also serve as an evapotranspirative cover or a capillary barrier, inhibiting the infiltration of water. A capillary barrier is a sealing system that has increasingly been accepted in the last years as a landfill capping, used to prevent emissions and reduce the accumulation of leachate. It consists of a coarse material layer overlain by a layer of fine material. The sealing effect is based on capillary forces that retain water in the soil in the fine material-layer, limiting percolation into the waste mass (Parent \& Cabral, 2006). At the bottom of a slope, however, the accumulation of water can prevent atmospheric $\mathrm{O}_{2}$ from penetrating into the soil, impeding the oxidation process.

A wide range of substrate materials has been tried in laboratory and field studies, including natural soils and compost. It has generally been observed that high oxidation capacity is associated with materials that are porous, coarse and in many cases rich in organic matter (Scheutz et al., 2009). The use of compost alone or other high organic content materials may however not be ideal in biosystems, since the material can undergo significant compaction over time and can become easily saturated, inhibiting the influx of atmospheric air and impeding the oxidation process (Jugnia et al., 2008). Scheutz et al. (2009) reviewed a number of studies using sandy soils with moderate organic content (2-5\%) that exhibit high oxidation rates. High oxidation can furthermore occur in vegetated soil covers (Abichou et al., 2006), since vegetation can control moisture infiltration and thus perhaps enhance biotic $\mathrm{CH}_{4}$ uptake. It has been indicated that about $90 \%$ of the annual precipitation may be retained in or evapotranspirated by a well designed vegetated biosystem in temperate climates, i.e. 500$1000 \mathrm{~mm}$ rainfall (Huber-Humer \& Lechner, 2003).

Biowindows are essentially the same as biocovers, only landfill gas leaving the cover is concentrated on a small surface, requiring a higher oxidation capacity of the substrate material used. Biofilters are similar to the biowindow, only more mechanical, requiring a steady supply of landfill gas and typically connected to an existing piping system.

\subsection{Quantification and Estimation}

In view of the complex gas transport mechanisms and methane consumption for individual landfills and both temporal and spatial variability of landfill gas generation, there is no single perfect technique that can be recommended to obtain precise measurements or for practical application. Each method has its strengths and weaknesses. The following text sums up some of the main methods and techniques used to estimate methane generation, emissions and oxidation. 


\subsubsection{Methane Generation Estimation}

There is no scientifically accepted method to measure methane production. Landfill gas generation is therefore typically estimated through models, using available data on age of waste, its type and quantity, and measurements of methane concentrations in the waste layer. A number of models on landfill gas generation exist, such as the IPCC model from the National Greenhouse Gas Inventories Programme of the IPCC, LandGem, GasSim and the Afvalzorg models, to name only a few, using different degradation rates, dissimilation factors, lag times and conversion factors.

A comparison of different models has shown an enormous difference in results (Scharff and Jacobs, 2006), also when compared to whole site emission measurements. None of the models are therefore considered very reliable but can give a good idea of the gas generation if good data is available, i.e. annual waste inventories on waste quantities and waste type. Indeed, in the 2006 guidelines, higher tier methods are encouraged, applying field measurements to be scaled up to regional or national levels. In terms of $\mathrm{CH}_{4}$ oxidation, higher tier methods take into account seasonal climatic variability and site conditions, which in the future with better measurement techniques will be an important improvement over the use of default values.

\section{IPCC model}

The IPCC model uses a multicomponent First-Order-Decay (FOD) method for estimating emissions of methane from landfills (IPCC, 2006). The method assumes that degradable organic matter in the waste (degradable organic carbon, DOC) decays slowly over the course of a few decades, during which $\mathrm{CH}_{4}$ and $\mathrm{CO}_{2}$ are formed. Under steady state conditions, the production depends solely on the amount of carbon remaining in the waste. As a result, landfill gas emissions are highest in the first few years after deposition and then gradually decline as degradable carbon is being consumed.

The FOD method uses a first-order kinetic equation to partition $\mathrm{CH}_{4}$ generation over the years after waste placement, based on a chosen kinetic constant $\mathrm{k}\left(\mathrm{t}^{-1}\right)$ and the gas potential for various waste fractions $\mathrm{L}_{0}\left(\mathrm{~m}^{3} \mathrm{LFG}\right.$ per $\mathrm{m}^{3}$ waste) (IPCC, 2006). The IPCC model makes use of an estimated Methane Correction Factor, MCF, which is based on measured $\mathrm{CH}_{4}$ concentrations in the landfill gas, calculated using the equation (3.1);

$$
M C F=\frac{\% \mathrm{CH}_{4}}{0,5}
$$

If the methane concentration of landfill gas is higher than $0,5(50 \%)$, then $\mathrm{MCF}=1$. Waste inventories are used to allocate annual waste quantities into 9 waste categories; Food, Garden, Paper, Wood, Textile, Nappies, Sludge, Inert and Industrial. The IPCC model is used to estimate gas generation at cell 2 of the Fíflholt landfill, see Chapter 5.5.

\subsubsection{Methane Emission Estimation}

A number of methods have been developed to quantify $\mathrm{CH}_{4}$ fluxes from landfill cover soils to the atmosphere and estimate total emissions. The most important techniques today are static and dynamic chamber measurements, micrometeorological measurements and static and dynamic plume measurements. All of these methods have their limitations, the main 
problem being the inability to account for highly heterogeneous emissions from a landfill, both temporally and spatially. The parallel use of two or more methods is therefore highly recommended (Scheutz et al., 2009).

\section{Chamber measurements}

Chamber-flux measurements are among the most commonly used methods to quantify $\mathrm{CH}_{4}$ fluxes from landfill covers (Abichou et al., 2006; Scheutz et al., 2009; Trégourès et al., 1999). The technique is relatively simple and results can be visualized using GPS coordinates. Two types of flux chambers are utilized in the field, static and dynamic flux chambers, described below.

Static flux chambers are relatively inexpensive, easy in operation and can detect very small fluxes (Schroth et al., 2012). A sampling device typically consists of a box with a relatively small surface area, in which an increase in $\mathrm{CH}_{4}$ concentration in time is measured. Boxes or "chambers" are typically in the range of $0,25-1 \mathrm{~m}^{2}$, but there have been trials with even larger chambers.

Dynamic flux chambers resemble static flux chambers except for one aspect: a continuous air-flow is maintained in a dynamic chamber, avoiding the build up of concentrations, pressure and influence of fluxes within the chamber. This makes the dynamic flux chamber far superior to the static flux chambers, since there is no pressure build-up, which could influence the flow of gas directly below the chamber.

Flux chambers can however only be used for short periods to minimize disturbances of the surface measured, hence do not take into account the temporal variability of fluxes observed in many studies (e.g. Rachor et al., 2009). Accounting for temporal variability would require measurements on several days throughout the year or even many times during the same day (Gebert et al., 2011a).

Furthermore, the variation between chamber measurements is large due to the spatial variability of landfill gas fluxes that can range over more than seven orders of magnitude, from $<0.0001$ to $>1000 \mathrm{~g} \mathrm{CH}_{4} / \mathrm{m}^{2} / \mathrm{d}$ (Bogner et al., 1997). Many measuring points are therefore required to allow scaling up to a larger area and prevent either over- or underestimation of emissions. This can prove both laborious and expensive in practice. High emission areas on the landfill cover, i.e. "hot spots", may be qualitatively identified using a portable flame ionization detector (FID) that detects methane concentrations at the top of the cover. These hot spots can however easily be missed, resulting in an underestimation of flux values.

\section{Micrometeorological measurements}

Micrometeorological techniques are based on the measurement of gas concentration gradients and meteorological parameters at different heights above ground level, through an imaginary vertical plane. These can be automated, mounted on towers with fast-response sensors, and cover wide areas, making the method suitable for larger surfaces. The size of the footprint area depends on the measurement height, atmospheric stability and wind speed (Lohila et al., 2007). There are some limitations to this method however, as the landfill surface should be uniform and continuous, preferably flat (Huber-Humer et al., 2009), and it is sensitive to wind direction. Highly sophisticated and sensitive equipment is required to 
measure gas concentration and determine meteorological data, and the method involves complex calculations and modelling for a reliable quantification of vertical gradients.

\section{Plume measurements}

One alternative for quantifying whole-landfill emissions is using downwind plume concentration measurements, dynamic or stationary. This is combined with meteorological data and dispersion modelling, which can also be avoided if using a reference release system, i.e. a tracer with a known release rate. On-site point sources can also be quantified using a double tracer technique, helpful to identify high emission areas within the landfill (Scheutz et al., 2011).

Dynamic plume measurements, involves measuring the difference in methane fluxes through a transect screen downwind and upwind from the landfill. Emissions are typically assessed comparing methane concentrations with tracer concentrations, where a specific tracer gas is released upwind at a known rate. The method estimates emissions for the whole landfill, accounting for spatial variability, i.e. it can capture methane emissions from the soil cap including point sources such as cracks and holes or vents not covered by e.g. the chamber method. It can also differentiate between different sources of methane by using the tracer.

Concentration detection requires however highly sensitive techniques, e.g. Fourier transform infrared (FTIR) spectroscopy or thermal diode laser (TDL), which are expensive and not easy to come by. Due to the high cost, the method is typically only applied for one or a few days, while ideally measurements would have to be carried out at different times throughout the year to account for temporal variation. Simpler measurement techniques with more costeffective instruments have however been developed recently with success e.g. in Denmark

Stationary plume measurements involve collecting air samples downwind of the landfill during a period of time and using a dispersion model to obtain the concentration variation with time at the location of measurement. This method is often coupled with the stable isotope method, described in Chapter 2.6.3. The source strength causing the plume is then estimated through modelling, providing an emission estimate for the whole landfill. The method requires less manpower than many other methods since sampling does not need attendance and can be carried out for longer times, taking temporal and spatial variation of emissions into account (Scharff and Jacobs, 2006). The technique however requires a purpose-based development in the initial stages, i.e. for calibration, modelling and quantification, to obtain reliable emission results. This is elaborate, time consuming and expensive (Scharff and Jacobs, 2006).

Drawbacks to plume measurements, static and dynamic, are that greenhouse gases are often released as tracers, e.g. $\mathrm{SF}_{6}$ or $\mathrm{N}_{2} \mathrm{O}$, contributing to the greenhouse effect if a long-term continuous monitoring strategy is applied (Humber-Humer et al., 2009). In Denmark, an acetylene tracer is used (Mønster, 2012, personal communication) for research purposes, which is non-toxic but flammable like methane. Like the meteorological method, plume methods are difficult to apply in variable topography with high or variable wind speeds, where plumes can be missed.

\subsubsection{Methane Oxidation Estimation}

In order to accurately estimate the efficiency of biosystems, knowledge of the influx or methane load to the biosystem is required (Huber-Humer et al., 2009). This data can however 
rarely be acquired. Often, for research purposes, methane fluxes are controlled or supplied to test cells over a small area to enable calculation of oxidation rate with relative ease (Roncato \& Cabral, 2012).

The oxidation capacity of cover materials is often sampled in batch or flow-column set-ups under controlled laboratory conditions, using the methods described below. Since only small samples are studied at a time, lab or batch trials may only be representative for homogeneous materials, which is rarely the case in landfills. Furthermore, laboratory tests often highly overestimate the oxidation capacity in field application, since optimal conditions are created in the lab that are can never resemble true meteorological conditions in the field, and the sampling procedure often alters physical properties of the soil, increasing its porosity and thus increasing microbial activity (Huber-Humer et al, 2009).

\section{Gas Profile method $\left(\mathrm{CH}_{4} / \mathrm{CO}_{2}\right.$ ratio method)}

Measuring the $\mathrm{CH}_{4}, \mathrm{CO}_{2}$ and $\mathrm{O}_{2}$ concentrations of gas samples collected along a vertical profile in a cover soil, it is possible to estimate the depth of the zone where $\mathrm{CH}_{4}$ oxidation is occurring and qualitatively assess the oxidation, i.e. the cumulative oxidation efficiency in the profile. This method has usually been used supportively in parallel with other measurements, but has recently been proposed as a stand-alone method to assess microbial oxidation in landfill covers (Gebert et al., 2011). The method is furthermore simple and inexpensive in execution, demanding only probe installation and periodical gas concentration measurements. This method, which is the basis for the present study, and assumptions made for its use is explained in more detail in Chapter 3.4.

The method is independent of the nature of gas transport mechanisms in the soil, whether advective or diffusive, and assumes that $\mathrm{CH}_{4}$ and $\mathrm{CO}_{2}$ are diluted to the same extent in the soil pore volume. It has been used in both laboratory studies (batch and column) and in the field and the approach has been validated using mass balance data from two independent laboratory column experiments (Gebert et al., 2011).

Several interfering processes should be taken into account when adapting the $\mathrm{CH}_{4} / \mathrm{CO}_{2}$ method to any estimation, e.g. microbial respiration, particularly in soil material with high organic matter, carbon fixation in methanotrophic biomass during population growth and temperature-dependent solubility of $\mathrm{CH}_{4}$ and $\mathrm{CO}_{2}$ in water, $\mathrm{CO}_{2}$ being more soluble than $\mathrm{CH}_{4}$. The problem might be even further exacerbated with the presence of vegetation or plants with established root systems or if engineered gas recovery systems are installed in the landfill.

In a well-established top cover, respiration is of particular concern, especially in covers with high organic matter content. Respiration, however, also seems to be dependent on the $\mathrm{CH}_{4}$ oxidation rate, since the share of respiratory $\mathrm{CO}_{2}$ release decreases exponentially as the oxidation rate increases (Gebert et al., 2011).

In theory, methane emissions from the top cover can be estimated from $\mathrm{CH}_{4}$ vertical profiles if combined with estimated gas transport properties of $\mathrm{CH}_{4}$, i.e. the effective diffusion coefficient of the cover material. The diffusion coefficient, not discussed here in detail, is however very dependent on soil and environmental factors such as available air-filled pore volume and water content, making these estimations at best very approximate, either highly over- or underestimating real fluxes. Gas profiles have therefore thus far only been used as 
a qualitative indicator of methane oxidation, not quantitative, and to localize the approximate depth of the methane oxidation.

\section{Mass balance method}

Oxidation efficiencies can be estimated using the mass balance method, which is based on the gas flux of a specific compound in and out of a substrate, the flux being defined as the quantity of gas passing through a surface at a certain time interval. This method typically requires the control of gas flux into a soil cover, where lateral gas diffusion is prevented by insulation of the sides. The efficiency can be calculated using the following equation (Gebert et al., 2011)

$$
E f f_{o x}=\frac{\left(\text { flux }_{\text {in }}-\text { flux }_{\text {out }}\right)}{\text { flux }_{\text {in }}} \times 100
$$

where Effox is the oxidation efficiency (\%), and flux ${ }_{\text {in }}$ and flux out $_{\text {ou }}$ is the flux ( $\mathrm{ppm} / \mathrm{s}$ or $\mathrm{g} / \mathrm{m}^{2} /$ day), in and out of a given surface or body. Under controlled circumstances, the influx can be controlled through a feeding system. The flux from the surface can be measured using chamber techniques.

Much like the $\mathrm{CH}_{4} / \mathrm{CO}_{2}$ method, the mass balance method is problematic since other processes such as soil respiration also produce $\mathrm{CO}_{2}$. This method is therefore not recommended for field settings and only for controlled laboratory settings.

\section{Stable Isotope method}

Several methods have been applied to identify the density and composition of methanotrophic population and estimate its activity, e.g. enumeration methods (conventionally the MPN method), Fluorescent In Situ Hybridisation (FISH) method and specific diagnostic micro-arrays (Huber-Humer et al., 2009).

Stable isotopes have been used in recent years to determine methane oxidation in landfill covers. There are two stable isotopes of carbon, ${ }^{13} \mathrm{C}(1 \%$ abundant $)$ and ${ }^{12} \mathrm{C}(99 \%$ of carbon atoms) (Abichou et al., 2006). Methanotrophic bacteria prefer light carbon isotope ${ }^{12} \mathrm{C}$ to ${ }^{13} \mathrm{C}$. The lighter ${ }^{12} \mathrm{CH}_{4}$ is therefore oxidized slightly faster that ${ }^{13} \mathrm{CH}_{4}$ and methane passing through an oxidation zone becomes heavier while carbon dioxide becomes lighter (De Visscher et al., 2004). The stable isotope method thus quantifies methane oxidation by measuring the isotopic ratios of methane emitted at the surface or in the upper $\mathrm{cm}$ of the soil cover, and comparing them to isotope ratios of landfill gas generated inside the waste. Samples can also be taken upwind and downwind of the landfill to find an average of the oxidation over the whole site. To date the method has however displayed several limitations due to an extremely specific fractionation factor $\alpha_{o x}$ for individual methanotrophic populations and their growth conditions (e.g. Cabral et al., 2010). The fractionation factor must be determined specifically for each landfill, which is a laborious and costly process in the laboratory. 


\section{Gas Push-Pull Test}

The gas push-pull test (GPPT) has been developed in recent years (Streese-Kleeberg et al., 2011), where a gas mixture containing $\mathrm{CH}_{4}$ and $\mathrm{O}_{2}$ and inert tracer gases (e.g. Ar, Ne) is injected into the soil. Subsequently, the mixture of injected and soil gases is withdrawn from the same location and sampled periodically. A time dependent devolution of injected concentrations can be related to microbial activity and thus oxidation rates be derived. This is limited by an estimation of spatial resolution, since oxidation can vary greatly within the same landfill based on a number of parameters, see Chapter 2.5.2.

\subsection{Icelandic Climate Conditions}

Iceland is situated in the North Atlantic, just south of the Arctic Circle between latitudes $63^{\circ} \mathrm{N}$ and $66^{\circ} \mathrm{N}$ and longitudes $13^{\circ} \mathrm{W}$ and $24^{\circ} \mathrm{W}$. The solar altitude is never large because of the high latitude, and daytime duration varies greatly between seasons, with very short days in winter and long days and midnight sun in summer (Einarsson, 1984).

The climate in Iceland is typically classified as a cool temperate maritime climate or boreal climate, characterized by long winters and short, cool to mild summers. According to the Köppen classification the climate in Iceland is a mix of Maritime subarctic climate (Dfc) in the lowlands, reflecting its dependency on the ocean waters surrounding the island, and arctic Tundra climate (ET) in the highlands, (Peel et al., 2007). It is situated between warm and cold ocean currents that greatly influence the local climate. The North Atlantic Drift and the Irminger Current, which is a branch of the Gulf Stream, flow along the southern and western coasts, and a cold East Greenland Current and its branch, the East Icelandic Current, flow along the north and northeast coasts (Einarsson, 1984). These different currents result in a climate marked by frequent weather changes, winds and storms. Sea temperatures are typically close to $+2^{\circ} \mathrm{C}$ during the coldest months (January - March) and rise to over $+10^{\circ} \mathrm{C}$ at the south and west coasts during the summer.

The annual mean temperature in western Iceland is typically $2-4^{\circ} \mathrm{C}$, but can reach $4-6^{\circ} \mathrm{C}$ along the coasts of southern and southwestern Iceland. Icelandic winters are relatively mild for the country's latitude, and its summers are cool. The mean temperature of the warmest month, July, is $10-12^{\circ} \mathrm{C}$ in the area, but it is typically lower in other parts of the country. During the coldest month, January, the average temperature in the area is typically $-1-2^{\circ} \mathrm{C}$, but the temperature is considerably lower in the highlands and in the northern parts of the country (Einarsson, 1984). At Stykkishólmur, which is situated at the coast not far from the location of the present study, the annual mean temperature has ranged from 4.3 to $5.4^{\circ}$ between $2003-2013$, from $11-12^{\circ} \mathrm{C}$ in the summer months down to $-2-0^{\circ} \mathrm{C}$ in the winter months (IMO, 2013).

Iceland has the most extensive area of Andosols (volcanic soils) in Europe (Arnalds \& Óskarsson, 2009). These soils are highly fertile despite the harshness of the climate, often with high organic matter content. Soils in Iceland are exposed to annual freeze and thaw cycles between November and May, which are unusually frequent and more than in any other sub-arctic region (Orradóttir et al., 2008). Decomposition processes are therefore complex due to persistent microbial activity at low temperatures and frequent changes in substrate quality. 
Like the ocean currents, warm and cold air masses frequently meet near Iceland, forming disturbances that can intensify and create large pressure variations (Einarsson, 1984). Mean monthly atmospheric pressure values adjusted to sea level, measured at the weather station at Stykkishólmur on the Snæfellsnes peninsula, not far from the Fiflholt landfill which this study is based on, have been in the range of $990-1020 \mathrm{hPa}$ in the last ten years (IMO, 2013). 



\section{Materials and Methods}

In this chapter, the Fiflholt landfill and the gas profile method are presented in detail. The experimental setup, sampling program and measurement techniques are described, and methods used to assess the methane oxidation and calculate the oxidation efficiency presented.

\subsection{Site Selection}

The choice of landfill to study was in part based on the landfill information base collected by Júlíusson (2011) and on the following criteria:

- Landfill receiving municipal solid waste from neighbouring communities, representative of most Icelandic landfills

- Landfilling method representative of most Icelandic landfills and sufficient cell depth to promote adequate methane generation, i.e. at least $4 \mathrm{~m}$ (Kamsma \& Meyles, 2003)

- Landfill with active gas generation representative of the methanogenic phase, i.e. containing waste younger than approximately 20 years and with methane content preferably exceeding $40 \%$ )

- No gas extraction system in place, as is the case with most Icelandic landfills.

- Moderate distance from Reykjavík, i.e. within 150 km or max. 1.5 hour drive away

- Availability of on-site or nearby background meteorological data

The two largest landfills in Iceland are the Álfsnes landfill, serving the capital area in the southwest of Iceland, and the Akureyri landfill (Glerárdalur), which served urban areas in the north of the country and is now closed since early 2011. A gas extraction system, the only one in the country, and a subsidiary biomethane production centre is operated at the Álfsnes landfill, and a gas collection system is currently in construction at the Akureyri landfill. The two next largest landfills in the country are the Fíflholt and Kirkjuferjuhjáleiga landfills, neither with gas extraction systems. The Kirkjuferjuhjáleiga landfill is situated in the south of Iceland, approx. $50 \mathrm{~km}$ east of Reykjavík. It was in operation from 1995 until December 2009, receiving a total of approx. 15,000 - 22,000 tpa (tons per annum). Other landfills are situated farther than $150 \mathrm{~km}$ away and are considerably smaller in size then the ones mentioned above.

The Fíflholt landfill is situated in the west of Iceland, approx. $100 \mathrm{~km}$ north of Reykjavík. It has been in operation since 1999 and currently receives up to 10,000 tpa of waste. It is also one of the largest landfills in Iceland, although small in international comparison. For practical purposes, the Fíflholt landfill was chosen due to its distance from Reykjavík and it still being in operation. Also, a national meteorological station is situated on-site at the Fíflholt landfill, giving accurate information on weather conditions. The Kirkjuferjuhjáleiga 
landfill, however, is no longer in operation and the closest weather station is situated at Eyrarbakki, ca 9 km away, giving slightly less accurate meteorological data.

\subsection{Fíflholt Landfill - Site Description}

\subsubsection{Background and Dimensions}

The Fiflholt landfill was built in 1998 and has been in operation since December 1999. It is located in the municipality Borgarbyggð in Western Iceland, N64 4 , W22 ${ }^{\circ} 1$, just south of the Snæfellsnes peninsula and less than $10 \mathrm{~km}$ from the coast (see Figure 4). The landfill is situated south of the national road in an area with outcrops of Tertiary basalt lava formations dipping eastward., These lavas have very low permeability (VGK Hönnun, 2007). The area is lowland and covered with rivers, wetlands and small lakes. The area was under sea level during the Ice Age and there is the possibility that fine soil materials further reduce conductivity in cavities.



Figure 4 Location of the Fiflholt landfill in Western Iceland [Map: LMÍ].

The landfill is approximately 16ha in size, occupying almost half of the designated landfilling area, see layout in Figure 5. It is run by The Solid Waste Management of the West Iceland Regional Office (is. Sorpurðun Vesturlands) and serves all municipalities in the West of Iceland, including the West fjords since late 2010, or a total of ca 20,000 inhabitants (EFLA, 2012). It currently receives up to approx. 10,000 tpa of waste but can receive up to 15,000 tpa according to its operating license, issued by the Environmental Agency (EAI, 2002). In 2006 it received 12,900 tonnes of waste, but since then recycling has increased, reducing the amount of landfilled waste (SWMWIRO, 2012). 
The site has a permit for all MSW and waste that is not classified as hazardous according to Icelandic regulation no. 806/1999. Slaughterhouse waste was landfilled separately until late 2012, and asbestos insulation material is put in a separate cell. Slaughterhouse waste has decreased in the past years and today accounts for approx. $4 \%$ of total landfilled waste by weight (EFLA, 2012).

An Iceland Meteorological Office meteorological monitoring station is situated at the landfill since 2006. It measures atmospheric humidity, temperature, wind direction, mean 10-minute wind speed, 3 second wind gusts and precipitation. Data is logged every 10 minutes. Local climatological measurements have been logged during permit-related monitoring at Fíflholt and can be found in the annual green accounting for the landfill (SWMWIRO, 2012).

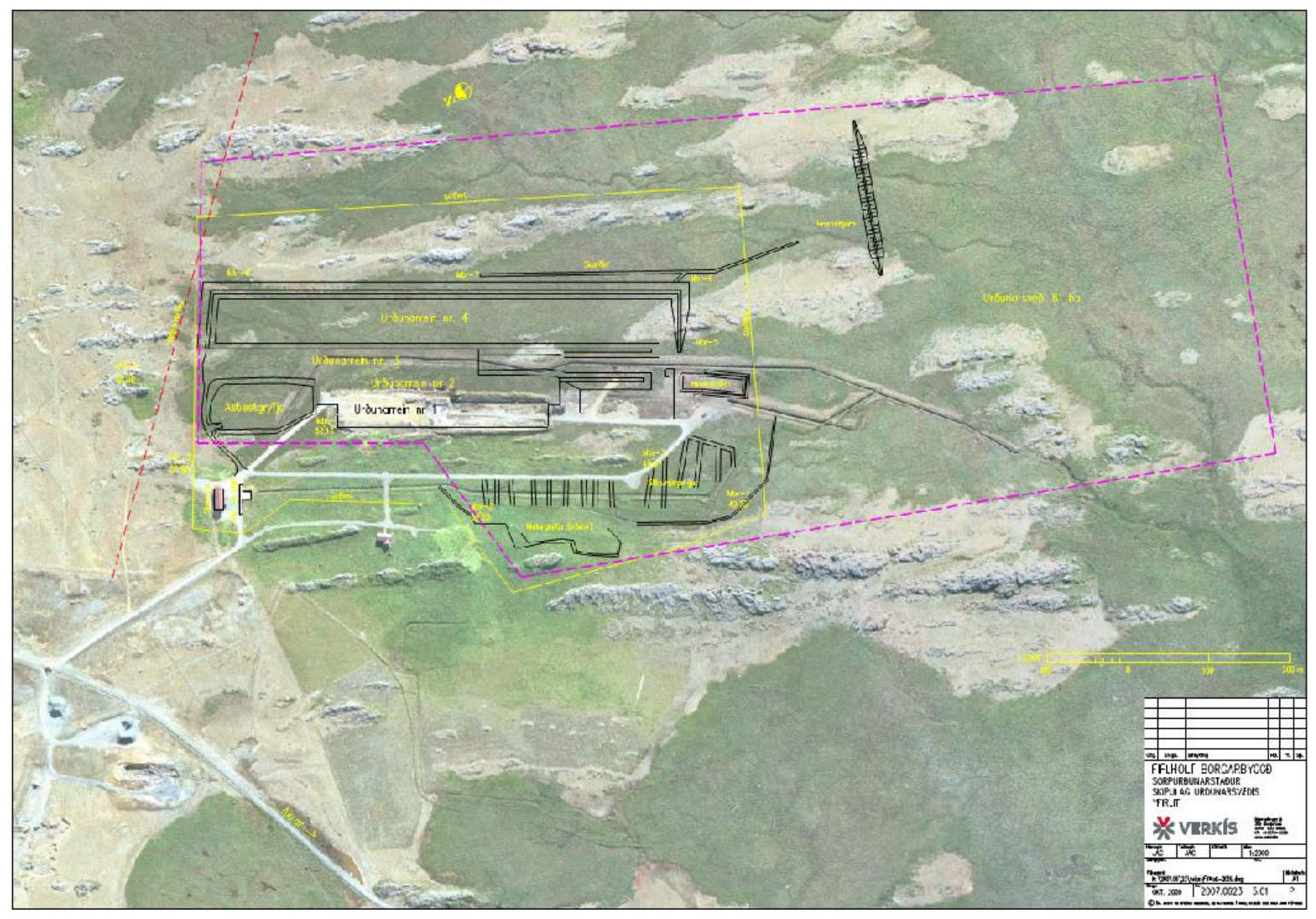

Figure 5 Plan view of the Fiflholt landfill, Borgarbyggð, West Iceland. The black horizontal lines denote the layout of cells 1-4, cell no. 4 being at the top of the figure and cells 1-3 right below. A fence, indicated by the yellow line, surrounds the landfilling area and the purple line denotes the total area reserved for landfilling. (VERKÍS Consulting Engineers).

Leachate at the Fíflholt landfill is drained through a soil filter and then enters the small river Norðlækur which flows into the sea at Akraós. There is no secondary or tertiary, i.e. biological, treatment. Pollutants are regularly monitored from landfill leachate discharge in accordance with the operating license. Samples are taken twice a year for analysis, i.e. point measurements taken once in winter and once in summer. Continuous leachate measurements have not been made. Based on measurements performed 2002-2011 for the site's green accounting, the leachate has the following mean characteristics: flow rate $0.2 \mathrm{l} / \mathrm{sec}$ (from cells 1-3), pH 6.8 and COD $540 \mathrm{mg} / \mathrm{l}$. The $\mathrm{pH}$ levels would indicate that the landfill is in methanogenetic phase and COD levels are low compared to other Icelandic sites with COD ranging from 10 to $4820 \mathrm{mg} / 1$ (Harstad, 2006). 
The groundwater level and weather conditions during sampling are also monitored regularly and reported in the annual green accounting for Fíflholt (SWMWIRO, 2013). According to a risk assessment performed for Fíflholt (EFLA, 2012), more than 95\% of the leachate goes to the collection system and subsequent treatment, i.e. the soil filter, due to the nearly impermeable underlying bedrock.

Three cells, no. 1-3, have now been filled and, early in September 2012, cell no. 4 started to be filled. Cell no. 1 is the smallest and shallowest of the three existing cells, approx. $3 \mathrm{~m}$ deep, cell 2 is 4-5 m deep and cell 3 is approx. $6-7 \mathrm{~m}$ deep (SWMWIRO, 2011). Cell no. 4 has a surface of $50 \mathrm{~m} \times 580 \mathrm{~m}$, depth $7-8 \mathrm{~m}$, and it is the largest to date, approximately the equivalent of the former three put together (SWMWIRO, 2012).

The waste comes mainly in containers and trucks and is dumped into cells and compacted. At the end of each day the waste is covered with approx. $10-15 \mathrm{~cm}$ of crushed wood to prevent the waste from blowing away and to deter birds from getting into the waste. After 2 to 3 days of degradation, the waste is usually moved within the same cell and recompacted. According to site technicians, a better net compaction of the waste mass is achieved this way.

The the top cover of the landfill is $1-1.2 \mathrm{~m}$ thick, composed of $15-25 \mathrm{~cm}$ of crushed wood and approximately $1 \mathrm{~m}$ of excavated soil from the site, see Figure 10. The crushed wood at the bottom of the top cover is thicker than the daily covers, especially in cells 3 and 4, mainly to serve as a biofilter against smell. A thin layer of gravel, coming mainly from nearby river Kaldá has been applied on top of cells 3 and 4 to improve grip for heavy traffic. No such gravel layer was put on top of cells 1 and 2, since the current soil cover was considered sufficient for the traffic load (Eypórsson, 2013, personal communication). All cell covers are flat.



Figure 6 Location of sampling tubes on top of cell 2 at Fiflholt landfill, identified as C2-N and C2-S. Sampling tubes are situated right next to monitoring wells. Coloured lines are explained in Figure 5 [VERKÍS Enginering Consultants]. 
There are two functioning gas-monitoring wells at Fiflholt, installed in 2009 under the commission of The Solid Waste Management of West Iceland Regional Office. These are located at cell 2, see Figure 6, identified as C2-N (Cell 2-North) and C2-S (Cell 2-South), see Chapter 3.3.2. A third monitoring well was also installed at cell 3 but is malfunctioning. Monitoring wells had previously been installed at cell 1 and cell 3 also, but none of them are functioning today. Landfill gas concentrations have been monitored since 2009 in compliance with the operational permit and new requirements of gas monitoring and treatment. A review of recent gas concentration measurements, performed by authorities and by Júlíusson (2011), and measurements performed for this study can be seen in Chapter 3.3.4.

Given the proximity of gas monitoring wells, easy access and sufficient waste age and cell depth to promote methane generation, cell 2 was chosen for research in this study for practical purposes. Cell 2 contains waste from years $2003-2006$, having received a total of 36,000 tons of waste (SWMWIRO, 2004 - 2007), or total 44,000 tons including the chopped wood used as a daily cover. It has a bottom area of $5100 \mathrm{~m}^{2}$ and top flat area of $9000 \mathrm{~m}^{2}$. No vegetation is currently on its surface.

Based on the location of C2-S and $\mathrm{C} 2-\mathrm{N}$, it can be assumed that waste underneath $\mathrm{C} 2-\mathrm{N}$ was approx. 8-9 years old during the period of this study, and that it was approx. 7-8 years old underneath C2-S. The two locations are $105 \mathrm{~m}$ apart and according to site technicians should have identical soil covers, i.e. composition and thickness. According to the landfill's green accounting, some differences can be observed in the waste inventory between the years 2003 and 2006, when cell 2 was being filled. As can be seen in Figure 7, food and paper waste decreased over the course of these years while wood and industrial waste increased considerably (SWMWIRO, 2004 - 2013), see details in Appendix B. The waste mass beneath $\mathrm{C} 2-\mathrm{N}$ and $\mathrm{C} 2-\mathrm{S}$ might therefore be very different, with more biodegradable material beneath $\mathrm{C} 2-\mathrm{S}$.

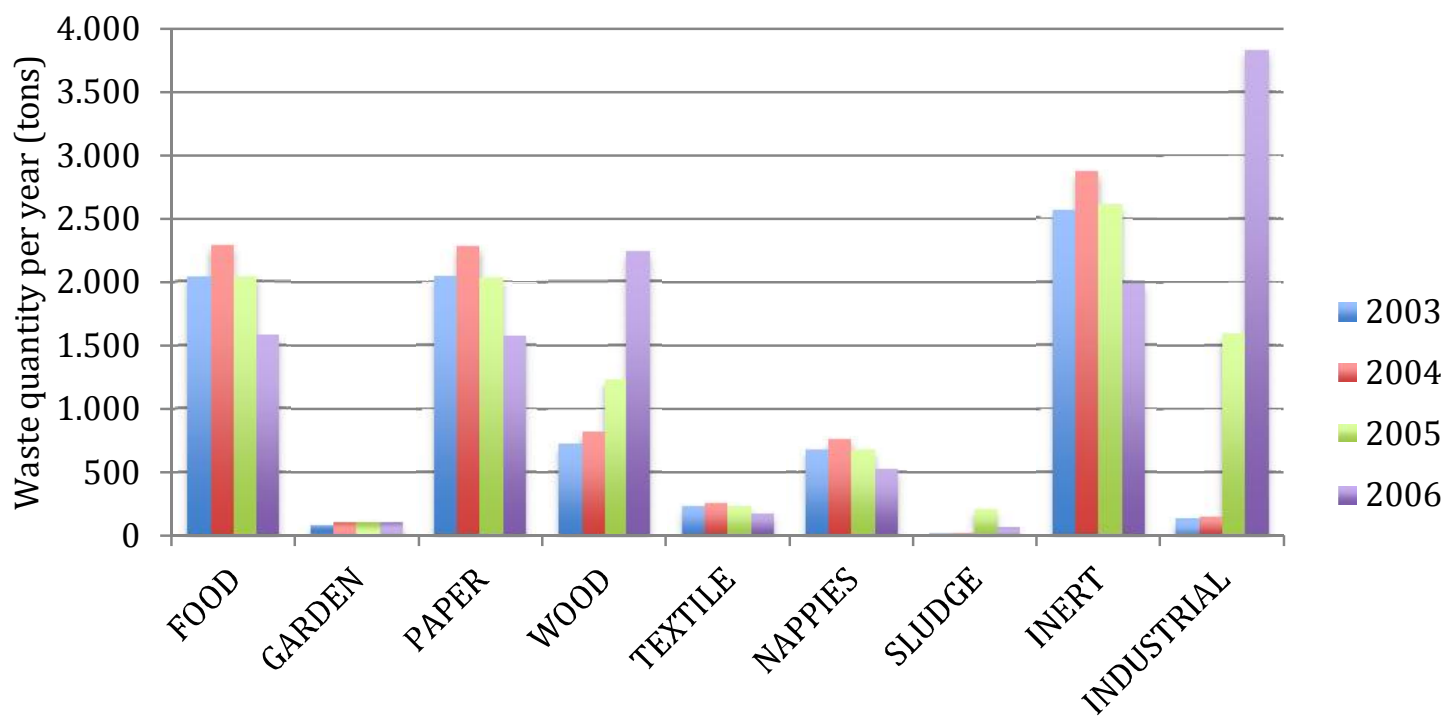

IPCC WASTE CATEGORIES

Figure 7 Annual waste categories and quantities 2003-2006 at the Fiflholt landfill, according to landfill inventories, i.e. when cell 2 was being filled. Cover materials are not included here. A more detailed inventory is presented in Appendix $B$. 


\subsubsection{Local Meteorology}

An Icelandic Meteorological Office weather station has been in operation at the Fiflholt landfill since March 2006. According to IMO data for the period 2006-2011, the annual precipitation at Fíflholt was on average approx. $770 \mathrm{~mm} /$ year (max: $1044 \mathrm{~mm}$, min: 550 $\mathrm{mm})$.

Meteorological information during the time of gas sampling is summarized in Table 1, i.e. mean wind (10 minute), accumulated precipitation ( $24 \mathrm{hrs}, 48 \mathrm{hrs}$ and 7 days), ambient temperature and barometric pressure (sea level). All meteorogical data was obtained from the IMO weather station at Fíflholt, except for the barometric pressure, which was estimated from data from weather stations at Stykkishólmur ( $75 \mathrm{~km}$ northwest of Fíflholt) and Húsafell (70 km east of Fíflholt) during the time of sampling.

Based on available literature on microbial methane oxidation, particular interest was taken accumulated precipitation ( $24 \mathrm{hrs}, 48 \mathrm{hrs}$ and 7 days), atmospheric temperature and pressure, see results in Chapter 4. Data on wind gusts, wind speed and humidity was not examined for the purpose of this study.

The study period covers seven consecutive months, i.e. August 2012 - February 2013, including an eight month, August 2013. On five of the eight months, i.e. from October 2012 to February 2013, low temperatures are recorded, typical of Icelandic winter months. Typical cool summer temperatures are recorded on the three remaining sampling dates, i.e. in August and September 2012 and in August 2013.

Table 1 Local weather conditions during the time of field measurements at the Fiflholt landfill, from August 2012 to August 2013. Mean values during time of sampling. All information obtained from the IMO weather station situated at the Fiflholt landfill, except for atmospheric pressure (adjusted to mean sea level), estimated from weather stations at Stykkishólmur and Húsafell.

\begin{tabular}{|c|c|c|c|c|c|c|c|}
\hline Date & $\begin{array}{c}\mathrm{T} \\
\left({ }^{\circ} \mathrm{C}\right)\end{array}$ & $\begin{array}{c}\mathrm{P}_{\mathrm{atm}} \\
(\mathrm{hPa})\end{array}$ & $\begin{array}{c}\text { Accum. } \\
\text { prec. } \\
24 \mathrm{hrs} \\
(\mathrm{mm})\end{array}$ & $\begin{array}{c}\text { Accum. } \\
\text { prec. } \\
48 \mathrm{hrs} \\
(\mathrm{mm})\end{array}$ & $\begin{array}{c}\text { Accum. } \\
\text { prec. } \\
7 \text { days } \\
(\mathrm{mm})\end{array}$ & $\begin{array}{c}\text { Mean wind } \\
(\mathrm{m} / \mathrm{s})\end{array}$ & $\begin{array}{c}\text { Humidity } \\
\mathrm{w}(\%)\end{array}$ \\
\hline 22.08 .2013 & 12.6 & 1007.5 & 1.3 & 6.9 & 14.1 & 7 & 75 \\
\hline 28.02 .2013 & 2.1 & 1030.5 & 0.7 & 8.3 & 60.4 & 5 & 96 \\
\hline 21.01 .2013 & 3.6 & 1006.5 & 0.0 & 0.0 & 14.9 & 6 & 66 \\
\hline 12.12 .2012 & 0.1 & 1015.8 & 0.0 & 0.0 & 4.5 & 5 & 79 \\
\hline 18.11 .2012 & 1.9 & 1001.0 & 0.0 & 0.0 & 15.6 & 8 & 79 \\
\hline 17.10 .2012 & 3.3 & 1018.0 & 0.0 & 0.0 & 16.9 & 9 & 70 \\
\hline 02.09 .2012 & 13.2 & 1004.0 & 1.7 & 13.7 & 17.7 & 2 & 52 \\
\hline 16.08 .2012 & 15.1 & 1014.0 & 0.0 & 0.0 & 89.2 & 9 & 74 \\
\hline
\end{tabular}


The accumulated precipitation can give a reasonable clue as to the extent of saturation of the top cover soil. Given the cover's presumed porosity and drainage capacity, 24-hr and $48 \mathrm{hr}$ precipitation are of special interest. During the study period, three wet events $(48 \mathrm{hr}$ accumulation) are recorded, i.e. in September 2012 and in February and August 2013, while December 2012 was particularly dry (7-day accumulation). Atmospheric pressure during the time of sampling was in the typical range of 1001 to $1031 \mathrm{hPa}$. The pressure evolution in the hours preceding sampling, which may be of greater interest due to its effect on gas flow, is examined in Chapter 4.4.2.

\subsection{Field Measurements and Analyses}

\subsubsection{Sampling Program}

Monthly measurements were performed in order to obtain gas concentrations for different weather conditions in Iceland, i.e. colder and warmer weathers. Sampling took place on 8 occasions between August 2012 and August 2013, i.e. during seven consecutive months August 2012 - February 2013, and in August 2013, see Table 2. In March - July 2013 the author of this study was on leave. Sampling dates covered the temperature range typically encountered in Iceland over the year, although fewer samples were obtained during summer.

Table 2 A summary of sampling dates and field measurements performed during the study period August 2012 - August 2013 at the Fiflholt landfill.

\begin{tabular}{|c|c|c|c|c|c|c|c|}
\hline Sampling date & $\begin{array}{c}\text { Gas } \\
\text { profile } \\
\text { C2-N }\end{array}$ & $\begin{array}{c}\text { Gas } \\
\text { profile } \\
\text { C2-S }\end{array}$ & $\begin{array}{l}\text { Gas } \\
\text { flux }\end{array}$ & $\begin{array}{l}\text { Profile } \\
\text { temp. }\end{array}$ & $\begin{array}{l}\text { Mon. } \\
\text { well } \\
\text { conc. }\end{array}$ & $\begin{array}{l}\text { Soil } \\
\text { sample }\end{array}$ & Remarks \\
\hline $\begin{array}{l}\text { August 16, } \\
2012\end{array}$ & $X$ & & & & & & $\begin{array}{l}\text { Difficulty } \\
\text { installing } \\
\text { tubes at } \mathrm{C} 2-\mathrm{S}\end{array}$ \\
\hline $\begin{array}{l}\text { September 2, } \\
2012\end{array}$ & $\mathrm{X}$ & & & & $X(C 2-S)$ & & $\begin{array}{l}\text { Installation of } \\
\text { tubes at C2-S } \\
\text { complete. }\end{array}$ \\
\hline $\begin{array}{l}\text { October 17, } \\
2012\end{array}$ & $\mathrm{X}$ & $\mathrm{X}$ & $\mathrm{X}$ & & $\mathrm{X}$ & & \\
\hline $\begin{array}{l}\text { November } 18 \text {, } \\
2012\end{array}$ & $X$ & $\mathrm{X}$ & $\mathrm{X}$ & $\mathrm{X}$ & & & \\
\hline $\begin{array}{l}\text { December 12, } \\
2012\end{array}$ & $X$ & X & $X$ & $\mathrm{X}$ & & $\mathrm{X}$ & \\
\hline $\begin{array}{l}\text { January } 21, \\
2013\end{array}$ & $\mathrm{X}$ & $\mathrm{X}$ & $\mathrm{X}$ & $\mathrm{X}$ & $\mathrm{X}$ & & \\
\hline $\begin{array}{l}\text { February 28, } \\
2013\end{array}$ & $X$ & $\mathrm{X}$ & $X$ & $\mathrm{X}$ & $\mathrm{X}$ & & \\
\hline $\begin{array}{l}\text { August 22, } \\
2013\end{array}$ & $X$ & $\mathrm{X}$ & & $\mathrm{X}$ & $X$ & & \\
\hline
\end{tabular}

Sampling took place at two different locations on cell 2 of the Fíflholt landfill, in proximity to the existing gas monitoring wells. The two locations were identified as $\mathrm{C} 2-\mathrm{N}$ and $\mathrm{C} 2-\mathrm{S}$, see Figure 6. Samples were taken from $\mathrm{C} 2-\mathrm{N}$ since the beginning of the study period and from C2-S since October, 2012. A total of 106 measurements were obtained throughout the study period ( 8 dates $\mathrm{x} 8$ tubes at $\mathrm{C} 2-\mathrm{N}$ and 6 dates $\mathrm{x} 7$ tubes at $\mathrm{C} 2-\mathrm{S}$ ). 
Profile temperatures were measured starting November 2012 and gas concentrations in monitoring wells were measured on five occasions during the study period. Gas flux measurements were performed by Guðrún Meyvantsdóttir between October 2012 and February 2013, as part of a parallel study on gas emissions from Fíflholt (Meyvantsdóttir, 2013, unpublished data). Table 3 provides an overview of the equipment used for this study and its origin.

Table 3 Overview of measurements performed for this study and origin of equipment used.

\begin{tabular}{|l|l|l|}
\hline Measurements & Tools and equipment & Owner \\
\hline Soil analysis & Filters, ovens, etc. & Innovation Center Iceland \\
\hline $\begin{array}{l}\text { Gas concentration } \\
\text { (gas profile) } \mathrm{CH}_{4}, \\
\mathrm{CO}_{2}, \mathrm{O}_{2}\left(\mathrm{H}_{2} \mathrm{~S}\right)\end{array}$ & $\begin{array}{l}\text { Travel gas analyzer (Geotechnical } \\
\text { Instruments GA2000 Plus) }\end{array}$ & EFLA Consulting Engineers \\
\hline Gas flux & $\begin{array}{l}\text { Gas flux meter (West Systems portable } \\
\text { soil flux meter for Carbon Dioxide and } \\
\text { Methane (dynamic chamber method)) }\end{array}$ & $\begin{array}{l}\text { Iceland GeoSurvey (ÍSOR } \\
\text { (ÍSOR) }\end{array}$ \\
\hline Other measurements & $\begin{array}{l}\text { Thermometer (FLUKE 54-II) } \\
\text { Climatological conditions (temperature, } \\
\text { precipitation, wind, moisture, pressure) }\end{array}$ & $\begin{array}{l}\text { EFLA Consulting Engineers } \\
\text { The Icelandic Meteorological } \\
\text { Office }\end{array}$ \\
\hline
\end{tabular}

\subsubsection{Experimental Setup}

The tubes were successfully installed on August 9 and August 16, 2012 (C2-N) and September 2, 2012 (C2-S). Both locations were in proximity to existing monitoring wells, previously installed to monitor the landfill gas composition. This way, as a complement to gas profile measurements in the soil cover, it was possible to assess with sufficient accuracy the landfill gas composition within the waste layer, right below the sampling tubes. Measuring at two locations on top of the same cell would also to some extent take into account spatial variability of gas emissions, since it is known that gas emissions can vary considerably from one location to the next within the same cell (Röwer et al., 2010).

A total of 7 tubes were installed at C2-S and 8 tubes at C2-N, depths 5, 10, 20, 30, 40, 60 (only C2-N), 80 and $120 \mathrm{~cm}$, see Table 3 . A $60 \mathrm{~cm}$ tube was not installed at C2-S because it was damaged during installation. The tubes were installed in a hectagon or heptacon shape approx. $30-35 \mathrm{~cm}$ apart, forming a circle with a diameter of approx. $70 \mathrm{~cm}$ (see photos in Figure 8, Figure 9 and layout in Figure 10). This was to avoid interference between sampling tubes during sampling. A summary of sampling tubes and lengths at each location can be seen in Table 4. The longest tube, $120 \mathrm{~cm}$, was placed in the middle of the circle. 


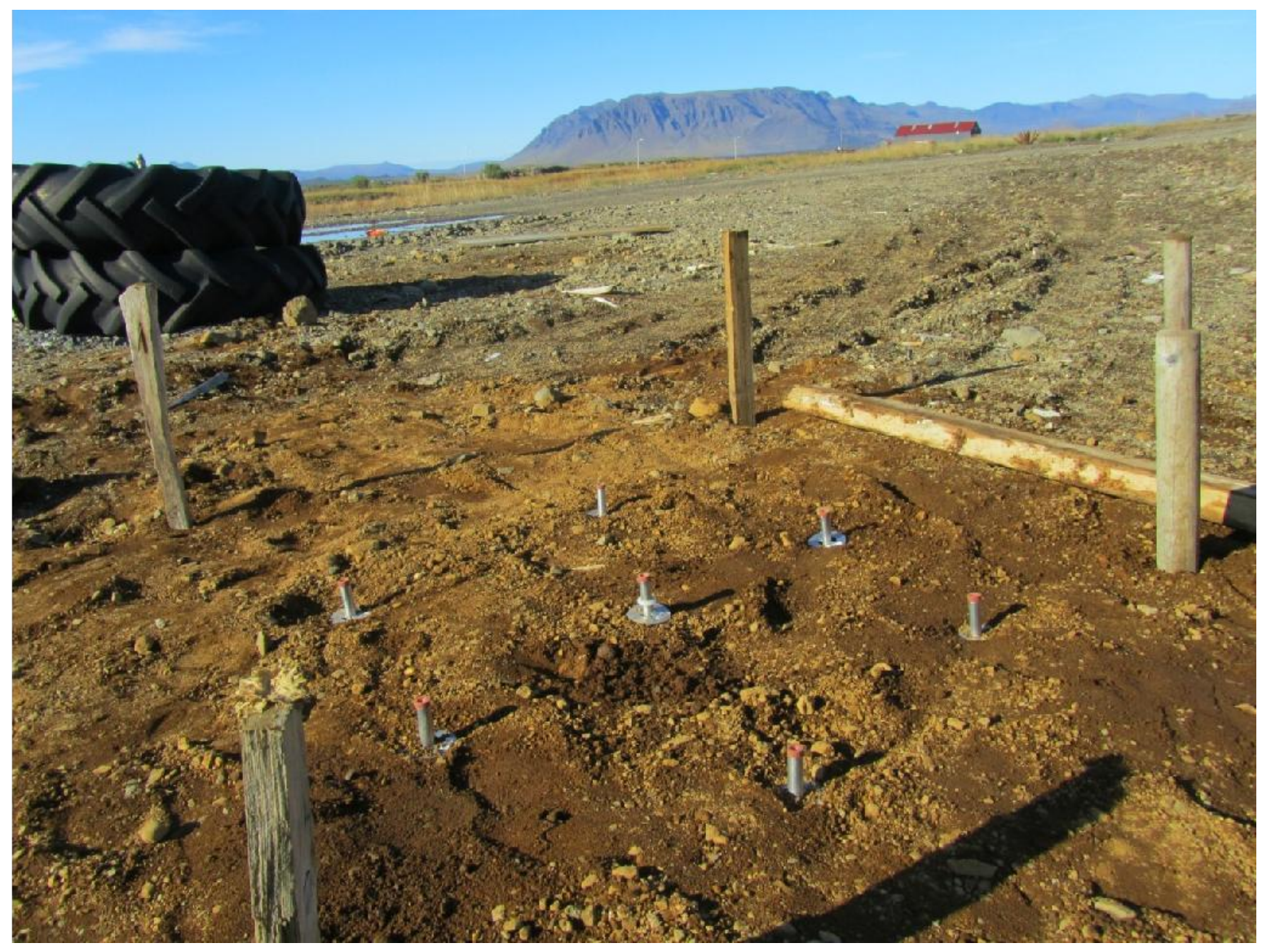

Figure $8 \mathrm{~A}$ view to the north over sampling tubes on cell 2 at Fiflholt landfill, south end (C2-S). Monitoring well to the left, protected by tires, Photo: AK, September 2012.

An ongoing German research project of methane oxidation in landfills (MiMethox) has used sampling tubes of depths 5, 10, 20, 40,60, 90 and $120 \mathrm{~cm}$ (Rachor and Gebert, 2009), while a Canadian study has measured from depths 5, 10, 20, 30, 40, 60 and $80 \mathrm{~cm}$ (Roncato and Cabral, 2012). These studies showed oxidation zones at around 40 to $60 \mathrm{~cm}$ depths (Rachor and Gebert, 2009) and 40 to $70 \mathrm{~cm}$ depths depending on gas influx rates (Roncato and Cabral, 2012). Given the coarse nature of the soil cover observed at the Fíflholt landfill, and that no studies of this nature have been performed in Iceland, the above-mentioned depths were chosen, i.e. $5,10,20,30,40,60,80$ and $120 \mathrm{~cm}$. That way a more accurate gas profile could be obtained, with tubes accessing the anaerobic zone at the bottom of the soil cover with high influence from the landfill gas, and the aerated zone where oxidation can take place. 


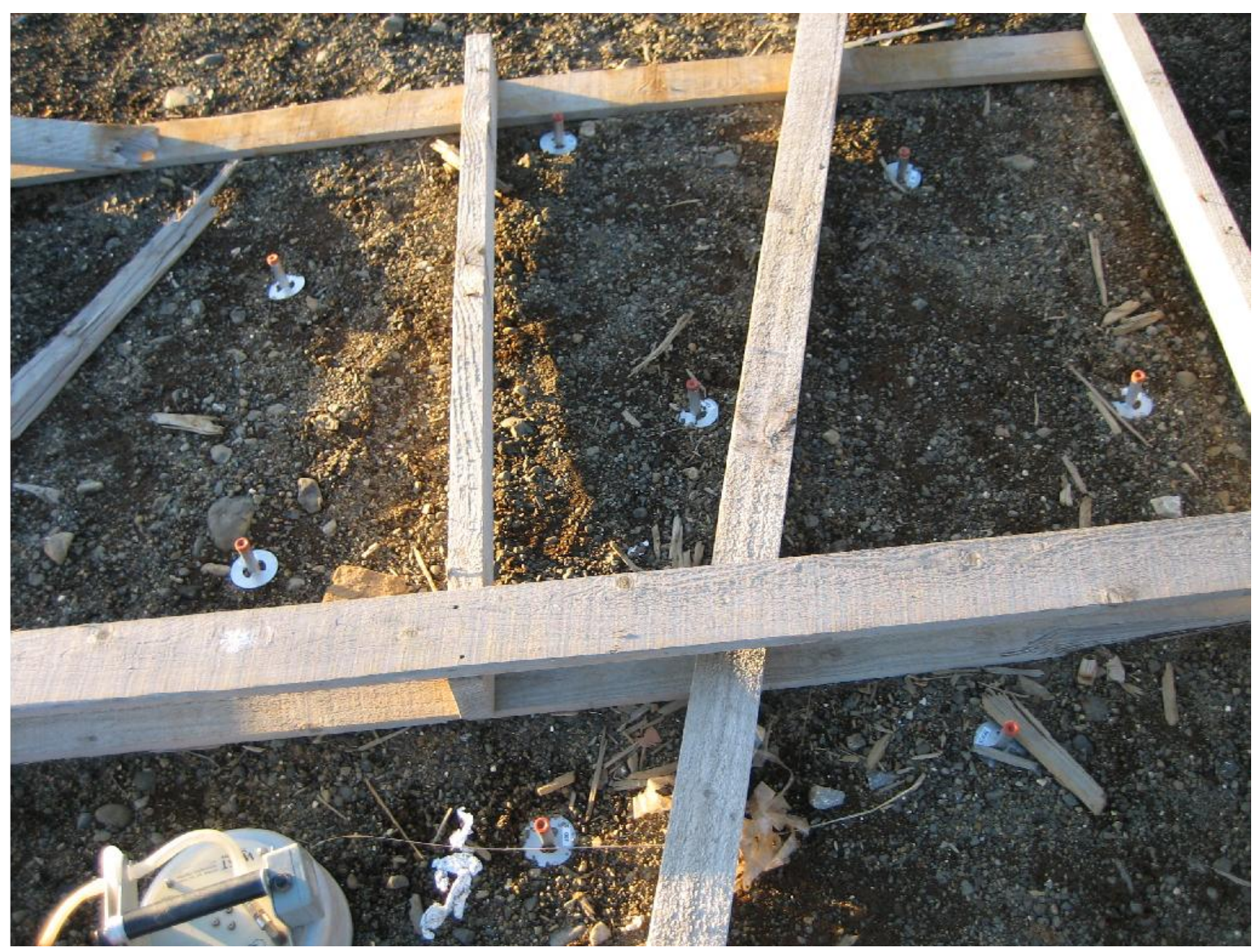

Figure 9 Sampling tubes at C2-N at Fiflholt landfill, north end. Tubes are protected by wooden pallet. Photo: AK, October 2012.

The tubes were made from stainless steel, 15 x $1 \mathrm{~mm}$ (13 mm inner diameter), see Figure 11. Aluminum tubes have been used in other studies (Rachor and Gebert, 2009, and Roncato and Cabral, 2012), but this material was deemed unfit for this study, given the coarse nature of the cover soil at Fiflholt and rough weather conditions in Iceland, notably the effects of frost heave. An Austrian study used stainless steel gas probes that were closed at the bottom and perforated over the lower $4 \mathrm{~cm}$ (Huber-Humer et al, 2009). In this study, simple tubes were used, open at the bottom. 


\section{CELL 2}

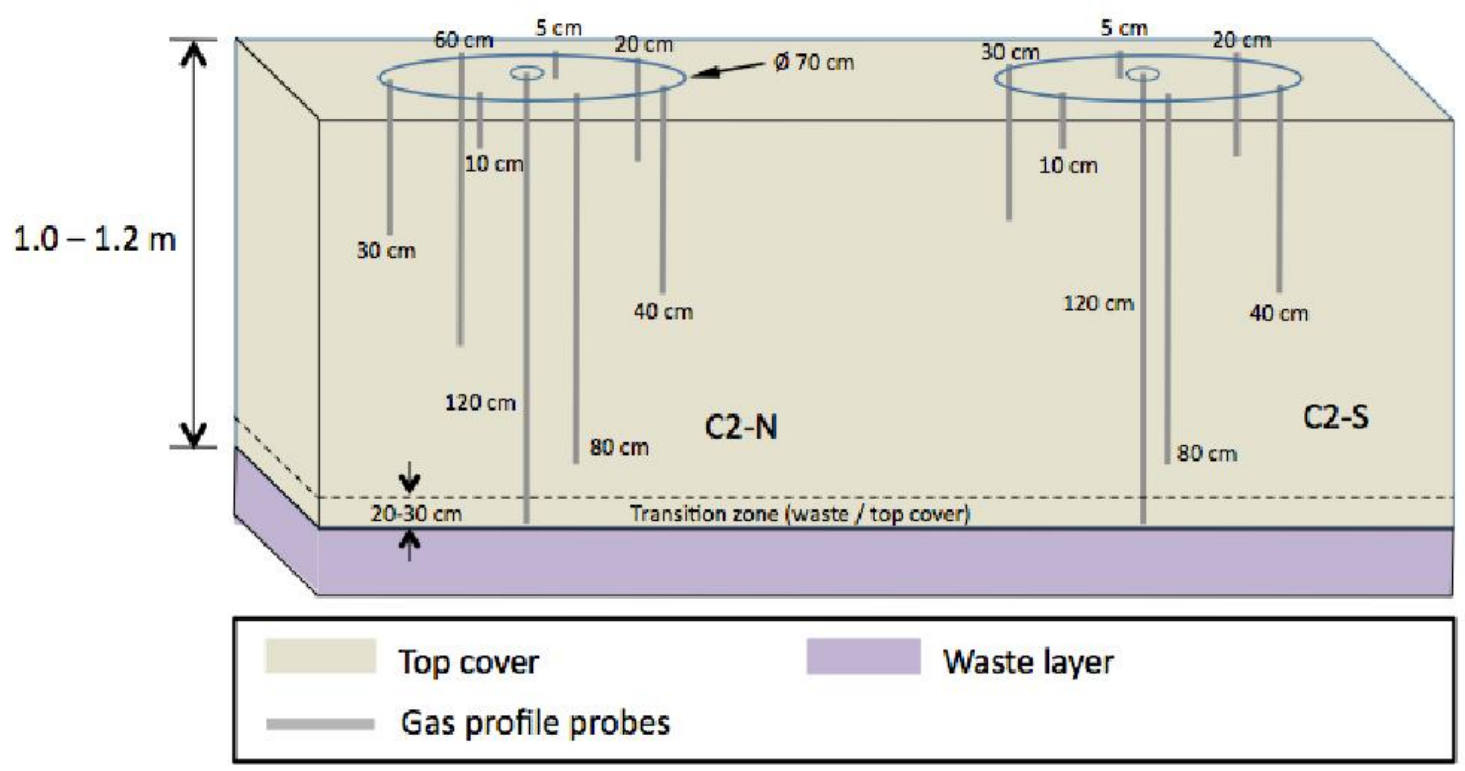

Figure 10 Profile view of gas measurement setup in Cell 2 at Fiflholt landfill.

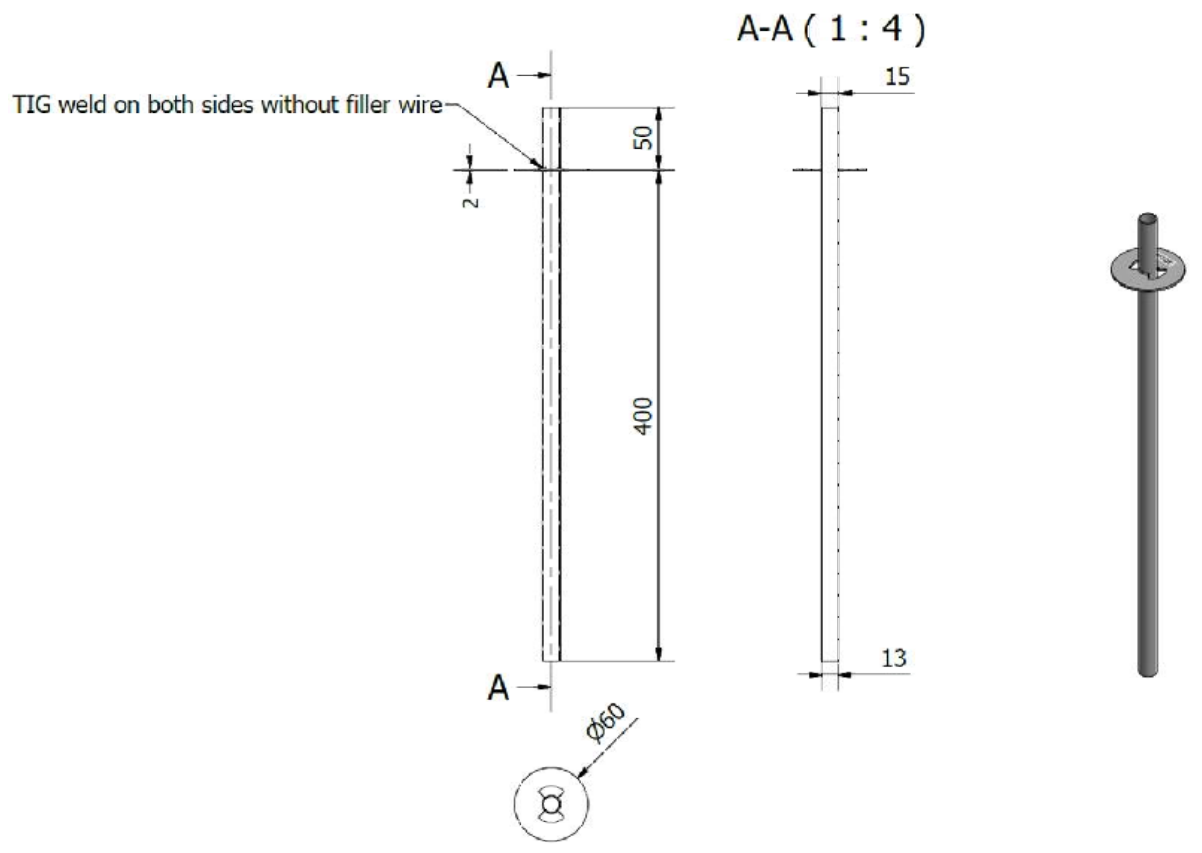

Figure 11 Drawing of $40 \mathrm{~cm}$ sampling tube used for gas profile measurements, profile and $3 D$ image. All numbers are in $\mathrm{mm}$.

The tubes were $5 \mathrm{~cm}$ longer than their assigned depths, i.e. with $5 \mathrm{~cm}$ protruding from the soil surface. To ensure vertical stability, the tubes were built with discs in line with the soil surface, on top of which stickers were attached to identify depths. The design of the tubes made it easy to see if the tubes had elevated slightly towards the surface, in which case they were repositioned, see Chapter 3.3.3. 
Installation of the sampling tubes was carried out over the course of three visits to the landfill. At one point during the process, sampling tubes had to be extracted from the soil cover and relocated because of boulders in the cover layer that made installation of some of the deeper tubes impossible. Given the very coarse nature of the cover soil, a sharp steel lance was inserted through the tubes to facilitate installation. Both tube and lance were driven down into the soil with a sledgehammer, that way avoiding damage to and the filling of the tube. After installation, the tubes were sealed with rubber stops (Terumo). Measurement techniques are described in the following chapter.

Table 4 Summary of sampling tubes and tube lengths at locations $C 2-N$ and $C 2-S$ on Cell 2 at the Fiflholt landfill.

\begin{tabular}{|l|l|}
\hline $\mathrm{C} 2-\mathrm{N}$ & $\mathrm{C} 2-\mathrm{S}$ \\
\hline $5 \mathrm{~cm}$ & $5 \mathrm{~cm}$ \\
\hline $10 \mathrm{~cm}$ & $10 \mathrm{~cm}$ \\
\hline $20 \mathrm{~cm}$ & $20 \mathrm{~cm}$ \\
\hline $30 \mathrm{~cm}$ & $30 \mathrm{~cm}$ \\
\hline $40 \mathrm{~cm}$ & $40 \mathrm{~cm}$ \\
\hline $60 \mathrm{~cm}$ & - \\
\hline $80 \mathrm{~cm}$ & $80 \mathrm{~cm}$ \\
\hline $120 \mathrm{~cm}$ & $120 \mathrm{~cm}$ \\
\hline
\end{tabular}

\subsubsection{Gas Profile Measurements}

Concentrations of $\mathrm{CH}_{4}, \mathrm{CO}_{2}, \mathrm{O}_{2}$ and $\mathrm{N}_{2}$ were measured at different depths at the two locations, C2-N and C2-S, during each sampling date, see Table 2. Gas concentrations were also measured at monitoring wells on five occasions, see Chapter 3.3.4. Sampling methods were based on recent gas profile measurements (Gebert et al., 2011, Röwer, I.U., et al., 2011).

Upon arrival at Fíflholt on each sampling date, sampling tubes were purged of their volume using a $60 \mathrm{ml}$ syringe and needle. This was done in order to empty sampling tubes of their content accumulated during the past days and weeks, and allow current gas to seep from the soil into the tubes at respective depths. Volumes within tubes were calculated beforehand to determine how many times syringes full of air were to be extracted.

When temperatures started to drop in October, it was observed throughout the rest of the study that the three shallowest tubes $(5,10$ and $20 \mathrm{~cm})$ were slightly loose in the ground. On occasion after colder periods in winter it was also observed upon arrival to the site that some of the shallowest tubes had risen upwards to the surface by a few $\mathrm{cm}$ due to forces of frost heave, see Figure 12. When this occurred the tubes were repositioned into the ground and then purged. The ground surrounding the tubes was not sealed, e.g. with bentonite, as this was neither considered necessary for the deeper tubes nor effective for the shallowest tubes. 


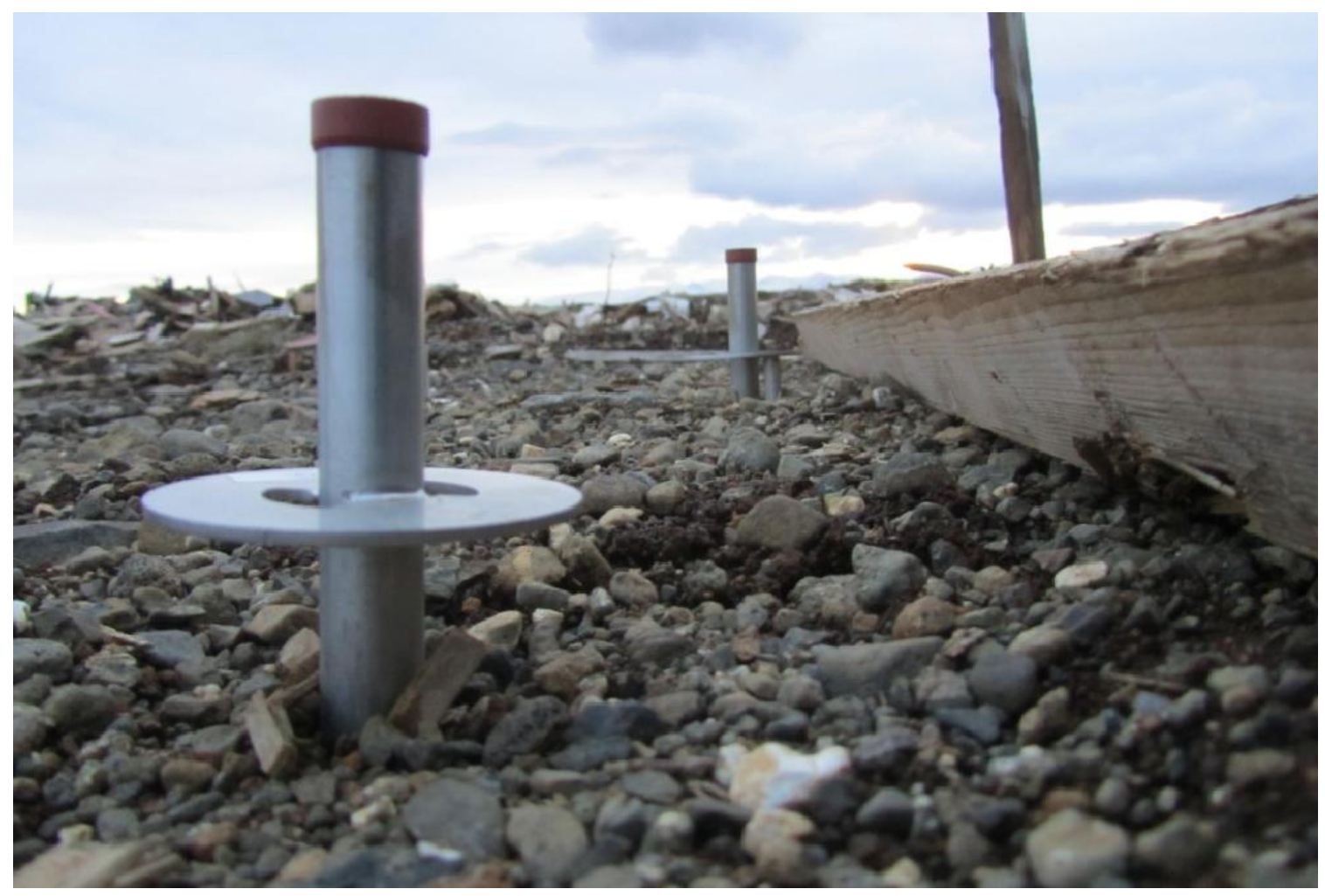

Figure 12 Shallow sampling tubes $(20 \mathrm{~cm}$ in the front and $5 \mathrm{~cm}$ at the back) being pushed up through the surface by forces of frost heave. Photo: $A K$.

After purging the tubes, between 30 minutes and 1 hour passed before measurements began. Gas samples were extracted from the sampling tubes using the $60 \mathrm{ml}$ syringe and needle, and fed into a gas analyzer (Geotechnical Instruments GA 2000 Plus), see Figure 13. This was performed $4-8$ times per tube, or until the analyzer showed consistency in measurements. In the beginning of the study period or in August 2012, however, gas samples were only extracted once from each sampling tube. When analyzing the data and calculating results, which are presented in Chapter 4.1, anomalies in gas concentration measurements were discarded and mean values calculated.

Table 5 Accuracy of gas concentration measurements of GA 2000 Plus Gas Analyser (Geotechnical Instruments, 2006).

\begin{tabular}{|l|l|l|l|}
\hline Gas & $0-5 \%$ vol & $5-15 \%$ vol & $15 \%$-FS \\
\hline $\mathrm{CH}_{4}$ & $\pm 0.5 \%$ & $\pm 1.0 \%$ & $\pm 3.0 \%$ \\
\hline $\mathrm{CO}_{2}$ & $\pm 0.5 \%$ & $\pm 1.0 \%$ & $\pm 3.0 \%$ \\
\hline $\mathrm{O}_{2}$ & $\pm 1.0 \%$ & $\pm 1.0 \%$ & $\pm 1.0 \%$ \\
\hline Balance $\left(\mathrm{N}_{2}\right)$ & $\pm 1.0 \%$ & $\pm 1.0 \%$ & $\pm 3.0 \%$ \\
\hline
\end{tabular}

The gas analyzer measures $\mathrm{CO}_{2}$ and $\mathrm{CH}_{4}$ by dual wavelength infrared cell with reference channel and $\mathrm{O}_{2}$ by internal electrochemical cell. The analyzer can pump the gas with a typical flow of $300 \mathrm{~cm}^{3} / \mathrm{min}(300 \mathrm{ml} / \mathrm{min})$ or $5 \mathrm{ml} / \mathrm{s}$. Accuracies for the three measured gases are shown in Table 5 (Geotechnical Instruments, 2006). The analyzer calculates the remaining balance in the measured air, i.e. the difference between the sum of the other gases to $100 \%$, 
which is assumed to be $\mathrm{N}_{2}$. Other landfill trace gases such as sulfides, disulfides, ammonia, hydrogen and carbon monoxide, as well as atmospheric trace gases like Argon were outside the scope of this study and therefore not measured.

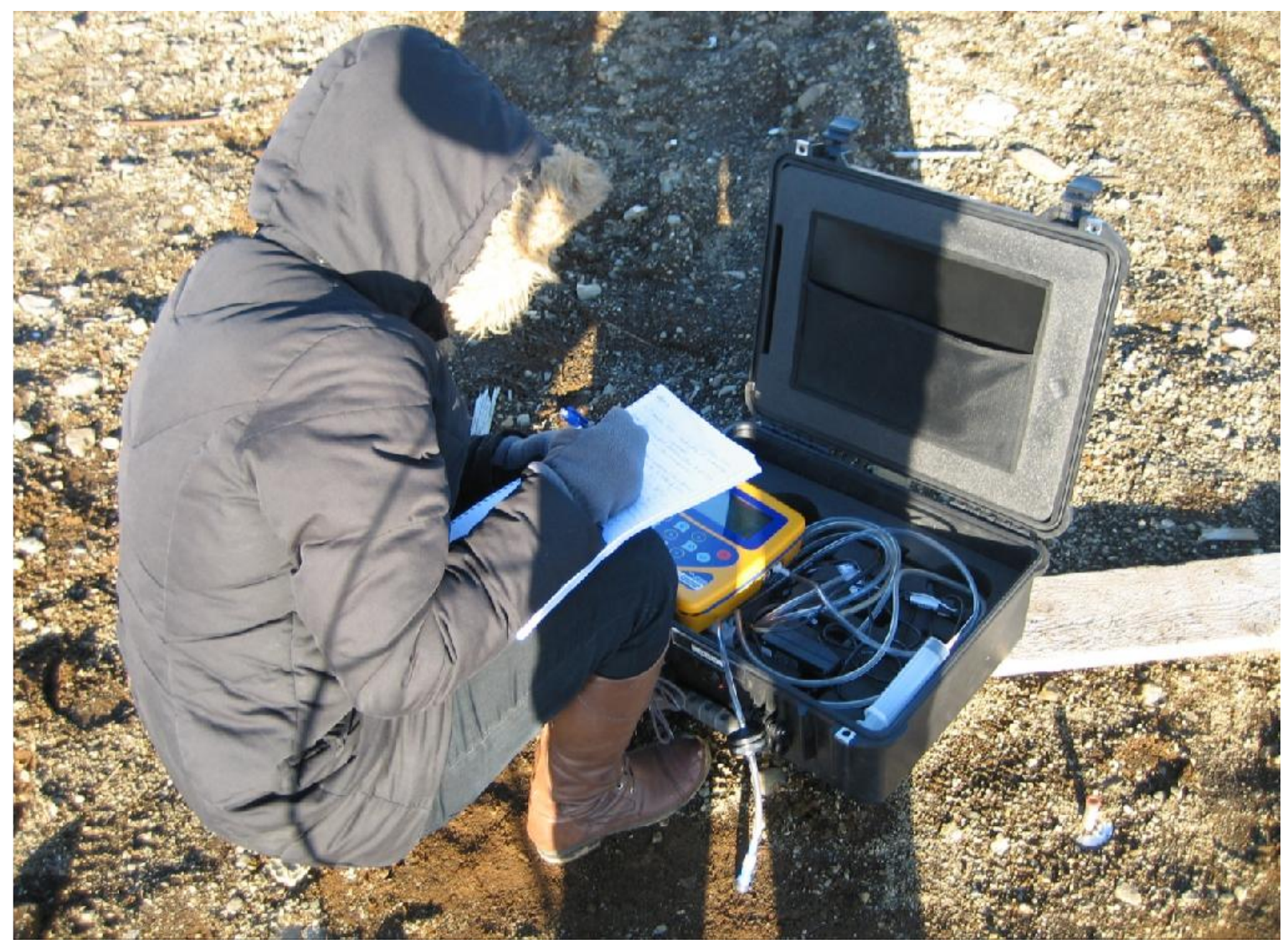

Figure 13 Gas profile measurements at Fiflholt landfill using the Geotechnical Instruments GA2000 Plus. Photo: GM, Oct 2012.

\subsubsection{Landfill Gas Concentration}

The two study locations $\mathrm{C} 2-\mathrm{N}$ and $\mathrm{C} 2-\mathrm{S}$ were chosen close to the two functioning wells at cell 2 that serve to monitor landfill gas concentration at Fíflholt, see Figure 6. The wells were drilled in 2009 down to 8 - 9 m depth (Ræktunarsamband Flóa og Skeiða, 2009), the cell being about $6-7 \mathrm{~m}$ deep (SWMWIRO, 2011), and fitted with slotted casings, unslotted at the top $2,5 \mathrm{~m}$. Borehole walls within the well were sealed with bentonite and at the top the casing was covered with a plastic pipe and locking cap.

Table 6 Summary of recent gas concentration measurements from monitoring wells $C 2-S$ and $C 2-N$ at Cell 2 at the Fiflholt landfill (Atli Geir Júliusson, 2011; Mannvit, 2012).

\begin{tabular}{|l|l|l|l|l|l|l|l|}
\hline Well & Date & Done by & $\mathrm{CH}_{4}[\%]$ & $\mathrm{CO}_{2}[\%]$ & $\mathrm{O}_{2}[\%]$ & $\mathrm{N}_{2}[\%]$ & Remark \\
\hline \multirow{3}{*}{ C2-S } & May 5. 2010 & AGJ & 59 & 41 & 0 & 0 & no pumping \\
\cline { 2 - 8 } & \multirow{2}{*}{ Oct. 2011 } & \multirow{2}{*}{ Mannvit } & 54 & 44.1 & 0 & 1.9 & no pumping \\
\cline { 5 - 9 } & & 53.3 & 44.5 & 0 & 2.2 & $7 \mathrm{Nm}^{3} / \mathrm{h}$ for $24 \mathrm{hrs}$ \\
\hline \multirow{3}{*}{ C2-N } & May 5. 2010 & AGJ & 61 & 39 & 0 & 0 & no pumping \\
\cline { 2 - 8 } & \multirow{2}{*}{ Oct. 2011 } & \multirow{2}{*}{ Mannvit } & 37.2 & 36.3 & 0.6 & 25.9 & no pumping \\
\cline { 4 - 8 } & & 48.3 & 38 & 2.2 & 11.5 & $5 \mathrm{Nm}^{3} / \mathrm{h}$ for $24 \mathrm{hrs}$ \\
\hline
\end{tabular}


Landfill gas concentrations have been monitored annually in these wells since instalment. Recent measurements show methane concentrations of $53-59 \%$ at $\mathrm{C} 2-\mathrm{S}$ and $37-61 \%$ at $\mathrm{C} 2-$ N, see Table 6. Aside from values obtained in October 2011, these are typical values for landfill gas in active phase. Lower $\mathrm{CH}_{4}$ values measured at $\mathrm{C} 2-\mathrm{N}$ along with high values of $\mathrm{O}_{2}$ and $\mathrm{N}_{2}$ in October 2011 indicate the intrusion of atmospheric air either into the well or waste layer.

For this study, landfill gas concentrations within the waste layer were measured on 5 occasions in the same wells during the study period; see Table 2 and results in Chapter 0. Wells were not measured in November and December 2012 due to technical issues. Measurements were performed using the gas analyzer detailed in Chapter 3.3.3 (Geotechnical Instruments GA 2000 Plus), and took place immediately after opening the wells, i.e. they were not vented beforehand. Gas concentrations were logged upon stabilization, typically after pumping for 0-5 minutes.

\subsubsection{Soil Temperature Measurements}

Soil temperature measurements were added to the study in November to corroborate with the oxidation efficiency calculations at different depths. Temperature has been found to have a profound effect on the $\mathrm{CH}_{4}$ oxidation activity where gas transport is governed by diffusion and $\mathrm{CH}_{4}$ emissions have been negatively correlated with soil temperature (Scheutz et al., 2009).

The soil temperature was measured upon the completion of gas profile measurements, using a Fluke 54-II thermometer and a wire. The wire was connected to the thermometer, the rubber stopper removed from the tubes, and the wire led down to the bottom of each sampling tube. Temperatures were read off the thermometer upon stabilization.

\subsubsection{Gas Flux Measurements}

Gas flux measurements were performed in parallel with this study, as a part of a thesis by Guðrún Meyvantsdóttir on methane emissions from Icelandic landfills (Meyvantsdóttir, G., 2013, unpublished data). On five occasions, the gas flux was measured at cell 2 in proximity to the installed sampling tubes, i.e. within $10 \mathrm{~m}$ of both locations.

Gas flux from the surface was measured using a West Systems portable soil flux meter for Carbon dioxide and Methane, using the dynamic chamber method. The accumulation chamber used has a diameter of $200 \mathrm{~mm}$ and height $97 \mathrm{~mm}$, net volume $3.01440 * 10^{-3} \mathrm{~m}^{3}$. The flux meter is equipped with a portable carbon dioxide detector, a double beam infrared sensor compensated for temperature and pressure variation. The accuracy depends on the measured flux (West Systems, 2007):

$$
\begin{array}{ll}
0 \text { to } 0.5 \text { moles } \mathrm{m}^{2} / \text { day } & 25 \% \text { accuracy } \\
0.5 \text { to } 1 \text { moles } \mathrm{m}^{2} / \text { day } & 15 \% \text { accuracy } \\
1 \text { to } 150 \text { moles } \mathrm{m}^{2} / \text { day } & 10 \% \text { accuracy }
\end{array}
$$

The methane sensor is an IR spectrometer with the measurement range from 0.2 up to 300 moles $\mathrm{m}^{-2}$ day $^{-1}$. Like the $\mathrm{CO}_{2}$ detector, the accuracy depends on the measured flux (West Systems, 2007): 


$$
\begin{array}{ll}
0.2 \text { to } 10 \text { moles } \mathrm{m}^{-2} \text { day }^{-1} & 25 \% \text { accuracy } \\
10 \text { to } 150 \text { moles } \mathrm{m}^{-2} \text { day }^{-1} & 15 \% \text { accuracy }
\end{array}
$$

For each measurement, the chamber was placed on the ground and the flux was recorded for approx. 5 minutes. The reliability of each reading was assessed throughout the recording, typically showing good consistency. When sharp wind gusts occurred, a sharp rise or disturbance could sometimes be seen in measurements, indicating external influence in the gas chamber. This however only happened rarely and these measurements were discarded. External influence from atmospheric air is therefore not considered a major error factor.

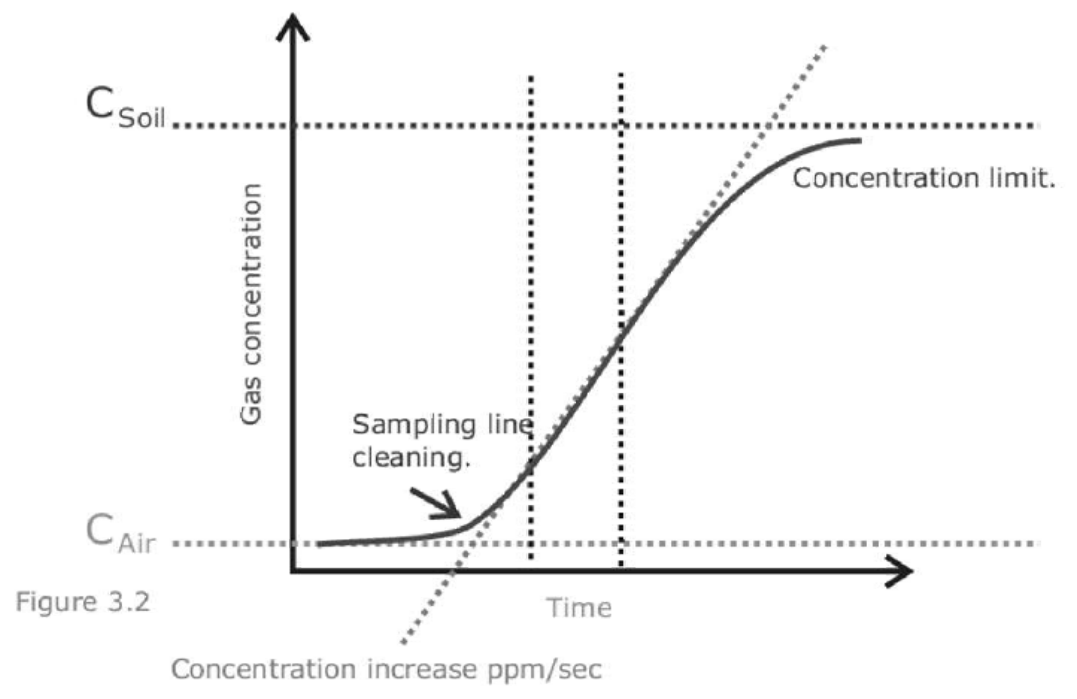

Figure 14 Flux curve on handheld display unit. $C_{\text {Soil }}$ is the target gas concentration in the soil, $C_{\text {Air }}$ is the target gas air concentration, 350 ppm in the case of carbon dioxide (West Systems, 2007). Figure from West Systems Handbook, 2007.

A handheld device displayed continuous gas concentration values in the chamber, see Figure 14. In the first part of the flux curve, the gas pumped from the accumulation chamber is replacing the gas into the pump, the tubes and the cell detector cell. When the target gas concentration becomes close to the soil concentration $\mathrm{C}_{\text {Soil }}$, the flux curve slope decreases, usually after a very long recording period. The flux is calculated choosing a reliable slope $a$ $[\mathrm{ppm} / \mathrm{s}]$, delimited by two vertical lines, see Figure 14, usually at an interval of the flux curve between 3 and 5 minutes into the recording. The net flux (moles $/ \mathrm{m}^{2} /$ day) is then calculated via the ideal gas law $(P V=n R T)$ using the chamber volume and surface, ambient pressure and temperature, i.e.

$$
\text { net flux }=a \cdot \frac{86400 \mathrm{sec} / \text { day } \cdot P}{10^{6} \cdot R \cdot T_{k}} \cdot \frac{V}{A}
$$

where $P$ is the barometric pressure [mBar or $\mathrm{HPa}$ ], $R$ is the gas constant 0.08314519 bar $\mathrm{L}$ $\mathrm{K}^{-1} \mathrm{~mol}^{-1}, T_{k}$ is the air temperature $[\mathrm{K}], V$ is the chamber net volume $\left[\mathrm{m}^{3}\right]$, and $A$ is the chamber inlet area $\left[\mathrm{m}^{2}\right]$. The net flux [moles $/ \mathrm{m}^{2} /$ day] is easily transferred into $\mathrm{g} / \mathrm{m}^{2} /$ day by multiplying the result with the molar weight of the gas in question, i.e. $\mathrm{CO}_{2}[44 \mathrm{~g} / \mathrm{mole}]$ or $\mathrm{CH}_{4}[16 \mathrm{~g} / \mathrm{mole}]$. 


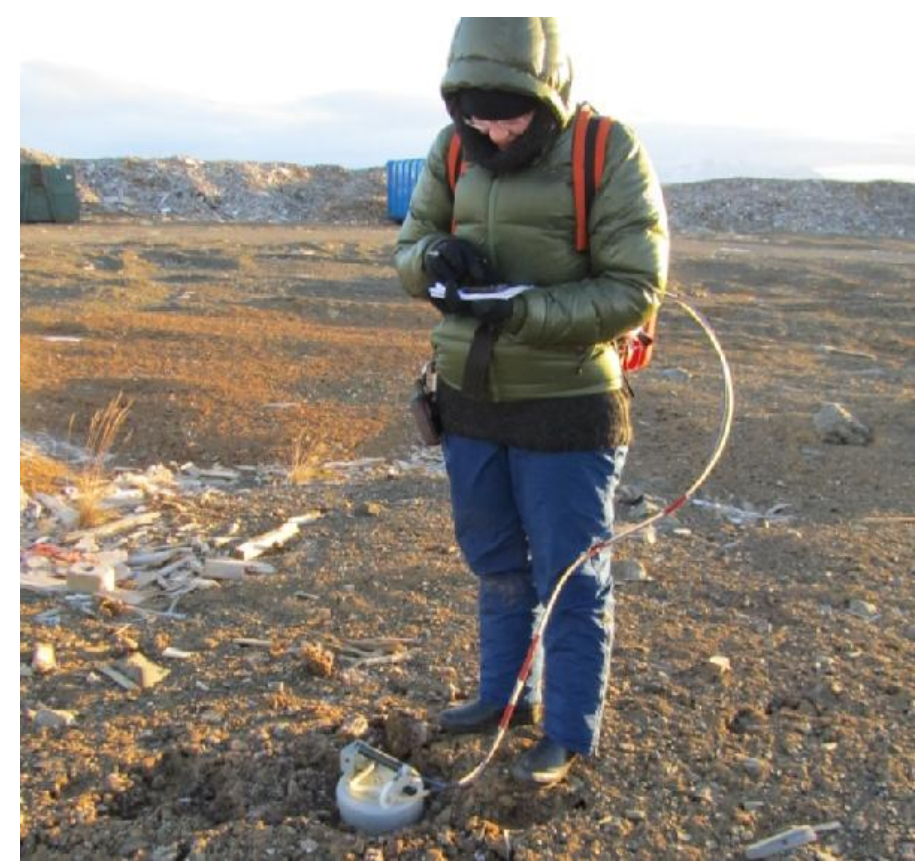

Figure 15 Gas flux measurements at the Fiflholt landfill, using the West Systems portable diffuse flux meter. Photo: AK, Nov 2012.

As discussed in Chapter 2.6.2, the chamber method is subject to many limitations. Given the very small area of the dynamic chamber used in this study, the high spatial variability of fluxes within the cell is not taken into account. Flux measurements were performed after a simple visual and olfactory inspection in order to identify high emission areas or hot spots, if any, but it is very likely that they were missed, see Chapter 5.2.

\subsubsection{Properties of the Top Cover and Soil Analysis}

The top cover soil, excavated from the landfill cells, is composed of volcanic and organic soil material, i.e. Histosol mixed with Histic Andosol and Brown Andosol, typical for the region (Arnalds, Ó. \& Óskarsson, H., 2009). Histic Andosol can, much like Histosol, retain large amounts of water and drains rather poorly. The cover is approx. $1-1,5 \mathrm{~m}$ thick, fulfilling the requirements of the landfill's operation permit. As mentioned in Chapter 3.2.1, the top cover, see Figure 16, consists of $15-20 \mathrm{~cm}$ chopped wood, a thin layer of gravel and approx. $1 \mathrm{~m}$ of excavated soil from the site. According to site technicians, the top cover should be near identical on top of the entire cell, i.e. same composition and thickness.

Field samples from the surface soil cover were taken on December 12, 2012, from the middle of the cell, not far from C2-N. An approx. $1 \mathrm{~m}$ x $1 \mathrm{~m}$ square was excavated with a digger and sampling performed using guidelines from the Icelandic Road Administration (The Icelandic Road and Coastal Administration, 2006). 


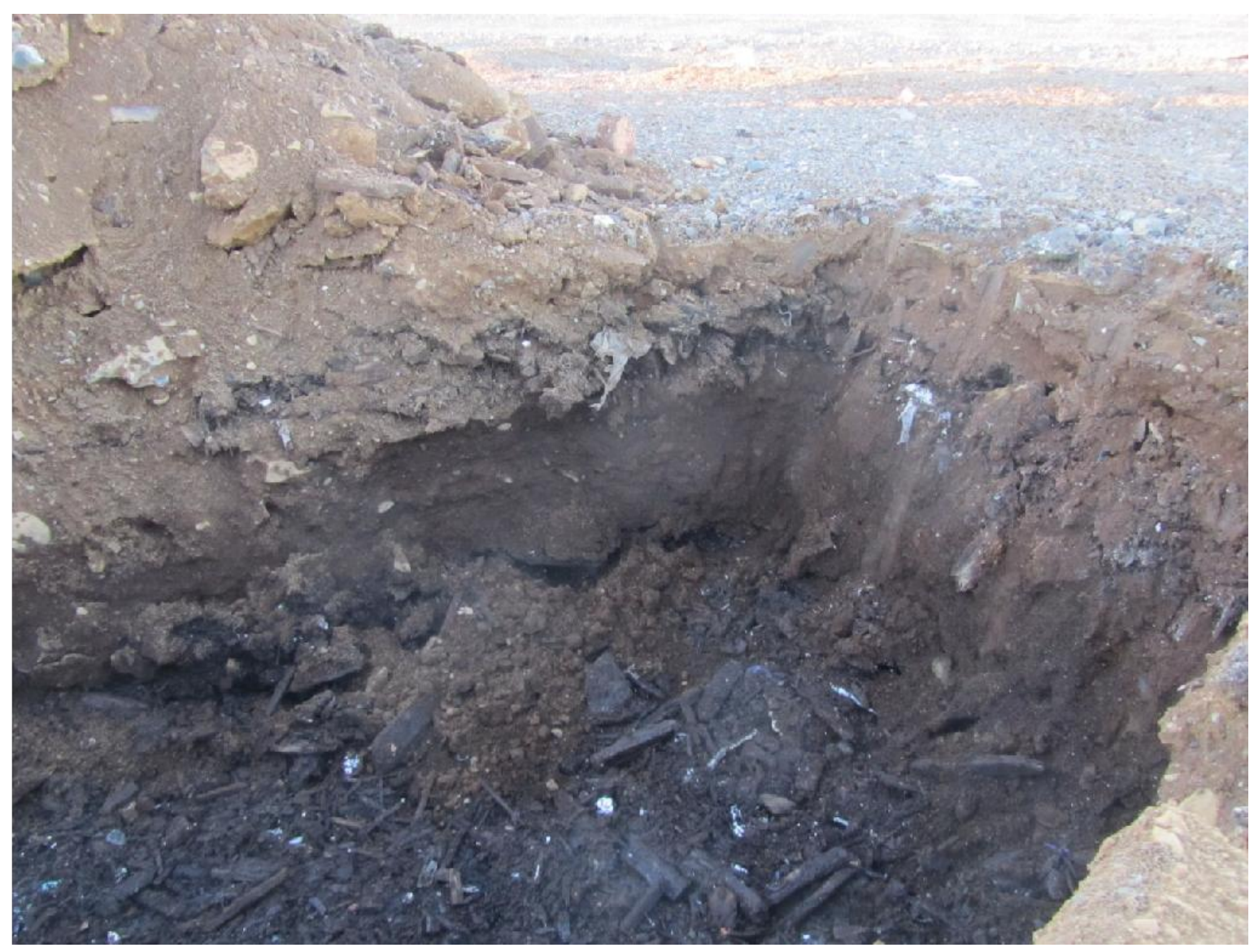

Figure 16 Excavated cover from Cell 2 at the Fiflholt landfill. A sample was extracted from the excavated mound for particle size distribution analysis. Decomposing chopped wood is visible at the bottom of the cover as well as scattered large boulders from the top cover. Photo: AK, Dec 2012.

The soil sample was analyzed in February 2013 at the Material Science \& Concrete Technology Department of the Innovation Center Iceland. Granulometric properties and carbon content were evaluated in the analysis to better understand the characteristics of the cover soil and to corroborate with results from gas profile measurements.

Icelandic standard ÍST EN 933-1 was used for the granulometric analysis. The analysis was performed via sieving techniques of a dry sample and grain sizes [0,063 mm - $63 \mathrm{~mm}]$. Results were used to generate a size distribution or granulometric curve for the cover soil and determine its classification, see Figure 17.

Main effective sizes were $\mathrm{D}_{10}=0.30 \mathrm{~mm}, \mathrm{D}_{30}=0.78 \mathrm{~mm}$ and $\mathrm{D}_{60}=2.80 \mathrm{~mm}$. The uniformity coefficient was $C_{u}=D_{60} / D_{10}=9.3$, which is a rather high value, signifying that the soil mass consists of different ranges of particle sizes, as can be seen on the granulometric curve. Its coefficient of gradation was $C_{c}=0.7$, which indicates that the soil is poorly graded. The soil cover is in other words a highly porous gravely sand, permitting the influx of atmospheric air and thus supporting methane oxidation. According to the ASTM D2487 standard the soil would be graded as SP-SM, i.e. a poorly graded sand with gravel and silt. The water content of the sample, representative only of the time of sampling on December 12, 2012, was $16.3 \%$ dw. 


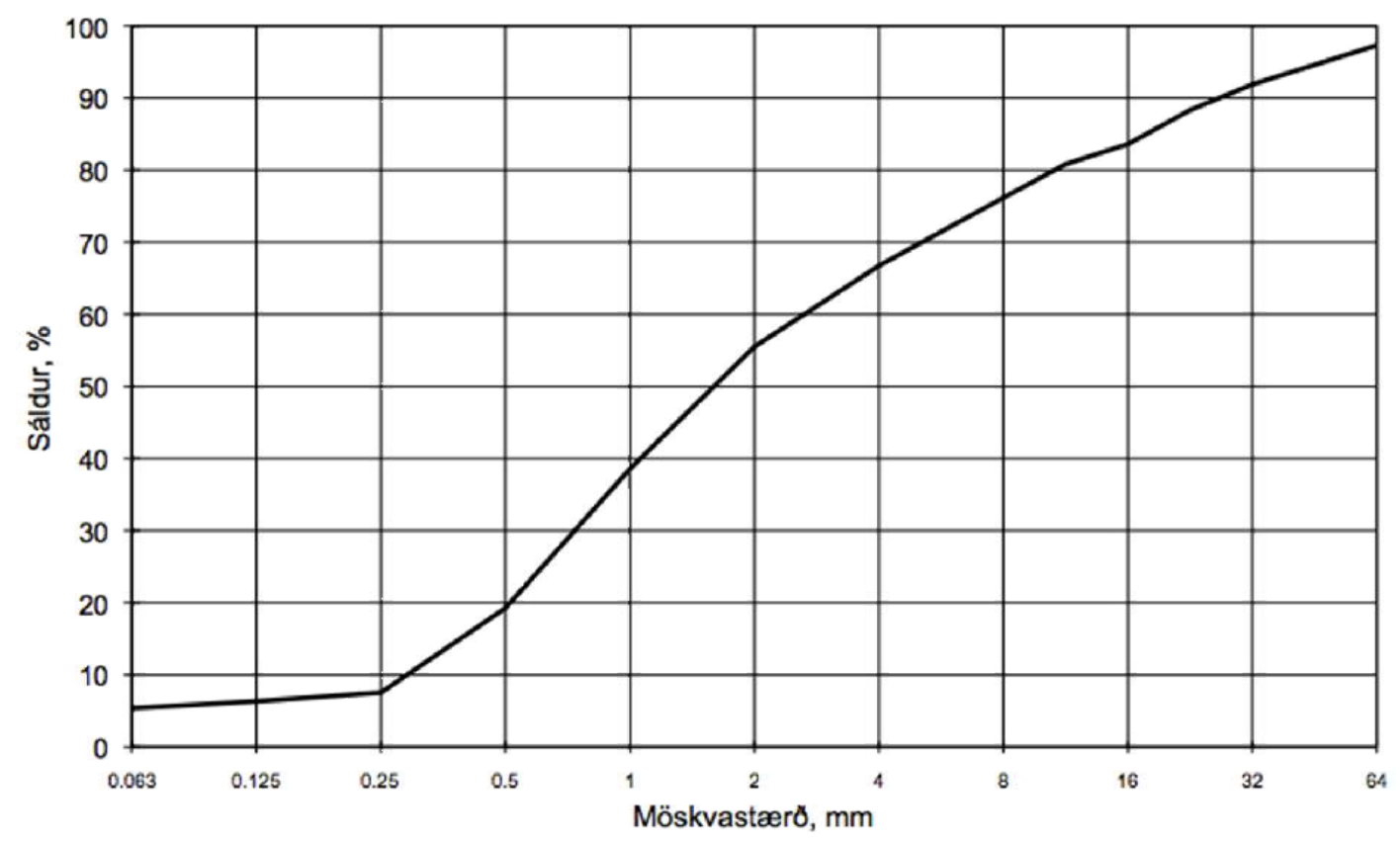

Figure 17 Granulometric curve for cover soil sample from the Fiflholt landfill. Sáldur (\%) = Percent passing (\%), Möskvastcerð $(\mathrm{mm})=$ Sieve size $(\mathrm{mm})$.

Norwegian Public Roads Administration guidelines no. 14.445 was used to determine carbon content via the loss-on-ignition method (LOI). The method involves the destruction of all organic matter in the soil by heating. A known weight of a dry soil sample $(<0.5 \mathrm{~mm})$ was placed in a ceramic crucible which was then heated to $450^{\circ} \mathrm{C}$ for approximately 24 hours. The sample was then put into a desiccator until stabilized, after which it was weighed to determine weight loss. Organic content of the soil sample was calculated as the difference between the initial and final weight divided by the initial weight.

A subset of two samples from the original soil sample were used for the loss-on-ignition test in order to determine organic content of the soil, giving an average value of $7 \%$ organic matter. A discussion on oxidation in materials with different organic matter content can be found in Chapter 2.5.3.

\subsection{Methane Oxidation Assessment}

\subsubsection{Gas Profile Method $\left(\mathrm{CO}_{2} / \mathrm{CH}_{4}\right.$ ratio $)$}

The gas profile method is based on the change in the ratio of $\mathrm{CO}_{2}$ to $\mathrm{CH}_{4}$ in the gas profile, compared to the ratio in the raw landfill gas (Gebert et al, 2011). It is assumed that the change occurs as a result of an oxidation process, i.e. the following reaction:

$$
\mathrm{CH}_{4}+2 \mathrm{O}_{2} \rightarrow \mathrm{CO}_{2}+2 \mathrm{H}_{2} \mathrm{O}
$$

The ratio $\mathrm{CO}_{2}$ to $\mathrm{CH}_{4}$ is higher near the surface, since $\mathrm{CH}_{4}$ gradually gets converted to $\mathrm{CO}_{2}$ in the oxidation process.

The method is based on the following assumptions (Gebert et al., 2011): 



to $1 \mathrm{~mol}$ of $\mathrm{CO}_{2}$.

- It is assumed that that in an established landfill cover the size of the methanotrophic population is stable, i.e. no net transfer of carbon into the microbial biomass.

- It is assumed that the net increase in $\mathrm{CO}_{2}$ is due to oxidation of $\mathrm{CH}_{4}$ only, and that this is valid for conditions where the $\mathrm{CO}_{2} / \mathrm{CH}_{4}$ ratio is mainly controlled by $\mathrm{CH}_{4}$ oxidation, i.e. microbe respiration plays a minor role or can be considered negligible. This applies for biofilters with high $\mathrm{CH}_{4}$ loading and oxidation rates, in daily and temporary landfill covers, and it is assumed that it can be applied for medium sized landfills without gas extractions systems, such as can be found in Iceland.

- The gas phase $\mathrm{CO}_{2}$ is in equilibrium with the liquid phase $\mathrm{CO}_{2}$.

- Precipitation of $\mathrm{CO}_{2}$ is negligible, as is true for non-calcareous soils typical in Iceland

- The system is under steady state.

Given the above assumptions, the method is subject to some limitations, which are discussed in more detail in chapter 5.

It is assumed that the volume of $\mathrm{CO}_{2}$ produced equals the volume of $\mathrm{CH}_{4}$ oxidized, which can be derived from the following equation:

$$
\frac{C O_{2(L F G)}+x}{C H_{4(L F G)}-x}=\frac{C O_{2(i)}}{C H_{4(i)}}
$$

where $x=$ share of oxidized $\mathrm{CH}_{4}(\%)$ at a certain depth i, $\mathrm{CH}_{4(L F G)}=\mathrm{CH}_{4}$ concentration of the landfill gas (\%), $\mathrm{CO}_{2(L F G)}=\mathrm{CO}_{2}$ concentration of the landfill gas (\%), $\mathrm{CH}_{4(i)}=\mathrm{CH}_{4}$ concentration at depth i (\%) and $\mathrm{CO}_{2(i)}=\mathrm{CO}_{2}$ concentration at depth i (\%). From the above assumptions it follows that $\mathrm{CO}_{2(\mathrm{LFG})}=100-\mathrm{CH}_{4(\mathrm{LFG})}$, i.e. other landfill gasses are in trace amounts $(\leq 1 \%)$ and considered negligible (see Chapter 3.3.3).

$\mathrm{CH}_{4(\mathrm{LFG})}$ and $\mathrm{CO}_{2(\mathrm{LFG})}$ values are chosen where $\mathrm{CH}_{4(\mathrm{LFG})}$ concentrations are the highest, sometimes from well measurements and sometimes from the deepest sampling tubes, see Chapter 4.3 .

\subsubsection{Oxidation Efficiency (Eff ${ }_{\text {ox }}$ ) Calculation}

The oxidation efficiency, Eff $f_{o x}$, is obtained by dividing the share of oxidized $\mathrm{CH}_{4}$ at each

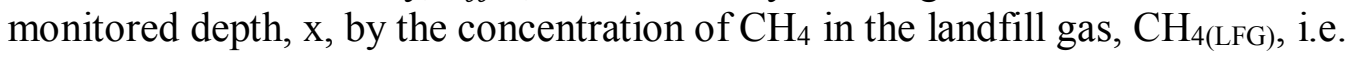

$$
E f f_{o x}=\frac{x}{C H_{4(L F G)}}
$$

In the soil profile, this efficiency represents the cumulative percentage of $\mathrm{CH}_{4}$ oxidized. The higher the efficiency, the more methane oxidized. The method is independent of the nature of the flux (diffusive or advective) of both landfill gas seeping up through the cover and of 
the influx of atmospheric gas from the surface. The method also assumes that $\mathrm{CH}_{4}$ and $\mathrm{CO}_{2}$ are diluted to the same extent in the pore volume by atmospheric gases.

When calculating the oxidation efficiency Effox $(\%)$ at each depth in the soil profile, it is important to take into account the dilution of the biogas generated in the landfill, i.e. its dilution due to the influx of atmospheric gasses, most predominantly $\mathrm{O}_{2}$ and $\mathrm{N}_{2}$. The oxidation efficiency can thus be calculated using the following three steps:

1. Calculate the concentration of non-diluted $\mathrm{CH}_{4}$, i.e. the effective methane concentration $(\%)$ at depth $\mathrm{i}$ :

$$
\text { Non-diluted } \mathrm{CH}_{4(i)}=\mathrm{CH}_{4(i)} \cdot 100 /\left(\mathrm{CH}_{4(i)}+\mathrm{CO}_{2(i)}\right)
$$

where Non-diluted $\mathrm{CH}_{4(i)}$ is the effective methane concentration (\%) of the pore gas at depth i, not taking into account dilution with atmospheric gasses $\mathrm{O}_{2}$ and $\mathrm{N}_{2}$, and $\mathrm{CH}_{4(i)}$ and $\mathrm{CO}_{2(i)}$ are measured methane and carbon dioxide concentrations (\%) at depth $\mathrm{i}$.

2. Calculate oxidized $\mathrm{CH}_{4}(\%)$ at depth $\mathrm{i}$ :

$$
\text { Oxidized } \mathrm{CH}_{4(i)}=x=\mathrm{CH}_{4(L F G)}-\text { Non-diluted } \mathrm{CH}_{4(i)}
$$

where Oxidized $\mathrm{CH}_{4(i)}$ is the share of oxidized $\mathrm{CH}_{4}(\%)$ at depth $\mathrm{i}$ and $\mathrm{CH}_{4(L F G)}$ is the methane concentration of the landfill gas, i.e. the highest measured value of methane before oxidation is assumed to take place, typically measured at a monitoring well, if not then at the $120 \mathrm{~cm}$ tube, see chapter 4.3) The oxidized $\mathrm{CH}_{4}$ could equally be calculated using measured $\mathrm{CO}_{2(L F G)}$, since we assume that $\mathrm{CO}_{2(\mathrm{LFG})}=100-\mathrm{CH}_{4(\mathrm{LFG})}$.

3. Calculate the oxidation efficiency, $\operatorname{Eff}_{\mathrm{ox}}(\%)$, at depth $\mathrm{i}$ :

$$
\text { Eff }_{\text {ox }(i)}=\text { Oxidized } \mathrm{CH}_{4(i)} \cdot 100 / \mathrm{CH}_{4(L F G)}
$$

where $E f f_{o x(i)}$ is the oxidation efficiency (\%) at depth i.

Limitations of this method are discussed in chapter 5. The calculated oxidation efficiency is subject to errors due to assumptions that are assumed to be valid, see Chapter 3.4.1 and due to errors in measurements (equipment and measurement procedure). Calculated oxidation efficiencies can therefore only be assumed to have one or two significant digits. It must be emphasized that calculated efficiencies are neither accurate nor constant values, and that the gas profile method is only intended to give an indication of the efficiency. 


\section{Results}

In the following section, results are presented together for the two locations that were measured at cell 2 of the Fiflholt landfill, C2-N and C2-S. Results include gas profiles, landfill gas concentrations, calculated oxidation efficiencies and an analysis of meteorological data. The results and limitations of the gas profile method among other issues are further discussed in Chapter 5.

\subsection{Gas Profiles}

\subsubsection{General Results and Reliability}

Gas concentration profiles were plotted for each monitoring spot and each sampling date, i.e. a total of 8 gas profiles at $\mathrm{C} 2-\mathrm{N}$, see Figure 18, and 6 gas profiles at C2-S, see Figure 19. The $\mathrm{x}$-axis represents the share of $\mathrm{CH}_{4}, \mathrm{CO}_{2}, \mathrm{O}_{2}$ and $\mathrm{N}_{2}$ in the gas measured at respective probe depth in the top cover, represented by the y-axis. Gas concentrations could only be measured once at the $120 \mathrm{~cm}$ tube at $\mathrm{C} 2-\mathrm{N}$ throughout the entire study period, i.e. in December 2012. On all other occasions, the tube was filled with water. In August 2013, the $40 \mathrm{~cm}$ tube at $\mathrm{C} 2-\mathrm{S}$ was filled with water.

A similar pattern was observed in most profiles, although there is a marked difference between gas profiles at $\mathrm{C} 2-\mathrm{N}$ and $\mathrm{C} 2-\mathrm{S}$, which is discussed in more detail in Chapter 4.4.1. Similarities were particularly observed in profiles at both locations from September, October, November, January and February. What could generally be observed moving up the profile was a decrease in landfill gases $\mathrm{CH}_{4}$ and $\mathrm{CO}_{2}$ and a change in their ratio, i.e. an increasing $\mathrm{CO}_{2} / \mathrm{CH}_{4}$ ratio indicating methane oxidation. Exceptions to this were observed in December at both locations, in August 2012 and in August 2013 at C2-N to some extent.

Zigzag curves were frequently observed in the gas concentration profiles, which would ideally not be expected in gas profiles under controlled circumstances, i.e. constant gas flow rate through a homogeneous cover material. This anomaly was often observed at C2-N (e.g. in September and October) and to a lesser extent at C2-S (e.g. October and December). There is the possibility of preferential pathways being created in the soil cover under specific environmental conditions (e.g. soil moisture, pressure and temperature, see Chapter 2.5), which would explain why some of the shallower tubes had higher methane concentrations than deeper ones, such as the $10 \mathrm{~cm}$ tube at $\mathrm{C} 2-\mathrm{N}$ in October and the $20 \mathrm{~cm}$ tube at $\mathrm{C} 2-\mathrm{S}$ in December. This was also frequently observed at the $40 \mathrm{~cm}$ tube at $\mathrm{C} 2-\mathrm{N}$.

As discussed in Chapter 3.3.3, the shallowest tubes $(5 \mathrm{~cm}, 10 \mathrm{~cm}, 20 \mathrm{~cm})$ were observed to be loose in the ground during some of the wintertime measurements or had risen upwards due to frost heave. Measurements were performed after reinsertion, but the reliability of these measurements can be put into question given the high porosity of the soil and large variability in concentrations measured. There is the possibility that results from the top 40 $\mathrm{cm}$ were highly influenced by the infiltration of atmospheric air, resulting in diluted concentrations of $\mathrm{CH}_{4}$ and $\mathrm{CO}_{2}$.

Measurement techniques were not yet quite established in August 2012, at the beginning of the study period. Unlike all subsequent measuring dates, gas samples were only extracted once from each sampling tube in August 2012 (see Chapter 3.3.3). Results obtained on this 
sampling date at $\mathrm{C} 2-\mathrm{N}$ can therefore not be considered reliable, especially in light of near atmospheric concentrations of $\mathrm{N}_{2}$ and $\mathrm{O}_{2}$ at the deeper tubes. This does not however invalidate the results, as the profile can give an idea of the ratio between gases and does not rule out high aeration and very good oxidation on this date.

\subsubsection{Atmospheric Air Penetration}

The concentration of nitrogen, $\mathrm{N}_{2}$, can be used as an indicator for assessing the extent of aeration since, contrary to oxygen, $\mathrm{N}_{2}$ is not produced or consumed in the cover, neither during respiration nor the methane oxidation process. $\mathrm{N}_{2}$ can therefore be regarded as an inert tracer for the presence of atmospheric gas. For both locations $\mathrm{C} 2-\mathrm{N}$ and $\mathrm{C} 2-\mathrm{S}$ it was observed that atmospheric gases $\mathrm{O}_{2}$ and $\mathrm{N}_{2}$ were in significant concentrations at $80 \mathrm{~cm}$ (up to $15 \% \mathrm{O}_{2}$ and $70 \% \mathrm{~N}_{2}$ ), but generally zero at $120 \mathrm{~cm}$ depth. This suggests that atmospheric gases penetrate deep into the soil cover. The penetration was not as expressed in December 2012 , when $\mathrm{O}_{2}$ was $<3 \%$ from $10 \mathrm{~cm}$ depth, and $\mathrm{N}_{2}$ was $8 \%$ at $80 \mathrm{~cm}$ depth.

At $\mathrm{C} 2-\mathrm{S}, \mathrm{N}_{2}$ concentrations were in the range of $40-68 \%$ at $80 \mathrm{~cm}$ depth and in the range of $0-11 \%$ at $120 \mathrm{~cm}$ depth, whereas atmospheric $\mathrm{N}_{2}$ was typically $78 \%$. At $\mathrm{C} 2-\mathrm{N}, \mathrm{N}_{2}$ was measured in the range of $32-73 \%$ at $80 \mathrm{~cm}$ depth, except in December 2012 when it was $8 \%$, and $28 \%$ at $120 \mathrm{~cm}$ depth, the only time the tube wasn't filled with water. The data indicates that air penetrates slightly deeper into the cover at C2-N than at C2-S. Since the presence of oxygen is necessary for the oxidation process, this indicates that microbial methane oxidation can take place deep in the cover soil, probably slightly deeper at $\mathrm{C} 2-\mathrm{N}$ than at $\mathrm{C} 2-$ $\mathrm{S}$. This is confirmed by the fact that the proportion of $\mathrm{O}_{2}$ to $\mathrm{N}_{2}$ decreased with depth, indicating microbial $\mathrm{O}_{2}$ consumption, and is slightly more pronounced at $\mathrm{C} 2-\mathrm{N}$ than at $\mathrm{C} 2-$ S.

The deep penetration of atmospheric air indicates a high pore volume of the soil. This is confirmed by the soil analysis of the top cover, detailed in Chapter 3.3.7, where the size distribution curve exhibited a poorly graded gravely sand. The wide range of size particles and poor gradation results in a very porous media, facilitating gas migration of both atmospheric and landfill gases depending on the degree of saturation. Wind might also be an important contributor to the deep ingress of atmospheric air.

\subsubsection{Oxidation Horizon}

In a landfill gas profile, there is an optimum zone for methane oxidation where oxygen, methane and environmental conditions such as temperature and moisture promote methanotrophic growth. This zone is generally referred to as the oxidation horizon or oxidation front, and its depth varies not only for each individual landfill, but also within the same cell, due to high heterogeneity within both waste and top cover. In a gas concentration profile, this zone is often identified where the $\mathrm{CH}_{4}$ and $\mathrm{CO}_{2}$ profiles converge and the $\mathrm{CO}_{2} / \mathrm{CH}_{4}$ ratio increases when approaching the surface.

At $\mathrm{C} 2-\mathrm{N}, \mathrm{CH}_{4}$ and $\mathrm{CO}_{2}$ profiles converged at or below $80 \mathrm{~cm}$ depth, indicating an oxidation horizon to depths even below $80 \mathrm{~cm}$, possibly right from the bottom of the top cover. Exceptions to this at C2-N were in December in August 2013, when little or no change in the $\mathrm{CO}_{2} / \mathrm{CH}_{4}$ ratio was observed, indicating little or no oxidation throughout the profile. 

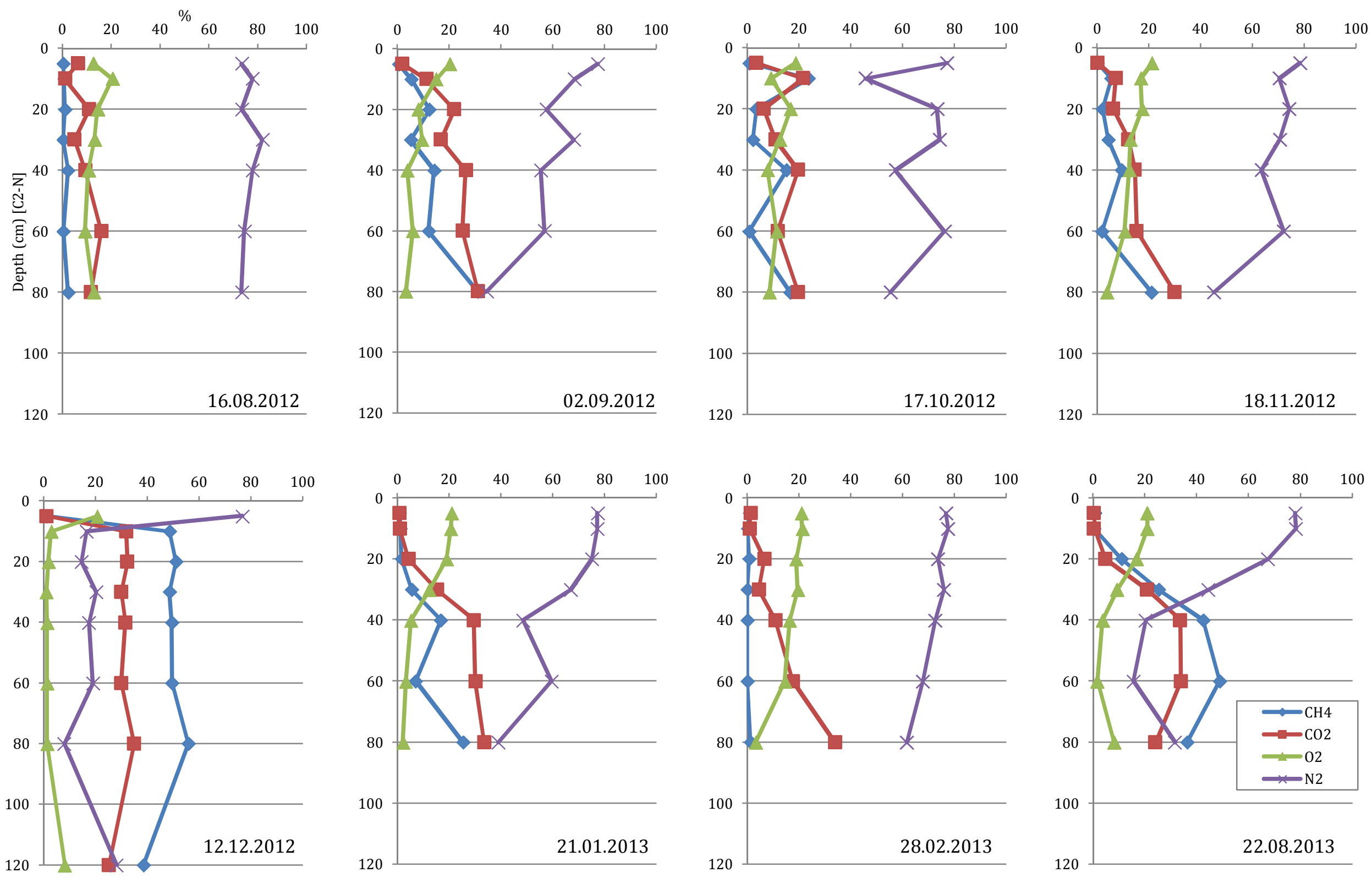

Figure 18 Gas concentration profiles (\% v/v) for C2-N during the study period, from August 2012 to August 2013. 

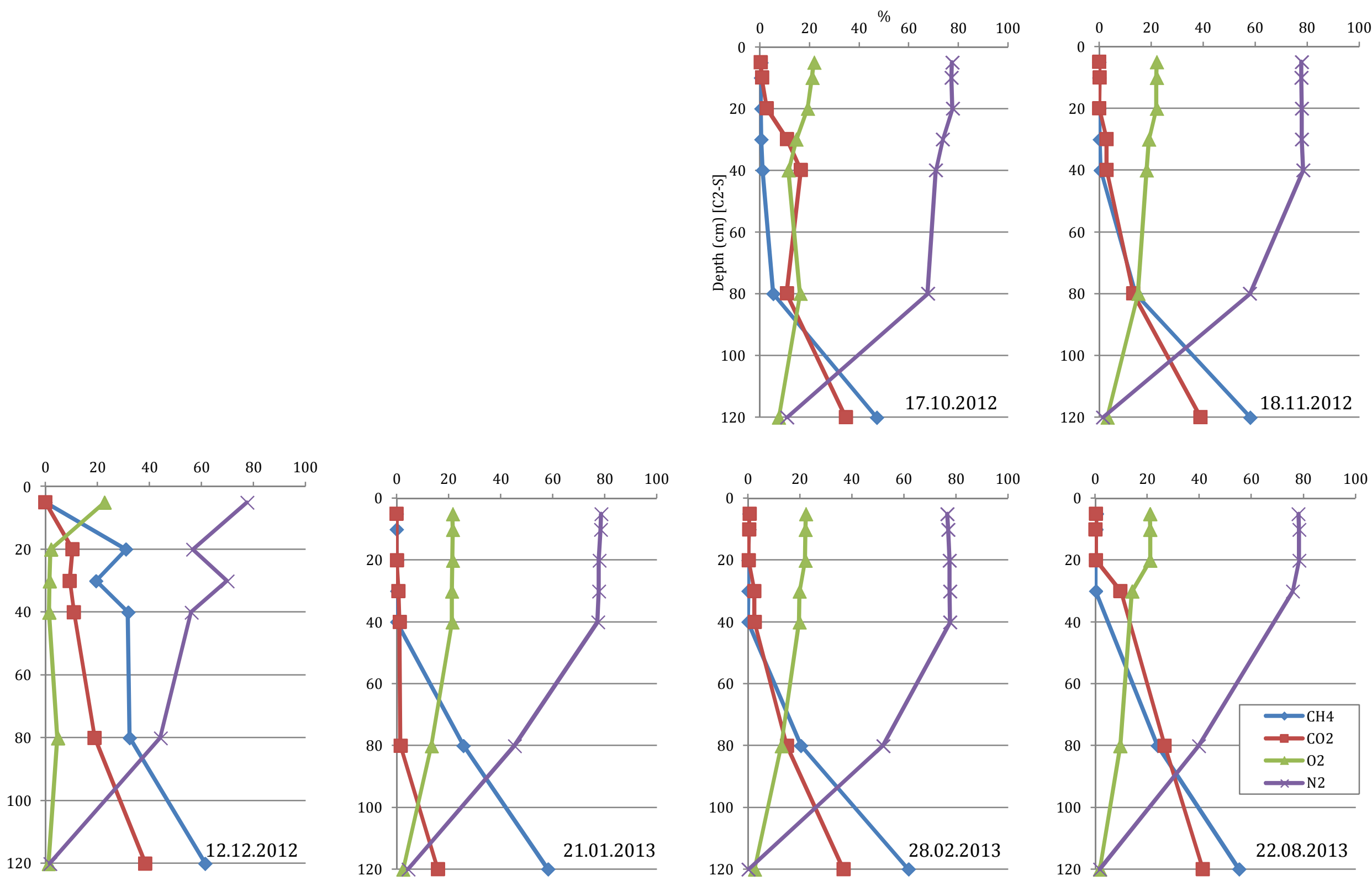

Figure 19 Gas concentration profiles (\% v/v) for C2-S during the study period, from August 2012 to August 2013. 
At $\mathrm{C} 2-\mathrm{S}, \mathrm{CH}_{4}$ and $\mathrm{CO}_{2}$ profiles converged at shallower depths than at $\mathrm{C} 2-\mathrm{N}$, or mainly between $40 \mathrm{~cm}$ and $90 \mathrm{~cm}$ depths. Again, an exception was observed in December, where despite an even deeper penetration of atmospheric air into the soil than at $\mathrm{C} 2-\mathrm{N}$, little or no change was observed in the $\mathrm{CO}_{2} / \mathrm{CH}_{4}$ ratio, indicating little or no oxidation. Overall, the oxidation zone seems to be situated below $40 \mathrm{~cm}$ depth at $\mathrm{C} 2-\mathrm{S}$, seemingly starting at the base of the top cover. In a recent study on a landfill in Québec $\left(72^{\circ} \mathrm{N}\right)$, the oxidation zone was also established from the base of the biocover substrate material (sand and compost), or between depths 0.6-0.8 $\mathrm{m}$ (Cabral et al., 2010a).

\subsection{Landfill Gas Concentration}

During this study, gas concentrations were measured from wells at $\mathrm{C} 2-\mathrm{S}$ and $\mathrm{C} 2-\mathrm{N}$ on 5 occasions, see Table 7. Methane concentrations were in ranges $52-59 \%$ at $\mathrm{C} 2-\mathrm{S}$ and $38-58 \%$ at $\mathrm{C} 2-\mathrm{N}$. This is consistent with prior measurements presented in Chapter 3.3.4. Aside from the two lower $\mathrm{CH}_{4}$ concentrations measured at C2-N in January and August 2013, the gas concentrations are typical of landfill gas in active phase.

Concentrations of $\mathrm{N}_{2}$, which serves as a tracer being neither produced nor consumed, were relatively high at C2-N, especially in January and August 2013. This might be the result of air intrusion through cracks or fissures along the well or through cracks in the top cover. The borehole walls of the well were sealed with bentonite at the top during installation in 2009 . There is a possibility that this seal has broken as a result of settlement of the cover since installation, i.e. after about 3 years, and/or harsh weather conditions, especially freeze and thaw cycles. High $\mathrm{N}_{2}$ concentrations were also measured at $\mathrm{C} 2-\mathrm{N}$ in 2011, see Table 6 in Chapter 3.3.4, but not in 2010 .

Table 7 A summary of gas concentrations in monitoring wells at C2-S and C2-N measured at the Fiflholt landfill during this study.

\begin{tabular}{|l|r|r|r|r|r|r|r|r|}
\hline \multirow{2}{*}{ Date } & \multicolumn{9}{|c|}{$\mathrm{C} 2-\mathrm{S}$} & \multicolumn{3}{c|}{$\mathrm{C} 2-\mathrm{N}$} \\
\cline { 2 - 10 } & $\mathrm{CH}_{4}(\%)$ & $\mathrm{CO}_{2}(\%)$ & $\mathrm{O}_{2}(\%)$ & $\mathrm{N}_{2}(\%)$ & $\mathrm{CH}_{4}(\%)$ & $\mathrm{CO}_{2}(\%)$ & $\mathrm{O}_{2}(\%)$ & $\mathrm{N}_{2}(\%)$ \\
\hline 02.09 .2012 & 56.9 & 42.4 & 0.4 & 0.3 & - & - & - & - \\
\hline 17.10 .2012 & 55.8 & 44.0 & 0.2 & 0 & 51.4 & 41.1 & 0.9 & 7.1 \\
\hline 21.01 .2013 & 56.7 & 43.2 & 0.1 & 0 & 37.8 & 27.8 & 8.3 & 26.1 \\
\hline 28.02 .2013 & 51.9 & 39.8 & 0.5 & 7.8 & 57.6 & 33.5 & 0.8 & 8.1 \\
\hline 22.08 .2013 & 58.9 & 40.7 & 0.4 & 0 & 46.9 & 39.5 & 0.4 & 13.2 \\
\hline Average & 56.0 & 42.0 & 0.3 & 1.6 & 48.4 & 35.5 & 2.6 & 13.6 \\
\hline STD & 2.6 & 1.7 & 0.2 & 3.5 & 8.3 & 6.1 & 3.8 & 8.7 \\
\hline
\end{tabular}

According to concentration values obtained during the period of this study, the well at C2-S seems to be intact, exhibiting typical landfill gas values. In February 2013, however, higher $\mathrm{N}_{2}$ values were measured, indicating air penetration such as observed at $\mathrm{C} 2-\mathrm{N} . \mathrm{O}_{2}$ concentrations are high in January 2013 at $\mathrm{C} 2-\mathrm{N}$, in accordance with high $\mathrm{N}_{2}$ values. Low $\mathrm{O}_{2}$ values paired with relatively high $\mathrm{N}_{2}$ suggest microbial consumption of $\mathrm{O}_{2}$.

The intrusion of atmospheric air through the leachate collection system is unlikely, as locations C2-N and C2-S are situated about $200 \mathrm{~m}$ and $100 \mathrm{~m}$ away from nearest wells, respectively. There are no other apparent ways of entry for atmospheric air, except along wells or through the cover. 


\subsection{Methane Oxidation Efficiency}

Using the methodology described in Chapter 3.4.2, oxidation efficiencies were calculated from measured $\mathrm{CH}_{4}$ and $\mathrm{CO}_{2}$ concentrations at each depth, including well measurements. All results and calculations are provided in Appendix A. An example of Eff ox $_{\text {calculations }}$ can be seen in Table 8 and a summary of results is presented in Table 9. The oxidation efficiency in the soil profile is shown in Figure 20 and Figure 21 for locations C2-S and C$\mathrm{N}$, respectively, including the average oxidation efficiency profile for the entire study period at each location. When methane concentrations were $0 \%$, oxidation efficiency values and $\mathrm{CO}_{2} / \mathrm{CH}_{4}$ ratios could not be calculated. Also, when certain tubes were filled with water and gas concentrations could not be measured, no Eff $_{\text {ox }}$ values or ratios were calculated at that depth.

When calculating Eff ${ }_{\mathrm{ox}}$, the highest measured concentration of $\mathrm{CH}_{4}$ measured during each sampling date was used, sometimes measured at well depth (3-5 m), sometimes at the deeper tubes $(60-120 \mathrm{~cm})$, see Appendix A. When the highest methane concentrations measured were $\leq 45 \%$ ( 4 occasions at $\mathrm{C} 2-\mathrm{N})$, a default value of $55 \%$ was used to calculate Eff ox. This was done for two reasons; 1) in January 2013, when measurements from the well and 120 $\mathrm{cm}$ tube at $\mathrm{C} 2-\mathrm{N}$ indicated atmospheric intrusion while $\mathrm{CH}_{4}$ concentrations at the $\mathrm{C} 2-\mathrm{S}$ well was 57\%, and 2) in August, September and November 2012, when there were no available $\mathrm{CH}_{4}$ values from the well or $120 \mathrm{~cm}$ tube, and $\mathrm{CH}_{4}$ concentrations at the $\mathrm{C} 2-\mathrm{S}$ well or 120 $\mathrm{cm}$ tube exhibited typical landfill gas values.

Table 8 Example of Effox calculations, using gas concentration values measured at sampling tubes and monitoring well at C2-S on February 28, 2013. All results and calculations can be seen in Appendix A.

\begin{tabular}{|r|c|c|c|c|c|c|c|c|}
\hline $\begin{array}{c}\text { Depth } \\
(\mathrm{cm})\end{array}$ & $\begin{array}{c}\mathrm{CH}_{4} \\
(\%)\end{array}$ & $\begin{array}{c}\mathrm{CO}_{2} \\
(\%)\end{array}$ & $\begin{array}{c}\mathrm{O}_{2} \\
(\%)\end{array}$ & $\begin{array}{c}\mathrm{N}_{2} \\
(\%)\end{array}$ & $\begin{array}{c}\text { Ratio } \\
\mathrm{CO}_{2} / \mathrm{CH}_{4}\end{array}$ & $\begin{array}{c}\text { Non-diluted } \\
\mathrm{CH}_{4}(\%)\end{array}$ & $\begin{array}{c}\text { Oxidized } \mathrm{CH}_{4} \\
(\%)\end{array}$ & $\begin{array}{c}\mathrm{Eff} \\
(\%)\end{array}$ \\
\hline 5 & 0.47 & 0.63 & 22.27 & 76.63 & 1.4 & 42.4 & 19.2 & 31.2 \\
\hline 10 & 0.48 & 0.43 & 22.15 & 76.95 & 0.9 & 52.8 & 8.9 & 14.4 \\
\hline 20 & 0.18 & 0.25 & 22.05 & 77.50 & 1.4 & 41.2 & 20.5 & 33.2 \\
\hline 30 & 0.17 & 2.47 & 19.77 & 77.60 & 14.8 & 6.3 & 55.3 & 89.7 \\
\hline 40 & 0.08 & 2.56 & 19.70 & 77.66 & 32.0 & 3.0 & 58.6 & 95.1 \\
\hline 80 & 20.33 & 14.97 & 12.80 & 51.93 & 0.7 & 57.6 & 4.1 & 6.6 \\
\hline 120 & $61.67 *$ & 36.70 & 2.57 & 0.13 & 0.6 & 62.7 & -1.0 & -1.7 \\
\hline $3-5 \mathrm{~m}$ & 51.90 & 39.80 & 0.50 & 7.80 & 0.8 & 56.6 & 5.1 & 8.2 \\
\hline
\end{tabular}

* maximum value measured during sampling date at C2-S, used to calculate $\mathrm{Eff}_{\text {ox. }}$.

Typical concentrations of methane and carbon dioxide in landfill gas are 55-60\% $\mathrm{CH}_{4}$ and $40-45 \% \mathrm{CO}_{2}$ (Scheutz et al., 2009). The ratio of $\mathrm{CO}_{2}$ to $\mathrm{CH}_{4}$ in landfill gas is therefore between 0.67 and 0.82 . When microbial oxidation takes place, see chapter 3.4 , this ratio increases as $\mathrm{CH}_{4}$ is being consumed, producing $\mathrm{CO}_{2}$ (Gebert et al., 2011). It can be helpful to observe this ratio in parallel with oxidation efficiencies, as high ratios usually indicate oxidation activity. The change in this ratio is however only an indicator of oxidation if there is no other significant source for $\mathrm{CO}_{2}$, such as soil respiration, which we assume to be the case. In Table 8 , high $\mathrm{CO}_{2} / \mathrm{CH}_{4}$ ratios conform well to calculated oxidation efficiencies at 40 and $30 \mathrm{~cm}$ depth. All other $\mathrm{CO}_{2} / \mathrm{CH}_{4}$ ratios are provided in Appendix A. 
Table 9 A summary of methane and carbon dioxide concentrations and calculated oxidation efficiencies for each tube depth at C2-N and C2-S during the study. All results and calculations are provided in Appendix A.

\begin{tabular}{|c|c|c|c|c|c|c|c|c|c|c|}
\hline \multirow{2}{*}{ Date } & & & \multicolumn{8}{|c|}{ Depth $(\mathrm{cm})$} \\
\hline & & & 5 & 10 & 20 & 30 & 40 & 60 & 80 & 120 \\
\hline \multirow{3}{*}{16.08 .2012} & \multirow{3}{*}{$\mathrm{C} 2-\mathrm{N}$} & $\mathrm{CH}_{4}(\%)$ & 0.30 & 0.70 & 1.10 & 0.30 & 2.30 & 0.40 & 2.40 & \multirow{3}{*}{ N.A } \\
\hline & & $\mathrm{CO}_{2}(\%)$ & 6.30 & 1.10 & 10.90 & 4.90 & 9.30 & 15.90 & 11.70 & \\
\hline & & $\mathrm{Eff}_{\mathrm{ox}}(\%)$ & 91.7 & 29.3 & 83.3 & 89.5 & 63.9 & 95.5 & 69.1 & \\
\hline \multirow{3}{*}{02.09 .2012} & \multirow{3}{*}{$\mathrm{C} 2-\mathrm{N}$} & $\mathrm{CH}_{4}(\%)$ & 0.60 & 5.50 & 12.40 & 5.20 & 14.20 & 12.10 & 31.10 & \multirow{3}{*}{ N.A. } \\
\hline & & $\mathrm{CO}_{2}(\%)$ & 1.90 & 11.20 & 21.90 & 16.80 & 26.40 & 25.20 & 31.10 & \\
\hline & & $\mathrm{Eff}_{\mathrm{ox}}(\%)$ & 56.4 & 40.1 & 34.3 & 57.0 & 36.4 & 41.0 & 9.1 & \\
\hline \multirow{6}{*}{17.10 .2012} & \multirow{3}{*}{$\mathrm{C} 2-\mathrm{N}$} & $\mathrm{CH}_{4}(\%)$ & 0.80 & 23.70 & 3.57 & 2.17 & 15.20 & 0.77 & 16.50 & \multirow{3}{*}{ N.A. } \\
\hline & & $\mathrm{CO}_{2}(\%)$ & 3.55 & 21.60 & 6.33 & 10.83 & 19.67 & 11.73 & 19.66 & \\
\hline & & $\mathrm{Eff}_{\mathrm{ox}}(\%)$ & 64.2 & -1.8 & 29.9 & 67.6 & 15.2 & 88.1 & 11.2 & \\
\hline & \multirow{3}{*}{ C2-S } & $\mathrm{CH}_{4}(\%)$ & 0.40 & 0.37 & 0.43 & 0.57 & 1.05 & & 5.35 & 47.00 \\
\hline & & $\mathrm{CO}_{2}(\%)$ & 0.35 & 0.83 & 2.73 & 10.97 & 16.45 & & 10.80 & 34.60 \\
\hline & & $\mathrm{Eff}_{\mathrm{ox}}(\%)$ & 4.4 & 45.2 & 75.5 & 91.2 & 89.2 & & 40.6 & -3.2 \\
\hline \multirow{6}{*}{ 18.11.2012 } & \multirow{3}{*}{$\mathrm{C} 2-\mathrm{N}$} & $\mathrm{CH}_{4}(\%)$ & 0.17 & 5.50 & 2.13 & 4.38 & 9.50 & 1.91 & 21.02 & \multirow{3}{*}{ N.A. } \\
\hline & & $\mathrm{CO}_{2}(\%)$ & 0.33 & 7.37 & 6.30 & 12.20 & 14.70 & 15.41 & 29.96 & \\
\hline & & Eff $_{\text {ox }}(\%)$ & 39.4 & 22.3 & 54.0 & 52.0 & 28.6 & 79.9 & 25.0 & \\
\hline & \multirow{3}{*}{ C2-S } & $\mathrm{CH}_{4}(\%)$ & 0.00 & 0.00 & 0.00 & 0.15 & 0.50 & & 13.97 & 58.03 \\
\hline & & $\mathrm{CO}_{2}(\%)$ & 0.10 & 0.30 & 0.10 & 2.89 & 2.89 & & 13.22 & 39.00 \\
\hline & & $\mathrm{Eff}_{\mathrm{ox}}(\%)$ & 100.0 & 100.0 & 100.0 & 91.5 & 74.6 & & 11.4 & -3.1 \\
\hline \multirow{6}{*}{12.12 .2012} & \multirow{3}{*}{$\mathrm{C} 2-\mathrm{N}$} & $\mathrm{CH}_{4}(\%)$ & 1.30 & 48.56 & 51.06 & 48.63 & 49.50 & 49.58 & 55.80 & 38.48 \\
\hline & & $\mathrm{CO}_{2}(\%)$ & 1.20 & 32.00 & 32.44 & 30.01 & 31.62 & 29.98 & 34.94 & 25.22 \\
\hline & & $\mathrm{Eff}_{\mathrm{ox}}(\%)$ & 6.8 & -8.0 & -9.6 & -10.8 & -9.4 & -11.7 & -10.2 & -8.3 \\
\hline & \multirow{3}{*}{ C2-S } & $\mathrm{CH}_{4}(\%)$ & 0.00 & \multirow{3}{*}{ N.A. } & 30.94 & 19.43 & 31.73 & & 32.33 & 61.32 \\
\hline & & $\mathrm{CO}_{2}(\%)$ & 0.00 & & 10.44 & 9.33 & 10.93 & & 18.90 & 38.35 \\
\hline & & $\mathrm{Eff}_{\mathrm{ox}}(\%)$ & - & & -21.9 & -10.2 & -21.3 & & -2.9 & -0.3 \\
\hline \multirow{6}{*}{21.01 .2013} & & $\mathrm{CH}_{4}(\%)$ & 0.90 & 1.23 & 1.63 & 5.55 & 16.77 & 7.05 & 25.38 & \multirow{3}{*}{ N.A } \\
\hline & $\mathrm{C} 2-\mathrm{N}$ & $\mathrm{CO}_{2}(\%)$ & 0.82 & 0.98 & 4.33 & 15.25 & 29.57 & 30.13 & 33.50 & \\
\hline & & $\mathrm{Eff}_{\mathrm{ox}}(\%)$ & 6.8 & -1.8 & 73.1 & 74.9 & 49.8 & 95.3 & 31.5 & \\
\hline & & $\mathrm{CH}_{4}(\%)$ & 0.00 & 0.00 & 0.05 & 0.05 & 0.05 & & 25.63 & 58.08 \\
\hline & $\mathrm{C} 2-\mathrm{S}$ & $\mathrm{CO}_{2}(\%)$ & 0.00 & 0.05 & 0.70 & 1.15 & 1.48 & & 15.80 & 35.68 \\
\hline & & $\mathrm{Eff}_{\mathrm{ox}}(\%)$ & - & 100.0 & 88.5 & 92.8 & 94.4 & & -6.5 & -6.7 \\
\hline & & $\mathrm{CH}_{4}(\%)$ & 0.97 & 0.23 & 0.80 & 0.10 & 0.10 & 0.10 & 1.33 & \\
\hline & $\mathrm{C} 2-\mathrm{N}$ & $\mathrm{CO}_{2}(\%)$ & 1.30 & 0.98 & 6.67 & 4.50 & 10.90 & 17.60 & 33.88 & N.A. \\
\hline 280132013 & & Eff $_{\text {ox }}(\%)$ & 26.0 & 67.4 & 81.4 & 96.2 & 98.4 & 99.0 & 93.5 & \\
\hline 28.02 .2013 & & $\mathrm{CH}_{4}(\%)$ & 0.47 & 0.48 & 0.18 & 0.17 & 0.08 & & 20.33 & 61.67 \\
\hline & C2-S & $\mathrm{CO}_{2}(\%)$ & 0.63 & 0.43 & 0.25 & 2.47 & 2.56 & & 14.97 & 36.70 \\
\hline & & $\mathrm{Eff}_{\mathrm{ox}}(\%)$ & 31.2 & 14.4 & 33.2 & 89.7 & 95.1 & & 6.6 & -1.7 \\
\hline & & $\mathrm{CH}_{4}(\%)$ & 0.65 & 0.38 & 10.95 & 25.24 & 42.45 & 48.84 & 36.21 & \\
\hline & $\mathrm{C} 2-\mathrm{N}$ & $\mathrm{CO}_{2}(\%)$ & 0.40 & 0.40 & 4.78 & 20.98 & 33.65 & 33.96 & 24.11 & N.A. \\
\hline 2080120 & & $\mathrm{Eff}_{\mathrm{ox}}(\%)$ & -26.7 & 0.9 & -42.6 & -11.8 & -14.2 & -20.8 & -22.9 & \\
\hline 22.08 .2013 & & $\mathrm{CH}_{4}(\%)$ & 0.52 & 0.30 & 0.17 & 0.15 & & & 23.86 & 55.20 \\
\hline & $\mathrm{C} 2-\mathrm{S}$ & $\mathrm{CO}_{2}(\%)$ & 0.44 & 0.25 & 0.33 & 9.78 & N.A. & & 26.71 & 41.40 \\
\hline & & $\mathrm{Eff}_{\mathrm{ox}}(\%)$ & 8.0 & 7.4 & 43.4 & 97.4 & & & 19.9 & 3.0 \\
\hline
\end{tabular}




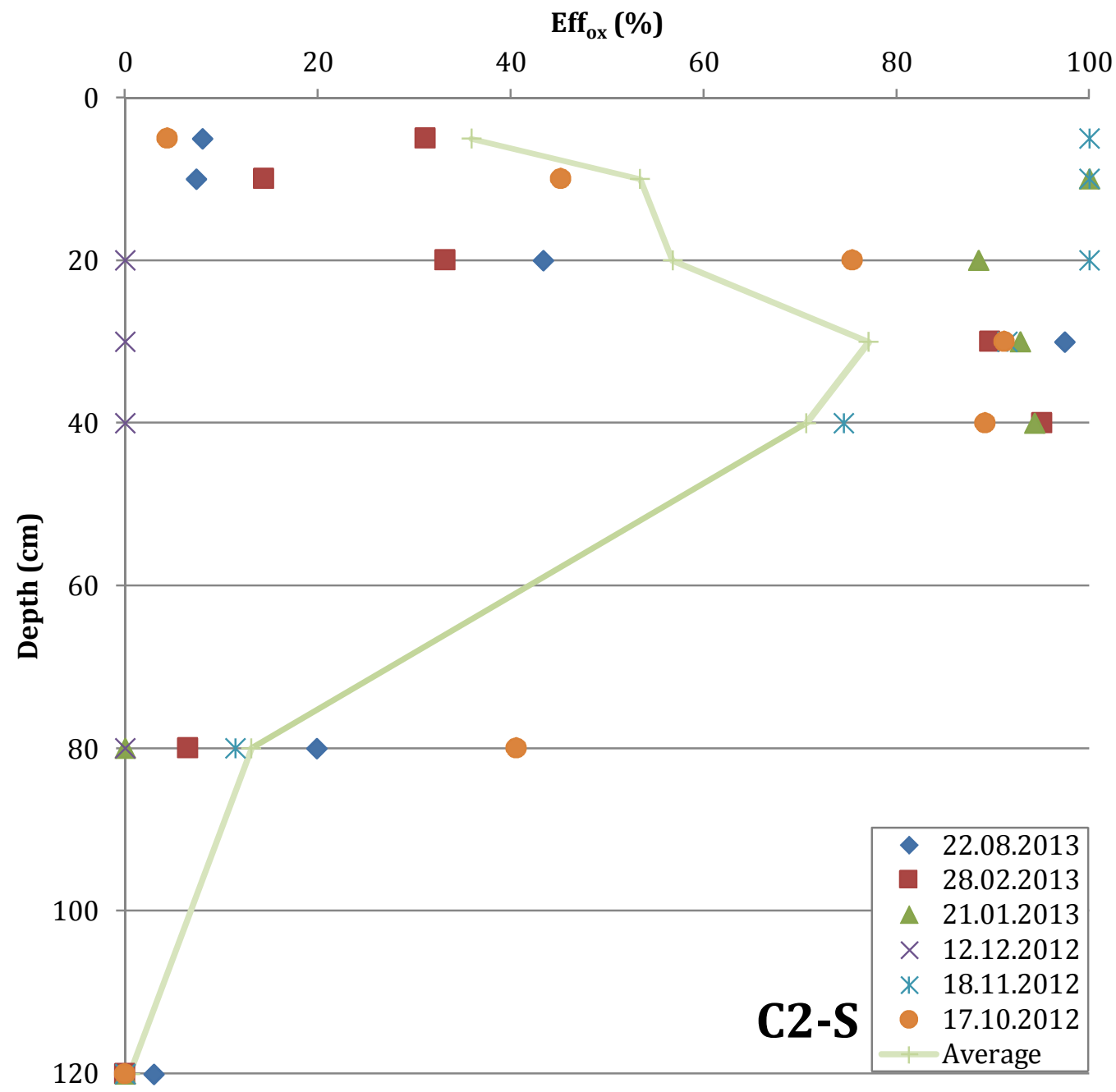

Figure 20 An overview of oxidation efficiencies Eff ox $v$ s. corresponding depths during the study period at C2$S$. Negative Eff ox values, qualitatively equal to 0, are situated on the y-axis.

Table 10 A summary of maximum oxidation efficiency values, Effor, at corresponding depths for both monitoring spots, $C 2-S$ and $C 2-N$.

\begin{tabular}{|l|l|l|l|l|}
\hline \multirow{2}{*}{ Date } & \multicolumn{2}{|c|}{ C2-S } & \multicolumn{2}{c|}{ C2-N } \\
\cline { 2 - 5 } & Depth $(\mathrm{cm})$ & Eff $_{\text {ox }}(\%)$ & Depth $(\mathrm{cm})$ & Eff $_{\text {ox }}(\%)$ \\
\hline 22.08 .2013 & 30 & 97.4 & $0($ neg $)$ & $0($ neg) \\
\hline 28.02 .2013 & 40 & 95.1 & 60 & 99.0 \\
\hline 21.01 .2013 & 40 & 94.4 & 60 & 65.5 \\
\hline 12.12 .2012 & $0($ neg) & $0($ neg $)$ & $0($ neg $)$ & $0($ neg) \\
\hline 18.11 .2012 & 30 & 91.5 & 60 & 79.9 \\
\hline 17.10 .2012 & 30 & 91.2 & 60 & 88.1 \\
\hline 02.09 .2012 & & & $60(30)$ & $41(57)$ \\
\hline 16.08 .2012 & & & 60 & 95.5 \\
\hline
\end{tabular}




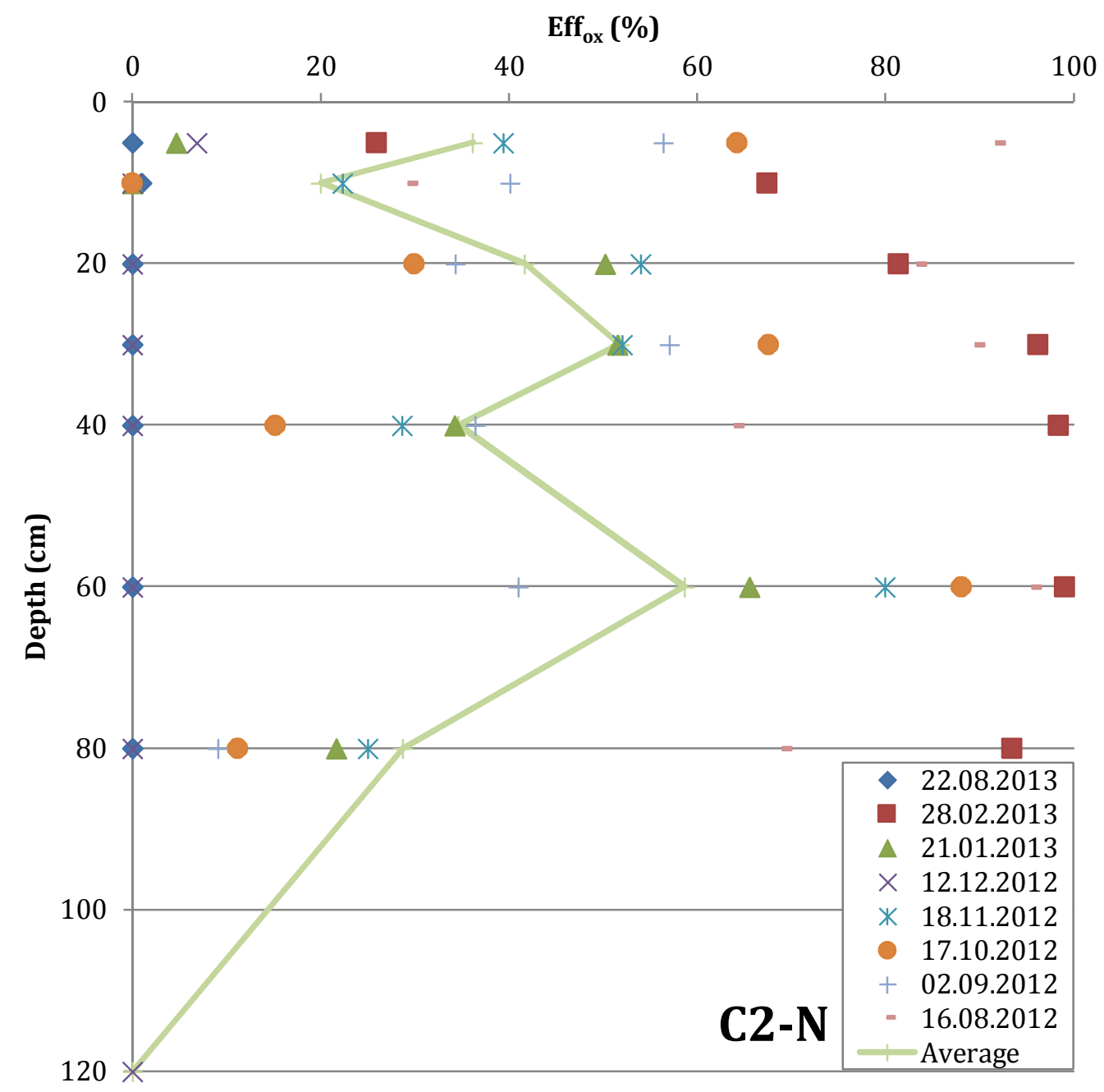

Figure 21 An overview of oxidation efficiencies Effox vs. corresponding depths during the study period at C2$N$. Negative Effox values, qualitatively equal to 0, are situated on the y-axis.

In Figure 20 and in Figure 21, what was generally observed was an increase in the oxidation efficiency moving up the profile before reaching a maximum value between $30 \mathrm{~cm}$ and 60 $\mathrm{cm}$ depth. This indicates that active methane oxidation was taking place in the soil and that the majority of methane had been oxidized about half way through the cover. A summary of maximum Eff ${ }_{0 x}$ values and their corresponding depths for each sampling date is presented in Table 10 for both monitoring spots, C2-S and C2-N. Effox values were the highest at 30 $40 \mathrm{~cm}$ depth at $\mathrm{C} 2-\mathrm{S}$, and at around $60 \mathrm{~cm}$ depth at $\mathrm{C} 2-\mathrm{N}$.

As Table 9 shows, oxidation efficiency values ranged from 0 to $99 \%$. In some cases, negative values of $\mathrm{Eff}_{\mathrm{ox}}$ were calculated. In reality, this is not the case, as methane is not being generated in the soil cover. A negative outcome is the result of the effective $\mathrm{CH}_{4}$ concentration (non-diluted) being higher than the reference landfill gas value, i.e. the highest measured $\mathrm{CH}_{4}$ concentration. This occurred e.g. in December, when high $\mathrm{CH}_{4}$ concentrations were measured close to the surface and there was little to no visible change in the ratio $\mathrm{CO}_{2} / \mathrm{CH}_{4}$, indicating that there was no oxidation taking place, only dilution with atmospheric air. This dilution appeared to be slightly more expressed for $\mathrm{CO}_{2}$ than for $\mathrm{CH}_{4}$, resulting in a negative Effox value. Negative values were also obtained occasionally at $\mathrm{C} 2-\mathrm{N}$ 
due to the default $55 \% \mathrm{CH}_{4}$ reference concentration used to calculate $\mathrm{Eff}_{\mathrm{ox}}$, explained in the beginning of this section. Increasing this default value to e.g. $60 \%$ only decreases the

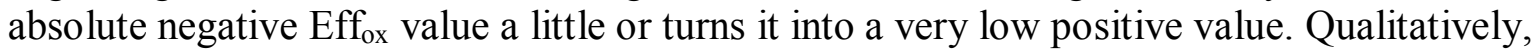
negative values are equal to 0 , i.e. no oxidation is taking place. When calculating average efficiency profiles, negative Eff $_{\text {ox }}$ values were set to 0 .

In Figure 20 and in Figure 21, a loss of efficiency was commonly observed in the shallowest tubes at both locations, i.e. from depth $40 \mathrm{~cm}$ and upward towards the surface. Instinctively, one would not expect a drop in oxidation efficiency, as the oxidation process is not retroactive. Since $\mathrm{CH}_{4}$ concentrations decreased continually towards the top of the cover and generally stayed very low in the top $40 \mathrm{~cm}$ (typically $<1 \%$ at $\mathrm{C} 2-\mathrm{S}$ and $<15 \%$ at $\mathrm{C} 2-\mathrm{N}$ ), see Chapter 4.1, the drop in efficiency seems to be a result of rapid $\mathrm{CO}_{2}$ dilution by atmospheric air, skewing the $\mathrm{CO}_{2} / \mathrm{CH}_{4}$ ratio and thus the efficiency calculation. The dilution is due to a highly porous cover and a probably increased diffusive ability of the soil, the soil becoming less saturated as gas migrates towards the surface. Wind and specific wind directions might also be a factor of influence. Measurements at the top $40 \mathrm{~cm}$ were in other words highly influenced by the intrusion of atmospheric air and the results in the top $40 \mathrm{~cm}$ must therefore be interpreted with caution.

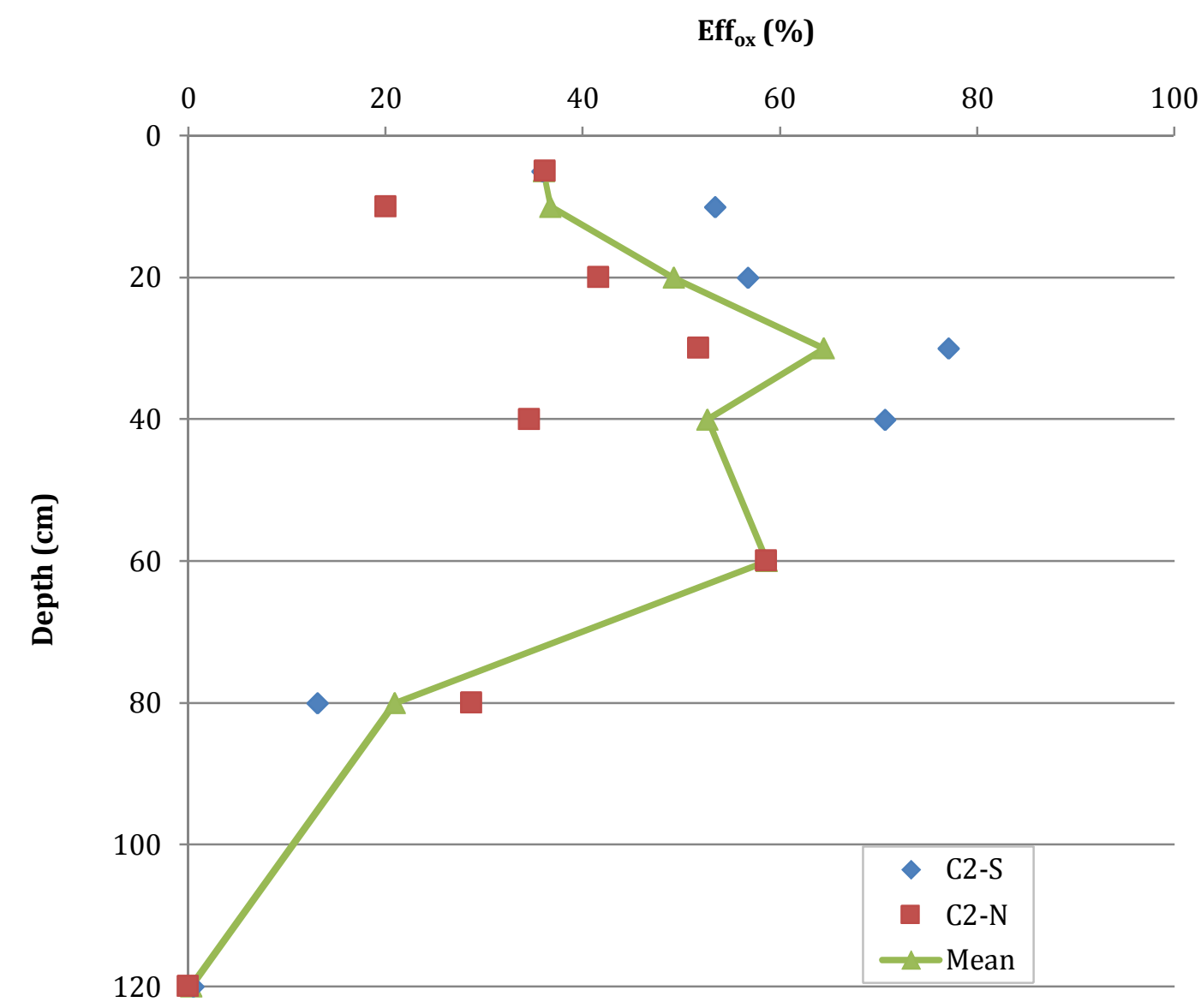

Figure 22 Average oxidation efficiency profiles at $C 2-S$ and $C 2-N$ and mean profile for both locations for the entire study period.

Average oxidation efficiency profiles for the entire study period are again presented in Figure 22, for $\mathrm{C} 2-\mathrm{N}, \mathrm{C} 2-\mathrm{S}$, including the mean oxidation efficiency profile for both 
locations. The figure shows the depth of maximum mean efficiency values for each location; $60 \mathrm{~cm}$ for $\mathrm{C} 2-\mathrm{N}(59 \%)$ and at $30 \mathrm{~cm}$ for $\mathrm{C} 2-\mathrm{S}(77 \%)$. All in all, based on the data obtained in this study, the maximum oxidation efficiency at cell 2 for the study period was attained near the middle of the top cover, between 30 and $60 \mathrm{~cm}$. The maximum mean efficiency at cell 2, calculated from data obtained at both locations throughout the study period, was $64 \%$ (at $30 \mathrm{~cm}$ depth), bearing in mind that the oxidation efficiency is neither an accurate nor constant value, and that this method is only intended to give an indication of the efficiency.

\subsection{Spatial and temporal variability}

\subsubsection{Spatial variation between $\mathrm{C} 2-\mathrm{N}$ and $\mathrm{C} 2-\mathrm{S}$}

Ideally, assuming homogeneous gas flow from the waste at cell 2 and a homogeneous top cover, gas concentration profiles at $\mathrm{C} 2-\mathrm{N}$ and $\mathrm{C} 2-\mathrm{S}$ should be near identical, since sampling time and meteorological conditions were the same. It is however well established that both waste body and soil cover are highly heterogeneous, resulting in high spatial and temporal variability of gas generation and gas flux. This is confirmed by the differences observed between $\mathrm{C} 2-\mathrm{N}$ and $\mathrm{C} 2-\mathrm{S}$, which are located on the same cell. Also, while most of the profiles at $\mathrm{C} 2-\mathrm{S}$ were similar, there was a much greater disparity between profiles obtained at $\mathrm{C} 2-\mathrm{N}$.

The results presented in the preceding chapters indicate a deeper air penetration and deeper oxidation horizon at $\mathrm{C} 2-\mathrm{N}$ than at $\mathrm{C} 2-\mathrm{S}$. The maximum methane oxidation efficiency along the profile was also obtained at a greater depth at $\mathrm{C} 2-\mathrm{N}$ than at $\mathrm{C} 2-\mathrm{S}$, but at a lower value. Observing gas concentration profiles in Figure 18 and in Figure 19, there is more consistency in results obtained at C2-S than at C2-N. Excluding December 2012, high Eff ox $_{\text {values or }}$ 91-97\%, were obtained at C2-S at 30 or $40 \mathrm{~cm}$ depth, while maximum Eff ox $_{\text {values ranged }}$ from $0 \%$ to $99 \%$ at $\mathrm{C} 2-\mathrm{N}$ at $60 \mathrm{~cm}$ depth. Aside from the differences between the two locations, there is also a much greater disparity of oxidation efficiencies at $\mathrm{C} 2-\mathrm{N}$ than at $\mathrm{C} 2$ $\mathrm{S}$. The difference between the two locations and disparity of results can be the result of physical differences in the waste body or the top cover, or a combination of the two.

As discussed in Chapter 3.2.1, the composition of waste landfilled at Fíflholt changed during the time cell 2 was being filled, between 2003 and 2006. C2-N is situated near the middle of the cell, while C2-S is closer to the southern end that was last landfilled. The waste body below $\mathrm{C} 2-\mathrm{N}$ is therefore slightly older than $\mathrm{C} 2-\mathrm{S}$, about 8-9 years old during the time of the present study vs 7-8 years old at C2-S. As Figure 7 in Chapter 3.2.1 shows, food and paper waste decreased during the period of landfilling while the amount of wood and industrial waste increased considerably. This is not including the daily cover material that would contribute to the biodegradable material in the waste body, as the landfill started using chopped wood as a daily and final cover in 2004. In 2005, there was a large increase in industrial waste, i.e. non-household waste that was categorized as "Mixed commercial waste from companies" and "Other waste from municipalities". These waste categories can be assumed to contain a high fraction of biodegradable material, although they are categorized as "industrial" for the IPCC model.

The difference in waste composition at the two locations could indicate a higher anaerobic landfill gas generation rate below $\mathrm{C} 2-\mathrm{S}$, since both locations appear to be in active phase with typical landfill gas concentrations, see Chapter 0 . A drop in oxidation efficiencies has been reported if the landfill gas flow rate exceeds the maximum oxidation rate of the soil (Chanton et al., 2011). The results of this study indicate, however, that there was good active 
oxidation activity at $\mathrm{C} 2-\mathrm{S}$ with high oxidation efficiencies, consistently better than at $\mathrm{C} 2-\mathrm{N}$, with the exception of December results when no oxidation was observed at both locations. It therefore appears that the maximum oxidation rate of the soil was not reached at C2-S, and although the gas flow beneath might be higher than at $\mathrm{C} 2-\mathrm{N}$, the difference in waste composition does not explain the difference observed between the two locations.

There is also the age difference between the two locations, as they were landfilled within 2 years of each other. Assuming that maximum gas generation is reached 5-7 years after depositing waste and that the waste composition was identical at the two locations, the gas generation would be lower at a given time during the time of study at $\mathrm{C} 2-\mathrm{N}$. With a lower gas load, the cover would have a better chance oxidizing the gas passing through it, leading to higher oxidation efficiencies. This is however not the case. Also, if maximum gas generation was not yet reached during time of sampling, and that the flow rate was higher at $\mathrm{C} 2-\mathrm{N}$ than at $\mathrm{C} 2-\mathrm{S}$, this still would not explain the high discrepancy observed between the two locations in August 2013. Neither gas composition nor age appears to explain differences measured between $\mathrm{C} 2-\mathrm{S}$ and $\mathrm{C} 2-\mathrm{N}$, although more data would be needed to verify this.

Another reason for the difference observed between the two locations lies in the physical properties and conditions of the top cover. At optimum soil moisture levels, oxidation activity is dependent on soil texture, specifically on pore size distribution. A higher share of pores increases the availability for gaseous transport. According to site technicians, the covers should be the same throughout the cell, i.e. same thickness and composition of wood chips and soil. The soil is however very heterogeneous in itself, with size particles ranging from large boulders to fine grains, and soil's air capacity is reduced with increased compaction. The top cover $\mathrm{C} 2-\mathrm{N}$ and $\mathrm{C} 2-\mathrm{S}$ has been subject to compaction to some extent due to operational traffic load, but the degree of compaction was not tested for this study, e.g. via cone test.

As discussed in Chapter 2.5.2, gas diffusion is highly dependent on the soil's water content. The fact that the $120 \mathrm{~cm}$ tube was filled with water at $\mathrm{C} 2-\mathrm{N}$ at every sampling date except for December 2012 indicates that the bottom of the top cover was typically saturated at that location, except during very dry periods such as encountered in December. At $120 \mathrm{~cm}$ depth at $\mathrm{C} 2-\mathrm{N}$, which is at the interface between the waste layer and top cover, the cover seems to have a high water retaining capacity. This might drive landfill gases to migrate via preferential pathways such as cracks in the cover or via lateral diffusion to areas adjacent to the cell, which could explain at $\mathrm{C} 2-\mathrm{N}$ the disparity in gas profile concentrations and oxidation efficiencies by depth and time, and generally lower oxidation efficiency values observed. This might also explain why in August 2013, zero efficiencies were observed at $\mathrm{C} 2-\mathrm{N}$ against high efficiencies at C2-S. The variation between $\mathrm{C} 2-\mathrm{S}$ and $\mathrm{C} 2-\mathrm{N}$ is discussed in more detail in the following chapters with regards to atmospheric pressure, atmospheric temperature, soil temperature and precipitation.

\subsubsection{Atmospheric Pressure}

The gas profile method assumes steady state gas flow conditions during time of measurement. A number of studies have shown the relationship between pressure change and the landfill gas release through the top cover (e.g. Kjeldsen, 1996, Gebert \& Gröngröft, 2006). When the atmospheric pressure drops rapidly, the formed pressure gradient can lead 
to advective gas transport out of the waste layer, which can result in higher emissions and possibly lower efficiencies.
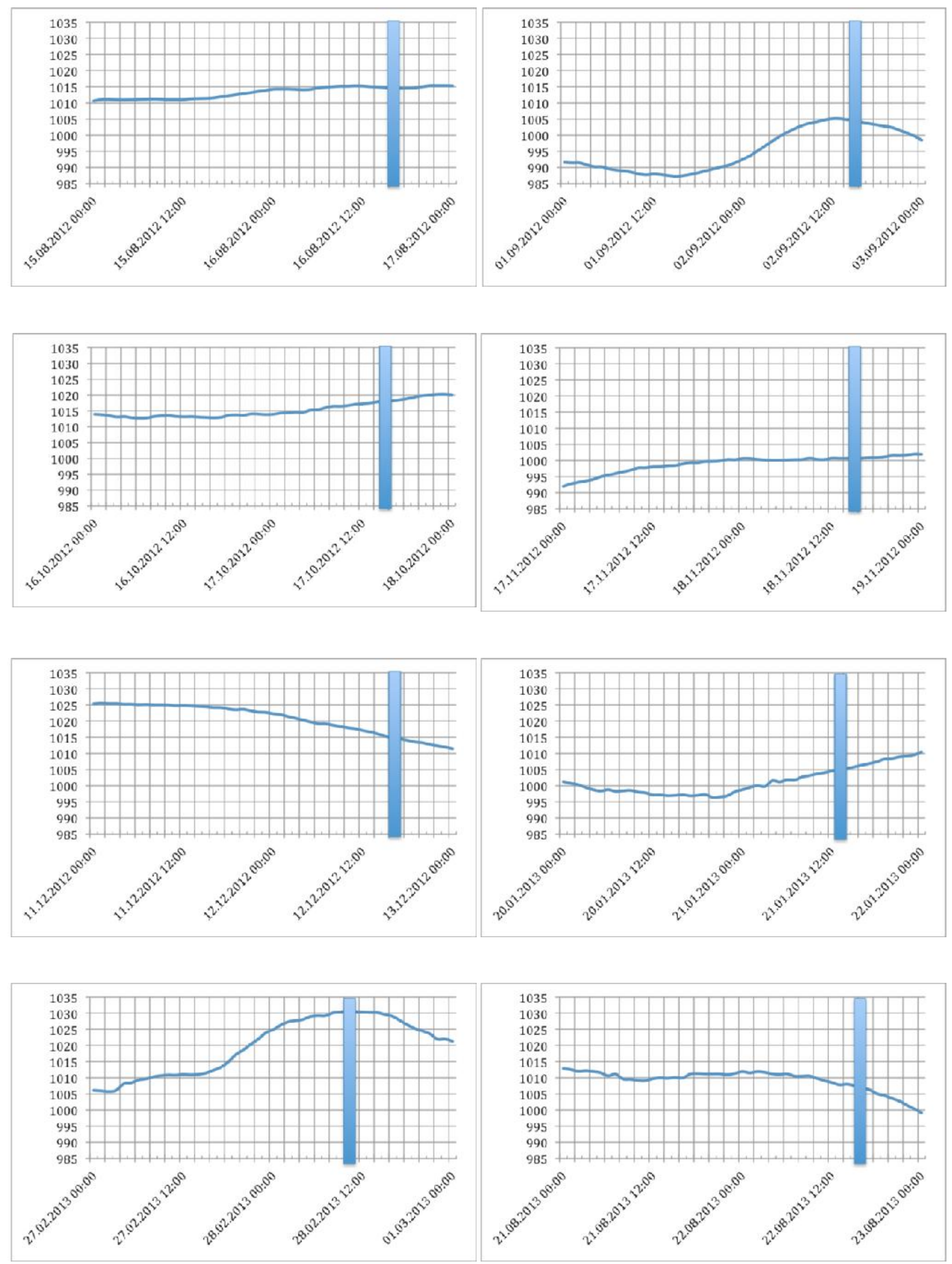

Figure 23 48-hour air pressure (hPa) development during each sampling date of the study, August 2012 August 2013. The blue vertical lines denote the time of sampling. 
Over the study period, point air pressures between 1001 and $1031 \mathrm{hPa}$ were recorded. Figure 23 shows the air pressure development of 48 hours during which samples were taken. In most cases, atmospheric pressure did not undergo big changes during time of sampling.

Slight pressure drops were observed during sampling in December 2012 and August 2013, where over the course of 12 hours the pressure dropped by about $5 \mathrm{hPa}$, or the equivalent of $5 \mathrm{kgf} / \mathrm{mm}^{2}$ or a $5 \mathrm{~cm}$ water column, the equivalent of a $0.4 \mathrm{mbar} / \mathrm{h}$ pressure drop. Zero efficiency values were obtained on those dates, in December at both locations and in August 2013 at C2-N, when high concentrations of methane were measured at the surface. In August 2013 , however, the oxidation efficiency was about $97 \%$ at C2-S, meaning that the cover at that location was capable of oxidizing almost all of the $\mathrm{CH}_{4}$ when it was incapable of oxidation at $\mathrm{C} 2-\mathrm{N}$. This indicates that atmospheric pressure was not the most important factor at play in the oxidation process in August 2013, but rather other factors such as the water content of the material. There was a slight rise in atmospheric pressure during sampling in January 2013, or an approx. $5 \mathrm{hPa}$ rise over the course of 12 hours. A rise in pressure can lead to lower flux rates through the cover, increasing its ability to oxidize the gas passing through it. Conformingly, on this date, high oxidation efficiencies were obtained.

\subsubsection{Soil temperature and atmospheric temperature}

On five sampling dates, soil profile temperatures were measured to corroborate with gas concentrations, see Figure 24. Soil temperatures were measured during the winter months of November to February, and also in August 2013. During the winter months, the soil temperature increased slightly with depth or by approx. $0.3-0.5^{\circ} \mathrm{C}$ per $10 \mathrm{~cm}$, reaching $<3^{\circ} \mathrm{C}$ at about $1 \mathrm{~m}$ depth. This is observed both when high oxidation efficiency values were obtained in November, January and February, and when very poor efficiency values were obtained in December. In August 2013, when the ambient temperature was higher, typical of Icelandic summers, the soil temperature decreased slightly with depth in the first $20 \mathrm{~cm}$, after which the temperature was relatively constant.

Soil temperatures were similar at locations $\mathrm{C} 2-\mathrm{N}$ and $\mathrm{C} 2-\mathrm{S}$, and were generally quite low at the bottom of the top cover $\left(2-12^{\circ} \mathrm{C}\right)$ given that high oxidation efficiencies were generally observed. It is also of note that relatively high oxidation efficiencies were equally obtained at higher $\left(\sim 12^{\circ} \mathrm{C}\right)$ and at lower atmospheric temperatures $\left(\sim 0-2^{\circ} \mathrm{C}\right)$. Temperatures are much higher at similar depths in other climates, where high oxidation has been reported (Scheutz et al., 2009), or around $25-35^{\circ} \mathrm{C}$, although oxidation has also been reported in colder areas at temperatures down to $2^{\circ} \mathrm{C}$ (Christophersen et al., 2000) and $1{ }^{\circ} \mathrm{C}$ (Einola et al., 2007).

Soil temperatures are being monitored continuously for an ongoing study on gas emissions from a wetland restoration area in Lundarreykjadalur, West Iceland, approx. $60 \mathrm{~km}$ southeast of Fíflholt. Similar to Fíflholt, the soil at Lundarreykjadalur is made up of Histic Andosol and Brown Andosol, but probably contains slightly less organic matter due to its elevation and stronger winds (Arnalds \& Óskarsson, 2009). Soil temperatures at $40 \mathrm{~cm}$ depth range from approx. $0.5^{\circ} \mathrm{C}$ during winter months (December - February) to approx. $12^{\circ} \mathrm{C}$ during summer months (July - August), and from approx. $0^{\circ} \mathrm{C}$ to $14^{\circ} \mathrm{C}$ for the same months at 10 $\mathrm{cm}$ depth (Ólafsdóttir, 2013, unpublished data). These measurements, i.e. relatively low soil temperatures, conform well with the sparse measurements at Fíflholt. 


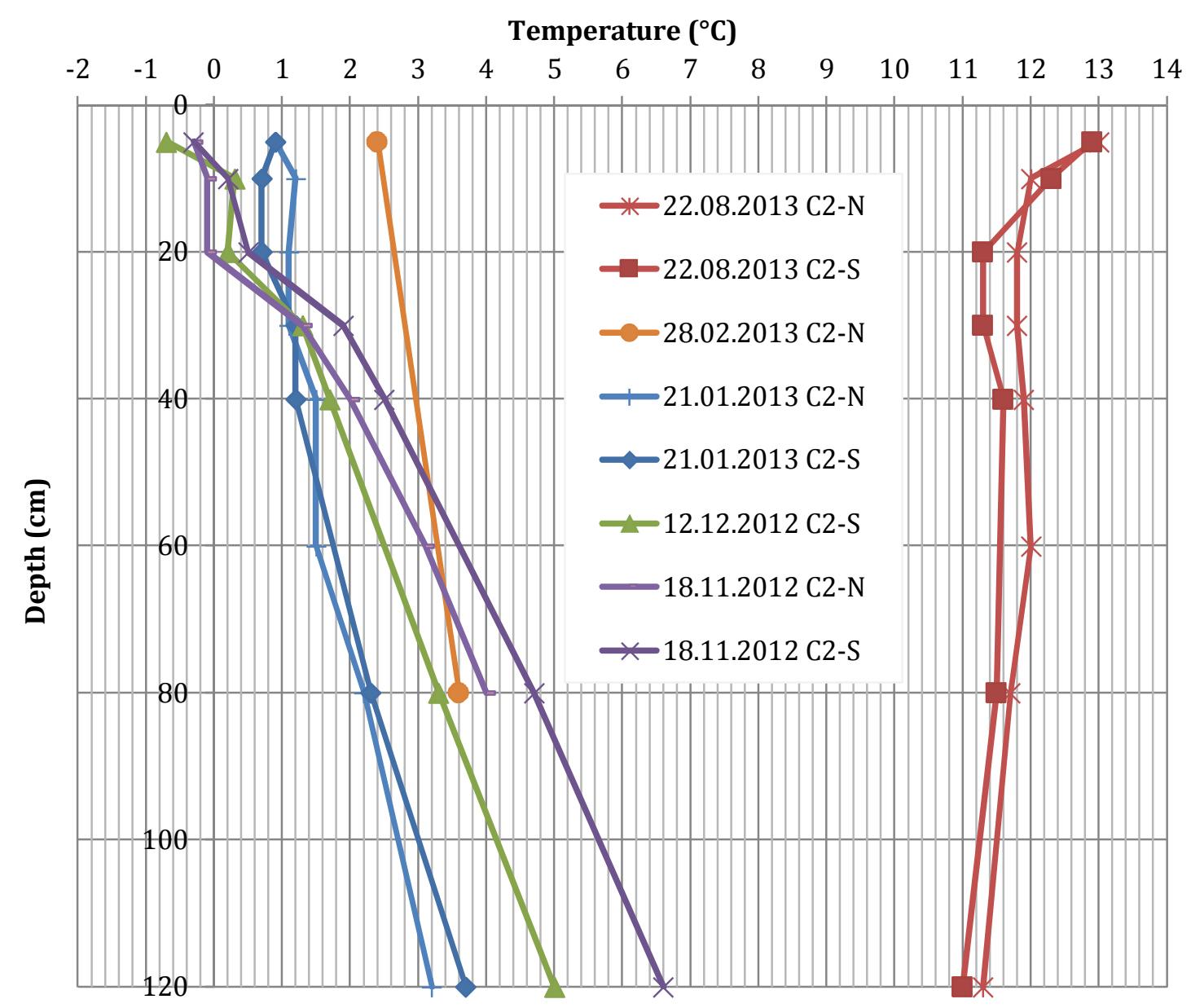

Figure 24 Soil temperature profiles, measured at C2-N and C2-S at the Fiflholt landfill during the study period.

Given the high oxidation efficiencies obtained during the winter months, with the exception of December, and soil temperatures $<6^{\circ} \mathrm{C}$ at $1 \mathrm{~m} \mathrm{depth}$, it is probable that oxidation can take place throughout the year, even during low temperatures in winter. High efficiencies were also obtained when frost was still in the ground; such as encountered in November 2012, see Figure 26 and Figure 27. Figure 25 and Figure 26 show the relationship between calculated oxidation efficiencies and atmospheric and soil temperatures for both sampling locations, $\mathrm{C} 2-\mathrm{S}$ and $\mathrm{C} 2-\mathrm{N}$. No correlation is apparent between temperature and oxidation efficiency, i.e. higher oxidation efficiency was neither observed with increasing ambient temperature, nor increasing temperature within the soil cover (generally with depth), suggesting that temperature is not a controlling factor in the oxidation process in this study. 


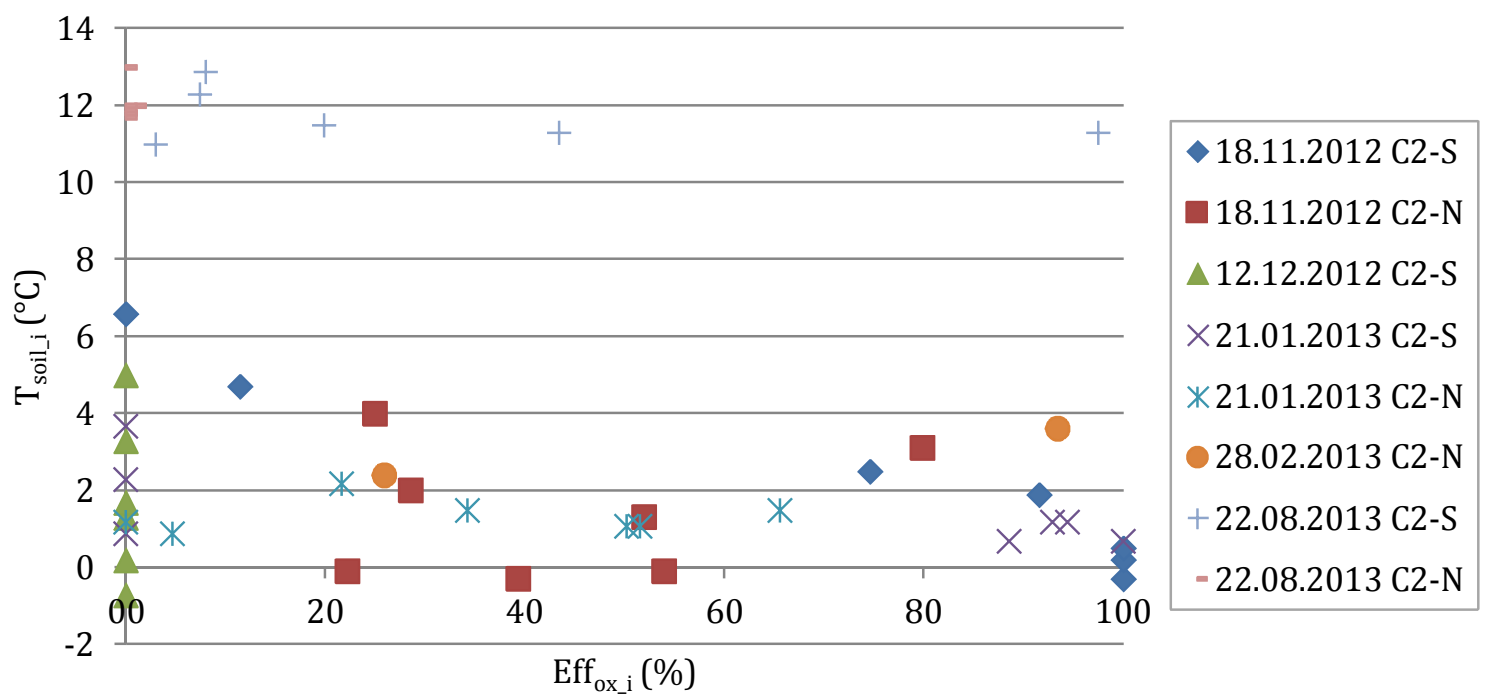

Figure 25 Soil temperature at depth $i, T_{\text {soil } i}\left({ }^{\circ} \mathrm{C}\right)$, vs oxidation efficiency at depth $i$, Eff ox $i_{i}(\%)$, for both measurement locations $C 2-S$ and $C 2-N$ during the study period.

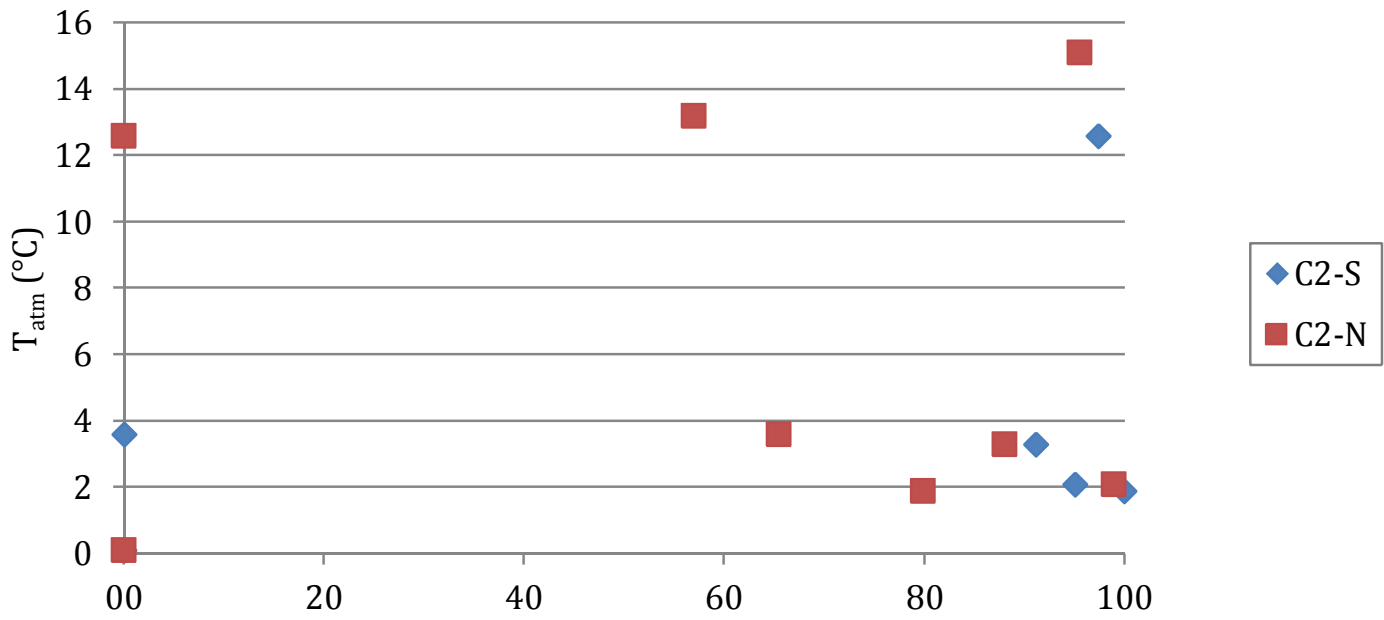

$\operatorname{Max} \operatorname{Eff}_{\mathrm{ox}}(\%)$

Figure 26 Atmospheric temperature vs maximum oxidation efficiencies, max Eff ox, at C2-S and C2-N during the study period. 


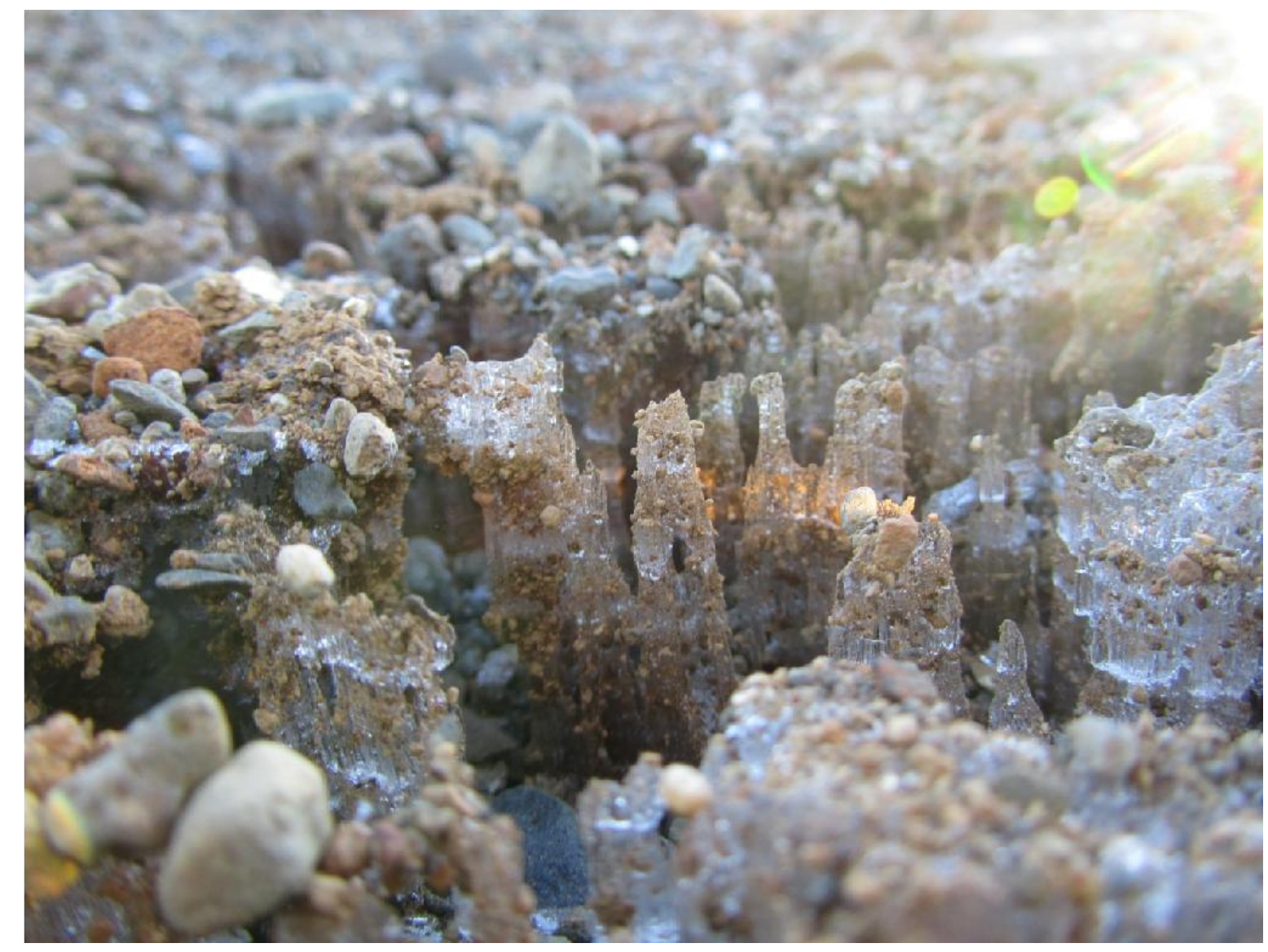

Figure 27 A photo of the ground on top of Cell 2 at the Fiflholt landfill, next to C2-N, taken during sampling on November 18, 2012. The temperature was $1.9^{\circ} \mathrm{C}$ and the ground was still frozen. Photo: AK.

\subsubsection{Accumulated precipitation and soil water content}

Precipitation data monitored during the study can give us an idea of the soil saturation condition. Accumulated precipitation is given in $24 \mathrm{hrs}, 48 \mathrm{hrs}$ and 7 days prior to sampling. Precipitation data is presented in Table 1 in Chapter 3.2.2, and its relationship with maximum oxidation efficiency, max Eff $\mathrm{ox}_{\mathrm{ox}}$ is presented in Figure 28. Given the porous nature of the cover soil, it probably drains water efficiently over the course of a few days, thus the importance of both $24 \mathrm{hr}$ and $48 \mathrm{hr}$ accumulation data.

As seen in Table 1, conditions were dry on December 12, 2012, when only $4.5 \mathrm{~mm}$ accumulated in 7 days and $0 \mathrm{~mm} 48$ hours prior to sampling. This was also the only time during the study period that the $120 \mathrm{~cm}$ tube at $\mathrm{C} 2-\mathrm{N}$ was not filled with water. The highest profile gas concentrations and zero efficiency values obtained during this study were also obtained on this date, indicating that the lack of moisture in the soil, possibly coupled with a low temperature of $0.1^{\circ} \mathrm{C}$, may have brought microbial activity to a standstill. Gas flow rates might also have been slightly higher on this date since there was a slight pressure drop observed.

As mentioned in Chapter 4.4.1, the bottom of the top cover at $\mathrm{C} 2-\mathrm{N}$ appears to have been generally saturated, except in December 2012 when conditions were very dry. There is the possibility that the cover material at the base of $\mathrm{C} 2-\mathrm{N}$ is by chance finer than in surrounding areas. This, coupled with the layer of decomposing chopped wood as a final cover material, 
might render the base of the top cover prone to saturation, particularly after periods of high precipitation. While this may be beneficial to maintain moisture for the microbiota, this might in turn alter upward gas transport and cause gas to migrate via preferential pathways or via less saturated areas, possibly decreasing the net $\mathrm{CH}_{4}$ oxidation and increasing emissions. The base of the top cover at $\mathrm{C} 2-\mathrm{N}$ might in fact be functioning as a capillary barrier against the coarser waste layer beneath, not only limiting gas flow but also impeding water infiltration into the waste mass.

15-17 mm of precipitation accumulated 7 days prior to sampling, none within $48 \mathrm{hrs}$, in October, November and January. High oxidation efficiencies were observed on those sample dates, see Figure 28. High oxidation efficiency was also observed in August 2012, when 7day accum. prec. was $89 \mathrm{~mm}$, none within $48 \mathrm{hrs}$. The water content of the soil was probably higher in September 2012, February and August 2013, when $13.7 \mathrm{~mm}, 8.3 \mathrm{~mm}$ and $6.9 \mathrm{~mm}$ accumulated 48 hours prior to sampling, respectively. Efficiency values were medium in September (at C2-N) but relatively high in February (both locations). In August 2013, oxidation efficiency was zero at $\mathrm{C} 2-\mathrm{N}$ but high at $\mathrm{C} 2-\mathrm{S}$. Based on the sparse data obtained in this study and presented in Figure 28, no correlation could be made between precipitation data and oxidation efficiency. Periods of drought, exhibited in little accumulated precipitation 7 days prior to sampling, might however correspond with low oxidation efficiencies, although much more data is needed to establish a relationship.

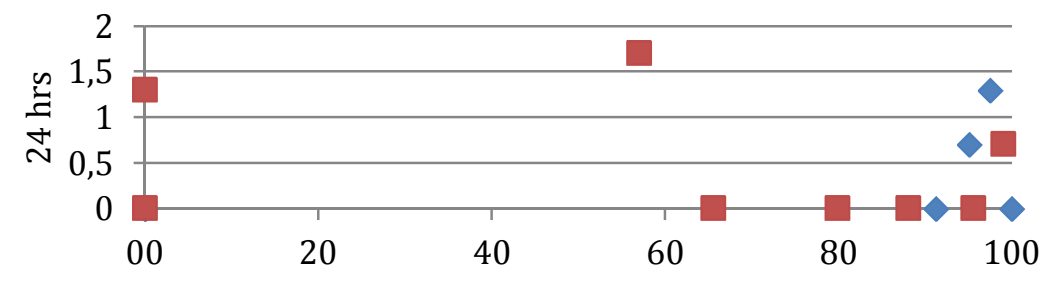

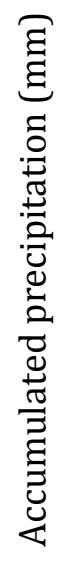
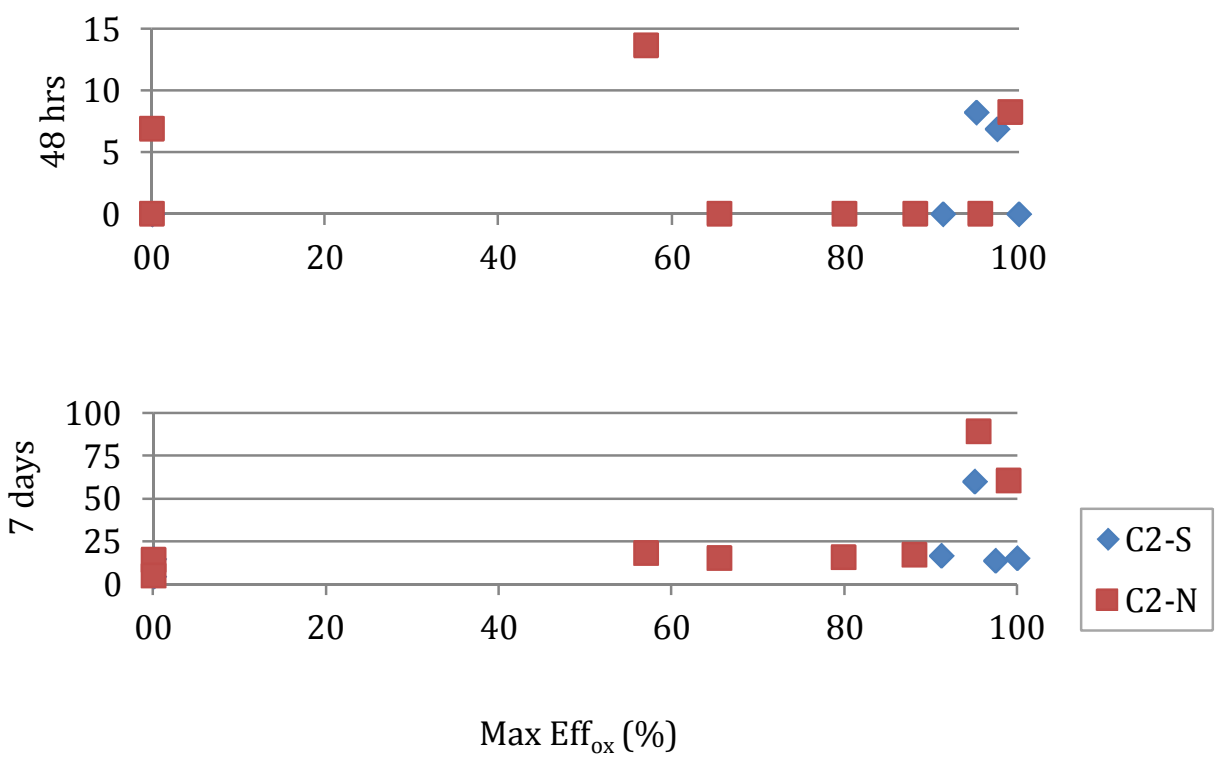

Figure 28 Accumulated precipitation (24 hrs, 48 hrs, 7 days) (mm) vs maximum oxidation efficiency (max Effox) (\%) for C2-S and C2- $N$ during the study period. 


\section{Discussion}

\subsection{Methane Oxidation at Fíflholt and Suitability of Passive Methane Oxidation Biosystems}

In the case of larger landfills such as Álfsnes, receiving about 100,000 tons of waste per year, effective gas collection systems are the most effective means of reducing emissions (e.g. Börjesson et al., 2007). Conventional gas recovery efficiency however rarely exceeds $50-70 \%$ of the gas generated, and even at sites with good recovery rates, high amounts of landfill gas can still escape. Indeed, preliminary flux measurements performed at the Álfsnes landfill in Reykjavík in 2012 revealed significant fluxes of methane from the surface, see Appendix C.

At lower flow rates, methanotrophic bacteria can consume a larger portion of the methane delivered. A passive methane oxidizing systems is therefore a viable management approach for the treatment of fugitive emissions at landfills with recovery systems, or for landfills with a low methane generation rate per area and for cells that have limited height. Aside from the three largest landfills in Iceland currently in operation (Álfsnes, Stekkjarvík, Fíflholt), all other landfills in Iceland receive $<5,000$ tons of waste per year. According to Scharff et al (2011), waste degradation and thus methane generation rate in small Icelandic landfills is likely lower than in a moderate European climate.

In shallow landfills $(<8 \mathrm{~m}$ depth), which are common in Iceland, the installation of gas extraction systems is technically either very difficult or near impossible (Scharff et al., 2011), whether wells are horizontal or vertical. Such a system would also very likely take in atmospheric air through the extraction system, highly reducing the recovery efficiency, as all Icelandic landfills to date are unlined.

The mean maximum oxidation efficiency of this study was $59 \%$ at $\mathrm{C} 2-\mathrm{N}(60 \mathrm{~cm})$ and $77 \%$ at $\mathrm{C} 2-\mathrm{S}(30 \mathrm{~cm})$, with a mean value of $64 \%$ for both locations. In a recent review of 15 studies conducted over an annual cycle, Chanton et al. (2009) found that the oxidation efficiency, ranging from 11 to $89 \%$, had a mean value of $35 \pm 6 \%$. Five of these studies were conducted in northern Europe $\left(50-55^{\circ} \mathrm{N}\right)$ and exhibited an average of $54 \pm 14 \%$. The results of this study, based on a limited database, conform well to this review.

Given the evidence provided by this study, the top cover at Fiflholt can be considered as a passive biosystem, oxidizing a significant fraction of the landfill gas passing through it. The top cover was however not designed with this purpose in mind. It was installed to comply with the operational permit, requiring a soil cover of minimum thickness $1 \mathrm{~m}$. The soil's physical parameters, however, as discussed previously in this study, renders it very suitable as an oxidizing top cover. Considerations can be made nevertheless regarding the base of the cover, as the layer of decomposing chopped wood may be prone to saturation and may alter upward gas transport.

Appropriate measures have to be taken in the design of a methane oxidation biosystem. Conditions for methane oxidation can be enhanced choosing appropriate soils for a GDL and MOL layer, see Chapter 2.5.3, and following a list of criteria such as grain size distribution, layer thickness and organic matter content. Vegetation has also been recommended to 
prevent erosion and maintain moisture of the soil, although the overall role of vegetation is still subject of research. Methane oxidizing covers cannot be designed, however, without a statement on required efficiency. The feasibility of a methane oxidizing system increases if a requirement is set for yearly efficiency, i.e. annual mean efficiency rather than e.g. daily or monthly efficiency, since oxidizing covers are typically less efficient during the cold winter.

\subsection{Measured Gas Fluxes on Selected Dates}

Gas fluxes were measured on sampling dates during the winter months, from October 2012 to February 2013. Fluxes were measured after a simple visual and olfactory inspection in order to identify hot spots, if any. No FID scan was carried out, which would have been preferable, as no such equipment was available. Table 11 summarizes flux ranges measured in proximity to $\mathrm{C} 2-\mathrm{N}$ and $\mathrm{C} 2-\mathrm{S}$, i.e. within $10 \mathrm{~m}$ distance of sampling tubes (Meyvantsdóttir, 2013, unpublished data).

Table 11 Gas flux ranges $\left[\mathrm{g} / \mathrm{m}^{2} / \mathrm{d}\right]$ measured during the study period in proximity to $C 2-\mathrm{N}$ and $\mathrm{C2}-\mathrm{S}$, i.e. within $10 \mathrm{~m}$ distance of sampling tubes. $n=$ number of measurements (Meyvantsdóttir, 2013, unpublished data).

\begin{tabular}{|c|c|c|c|c|c|c|}
\hline \multirow{2}{*}{ Date } & \multicolumn{3}{|c|}{$\mathrm{C} 2-\mathrm{N}$} & \multicolumn{3}{c|}{$2-\mathrm{S}$} \\
\cline { 2 - 7 } & $\begin{array}{c}\mathrm{CH}_{4} \\
{\left[\mathrm{~g} / \mathrm{m}^{2} / \mathrm{d}\right]}\end{array}$ & $\begin{array}{c}\mathrm{CO}_{2} \\
{\left[\mathrm{~g} / \mathrm{m}^{2} / \mathrm{d}\right]}\end{array}$ & $\mathrm{n}$ & $\begin{array}{c}\mathrm{CH}_{4} \\
{\left[\mathrm{~g} / \mathrm{m}^{2} / \mathrm{d}\right]}\end{array}$ & $\begin{array}{c}\mathrm{CO}_{2} \\
{\left[\mathrm{~g} / \mathrm{m}^{2} / \mathrm{d}\right]}\end{array}$ & $\mathrm{n}$ \\
\hline 17.10 .2012 & {$[-0.6-5.4]$} & {$[0-35.5]$} & 5 & {$[0-0.1]$} & {$[0-0.7]$} & 4 \\
\hline 18.11 .2012 & {$[0]$} & {$[-0.2-0.1]$} & 4 & {$[0.1]$} & {$[0-0.4]$} & 2 \\
\hline 12.12 .2012 & {$[0-1.0]$} & {$[0-3.6]$} & 3 & - & - & 0 \\
\hline 21.01 .2013 & {$[0-4.5]$} & {$[0.0-23.2]$} & 18 & {$[0-0.1]$} & {$[0-0.6]$} & 7 \\
\hline 28.02 .2013 & {$[0-0.4]$} & {$[0.0-6.2]$} & 17 & - & - & 0 \\
\hline
\end{tabular}

As Table 11 shows, very low fluxes were measured during the five sampling dates, i.e. in the range of [-0.6 - 5.4] $\mathrm{g} \mathrm{CH}_{4} / \mathrm{m}^{2} / \mathrm{d}$ and $[-0.2-35.5] \mathrm{g} \mathrm{CO}_{2} / \mathrm{m}^{2} / \mathrm{d}$. Given the very limited number of measurements and the small area covered during each of these chamber flux measurements, these values can at best give an idea of gas emissions from the top cover in proximity to sampling locations. Fluxes were also measured on a few other locations on cell 2 , between $\mathrm{C} 2-\mathrm{N}$ and $\mathrm{C} 2-\mathrm{S}$ and on the outskirts of the cell, but measured values fall within ranges in Table 11.

When high concentrations of $\mathrm{CH}_{4}$ were measured in shallow gas profiles in December 2012 hardly any fluxes were detected, contrary to what could be expected from zero-oxidation efficiency calculations, dry conditions and pressure drop during this date. Because only few fluxes were measured that day in proximity to the sampling locations due to technical issues, it is very likely that high emission areas were missed, where higher fluxes would have been detected.

Landfill gas will escape through all openings and cracks, i.e. preferential pathways, and has been reported to escape through leachate collection wells (e.g. Scheutz et al., 2011a). Monitoring wells for groundwater level are situated at the periphery of the landfill cells. The closest one to $\mathrm{C} 2-\mathrm{N}$ is situated about $100 \mathrm{~m}$ to the north, outside cell no. 1. Leachate, collected by drain pipes at the bottom of the cell, flows to wells at the south of each cell, 
then to a collective well and settlement pond before it is drained through a soil filter. Upon inspection on February 12 $2^{\text {th }}, 2012$, a sulphuric odour was in the collective well next to the pond and soil filter (EFLA, 2012), indicating landfill gas escape. Individual leachate collection wells below each cell were not inspected during the period of the present study, but there is the possibility that a fraction of the landfill gas escapes through the leachate collection system.

\subsection{Limitations and Suitability of the Gas Profile Method}

The gas profile method, which is the basis of this study and detailed in chapter 3.4.1, is subject to some limitations, based on the assumptions made for its application. Assumptions of particular concern regard microbial soil respiration and steady state, while assumptions on the nominal reaction, equilibrium of gas and liquid phase of $\mathrm{CO}_{2}$ and $\mathrm{CO}_{2}$ precipitation are assumed to be valid.

It is assumed that there is no net transfer of carbon into the microbial biomass. This can be assumed to be valid since the top cover consists of local soil from cell excavations, and the cover had been in place for 7-9 years at the time of this study. $\mathrm{CO}_{2}$ can also be released, however as a result of aerobic microbial decomposition of organic matter in the soil to obtain energy, i.e. microbial respiration. The gas profile method assumes that this respiration is negligible compared to $\mathrm{CO}_{2}$ produced due to $\mathrm{CH}_{4}$ oxidation. In soils with little or no organic matter content, this assumption is respected.

In the case of Fiflholt, the organic matter content of the cover soil is $7 \%$ according to a LOItest, see Chapter 3.3.7, which is why a soil respiration test would be desirable to confirm the ratio of soil respiration. In a batch experiment using soil with total organic carbon (TOC) $4.9 \%-7.5 \%, \mathrm{CO}_{2}$ respiration accounted for $1.2-1.9 \%$ of the observed $\mathrm{CO}_{2}$ production from $\mathrm{CH}_{4}$ oxidation (Gebert et al., 2011). In the same study, when assessing the validity of the gas profile method with mass balance calculations, the oxidation efficiency was only slightly overestimated using a soil with $6 \%$ organic matter, although the overestimation was not as important at high efficiencies. A greater overestimation was obtained using a soil with $18 \%$ organic matter. Respiration can therefore account for a certain error in the oxidation efficiency calculations for Fíflholt, although we can assume that it is not major.

The gas profile method assumes steady state conditions, which is rarely encountered in the field as gas flow rates vary continuously with precipitation and changes in atmospheric pressure. As discussed in Chapter 4.4, there was some disparity in pressure and accumulated precipitation data, that can result in under- or overestimations of oxidation efficiencies. Long-term field measurements covering all seasons are therefore recommended, as different climatic conditions are thus accounted for and under- and overestimation even each other out, giving a better indication of the mean oxidation efficiency.

Steady state gas flows, or stable weather conditions in terms of pressure and precipitation, was presumably not always the case during this study. At Fiflholt, measurements were carried out on eight occasions stretched over a period of one year from August 2012 - August 2013 (7 consecutive months +1 month); including two summer months (August 2012 and August 2013), two fall months (September and October 2012), and three winter months (November, December 2012 and January 2013). No measurements were carried out in spring 
(April/May) or first months of summer (June/July). Although these sampling dates covered the range of typical atmospheric temperatures observed throughout the year in Iceland (0$15^{\circ} \mathrm{C}$ ), more frequent measurements would have improved the net results, e.g. weekly measurements or twice a month. A short-term measurement campaign covering daily fluctuations (e.g. sampling every 2-3 hours) would also have been helpful.

As discussed in the following chapter, gas concentrations were only measured at two locations on top of cell 2, which means that high or low emission areas could easily have been missed. The two locations in question are not necessarily representative of the whole cell, even less so of the whole landfill. In order to account for spatial variability, sampling locations would have to be many and equally distributed. Using only the gas profile method, this would be tedious work. Ideally, the gas profile method should be coupled with another wide-spaced measurement technique covering spatial variation of emissions, see Chapter 5.4. Complementary low-cost analyses can also be performed to better document the area and to prepare location of sampling probes, e.g. FID screening. Despite these limitations, the results of this study give an idea of the range of oxidation efficiencies that can be expected.

The gas profile method is suitable for application where assumptions are respected or can be almost validated. This applies in settings in which the $\mathrm{CO}_{2}$ concentration is not significantly influenced by respiration, i.e. when quantities of $\mathrm{CO}_{2}$ generated from respiration are small compared to generation from $\mathrm{CH}_{4}$ oxidation, and where the assumption of steady state is respected. It is therefore neither suitable for landfills with high organic matter content in the top cover, nor for point or short term measurement campaigns, not taking into account temporal variability.

Mitigation of $\mathrm{CH}_{4}$ emissions is now required by EU and Icelandic legislation. If full-scale passive methane oxidation biosystems are to be implemented, reliable and readily available emission measurement techniques are required to ensure proper efficiency of the system. State-of-the-art equipment and measurement techniques are currently not considered accurate and reliable enough to use to comply with EU regulations, but with more research this might improve in the near future.

If potential errors can be accounted for or neglected (steady state and respiration), the gas profile method is both very cost efficient and technically feasible to estimate the $\mathrm{CH}_{4}$ oxidation efficiency. It can thus prove meaningful for green accounting or national inventory reports, replacing the default 0 or $10 \%$ value by a documented and more reasonable value, see discussion below.

\subsection{Choice of IPCC Methane Oxidation Factor to Estimate Methane Emissions}

Methane emissions from landfills are essentially a product of landfill gas generation, recovery and microbial $\mathrm{CH}_{4}$ consumption, both depending on a large number of soil specific and meteorological factors. Credible national estimates of carbon emissions from landfills are therefore not easy to develop. Iceland is a participant in the United Nations Framework Convention on Climate Change (UNFCCC) since 1994 and as such is required to periodically compile greenhouse gas inventories and present a yearly National Inventory Report, including a quantification of estimated emissions. Estimation methods are 
harmonized with the IPCC Guidelines for National Greenhouse Gas Inventories, using the IPCC model, which is a free open-access model to estimate methane emissions.

In the National Inventory Report (NIR) on greenhouse gas emissions in Iceland from 1990 to 2010, emissions from landfills are estimated using the IPCC Guidelines. Estimates are in theory inclusive of landfill gas recovery and oxidation. Waste recovery is only a reality at the Álfsnes landfill in the capital area and has been documented since it began in 1997. The default IPCC oxidation factor of 0 was used in the NIR, which is recommended for developing countries (IPCC, 2006). A default oxidation value of $10 \%$ is however recommended in the IPCC Guidelines for industrial countries with well-managed landfills.

It is an ongoing subject of debate whether the $10 \%$ value is reasonable for landfills exhibiting much higher efficiencies through research. Although high oxidation efficiencies are reported, it is also important to remain on the conservative side, since it is generally believed that only a fraction of the $\mathrm{CH}_{4}$ generated is believed to diffuse through the top cover, while much of the gas will escape through cracks or via lateral dispersion without being oxidised. This brings us back to the quality of measurements performed to assess the oxidation. If high spatial variability is to be taken into account, measurements must be wide enough, preferably including high emission areas or hot spots. Measurements should also be indicative of annual average emissions, i.e. should cover seasonal variation.

According to the IPCC guidelines, if a higher value than $10 \%$ is to be used, it should be clearly documented, referenced and supported by data relevant to national circumstances. In a recent research study in Sweden, closed landfills had e.g. a higher fraction of oxidized methane than active landfills, leading to the recommendation that IPCC default values for methane oxidation in managed landfills, remaining on the conservative side, could be set to $10 \%$ for active sites and $20 \%$ for closed sites (Börjesson et al., 2007). Higher values are however rarely applied (IPCC, 2006).

Although the results of this study are far from conclusive, there is evidence that a large fraction of the gas passing through the cover at the Fiflholt landfill throughout the year is being oxidized. The results exhibit high disparity; with oxidation efficiencies of the cover at cell 2 ranging from 0 to $100 \%$. Based on the limited data obtained throughout the entire study period and assuming that only a small fraction of the gas escapes through cracks or vents, the mean maximum efficiency for cell 2 is about $60 \%$, typically attained near the middle of the $1.0-1.2 \mathrm{~m}$ deep cover, or at $30-60 \mathrm{~cm}$ depth.

As observed by Chanton et al. (2011), the the oxidation efficiency should however not be considered as a constant value, but rather a changing quantity that is a function of cover type, climatic conditions and $\mathrm{CH}_{4}$ loading to the bottom of the cover. It is furthermore difficult to assess the extent of gas flux bypassing the cover via cracks or preferential pathways. Measurements for this study were only carried out at two small locations on top of cell 2, and did not take into account possible high emission areas on the cell that may have been missed or a possible gas escape through the leachate collection system. Only larger scale measurement techniques such as meteorological methods or plume measurements can take high emission areas such as this into account. To date, there is however no consensus on which techniques are best fit to adequately and reliably assess methane oxidation from landfills. 
Finally, it must be taken into account that the IPCC guidance was only considered sufficiently accurate for the emissions estimation of an entire nation and never intended to be applied to individual landfills (Scharff and Jacobs, 2006), as low and high emission landfills would balance each other out. It can therefore be presumed that first-order degradation models are not sufficiently accurate for the estimation of individual landfill methane emissions. Parameters and assumptions are set conservatively, meaning that the landfill generation is most likely overestimated through modelling.

\subsection{New Requirements and IPCC Modelling at Fíflholt}

In compliance with the EU landfill directive, implemented in Iceland as Act 55/2003 and regulation no. 738/2003, landfills in Iceland are now required to collect landfill gas for utilization or flaring. This was however put forward without further conditions or technical guidance while it was realised that the majority of Icelandic landfills would not be able to comply with the requirements. At the demand of the Ministry of Environment, The Iceland Environmental Agency developed guidelines on when the collection of landfill gas should be required (EAI, 2012b). The guidelines are based on whether landfills accepting biodegradable waste (TOC $\geq 6 \%$ ) are large enough ( $\geq 50,000$ tons during operation) for it to be technically feasible to collect gas.

To aid landfill operators to determine gas recovery feasibility, the Icelandic EA made a localized copy of the 2006 IPCC model, fixing default parameters for Icelandic conditions (EAI, 2012). Landfill operators are to use this model to calculate whether gas generated at the entire landfill exceeds $0.16 \mathrm{Gg} /$ year for seven years or more, in which case the installation of a gas collection system is required. Using the model, it is by default assumed that no oxidation takes place and that emission rates equal generation rates. However, in agreement with the EA, results of the model can be calibrated using emissions measurements based on standardized methods.

Using waste inventories of waste types and quantities in Fiflholt's green accounting, the IPCC model was used to assess the gas generation of cell 2. Based on prior measurements, see Chapter 3.3.4, and measurements done for this study, see Chapter 0, the MCF factor was set as 1 (see definition in Chapter 2.6.1). Based on the inventories, waste was entered into the model according to the 9 waste categories of the IPCC model, see Chapter 2.6.1. The waste category "Municipal solid waste" of the inventory was recategorized into the following IPCC categories according to Icelandic EA guidelines, which is based on SORPA's annual report on waste composition (see Appendix B);

$\begin{array}{ll}\text { - } \text { Food 27\%, } & \text { - Textile 3\%, } \\ \text { - } \text { Garden 1\%, } & \text { - Nappies } 9 \%, \\ \text { - } \quad \text { Paper } 27 \%, & \text { - Inert } 32 \% \\ \text { - } \quad \text { Wood } 1 \%, & \end{array}$

Mixed industrial waste containing biodegradable waste was classified as Industrial and mixed industrial waste containing no biodegradable waste was classified as Inert. Waste input data and methane emission output was given in gigagrammes per year $(\mathrm{Gg} / \mathrm{y})$, the equivalent of 1000 tons per year. 
Methane emissions were assessed for Fíflholt, for cell 2 (filled 2003-2006) and cells 1-3 together (filled 1999-2012), based on green accounting waste inventories and using the current $0 \%$ oxidation value and a $50 \%$ oxidation value, see Figure 29 . Fíflholt only started doing green accounting in 2004, so waste inventories for 2003 are estimated using total waste numbers for 2003 and the same waste composition as in 2004 . The gas generation $(0 \%$ oxidation) at cell 2 does not reach or exceed the reference value $0.16 \mathrm{Gg} / \mathrm{y}$, but does however exceed it for cells 1-3 put together. If an arbitrary methane oxidation factor of $50 \%$ is assumed, then this value is reached or exceeded for 5 consecutive years (2010-2014). This demonstrates the key role knowledge on actual oxidation efficiency can play in decision making.

All input data, based on Fíflholt's green accounting and recategorization into IPCC model categories, is presented in Appendix B.

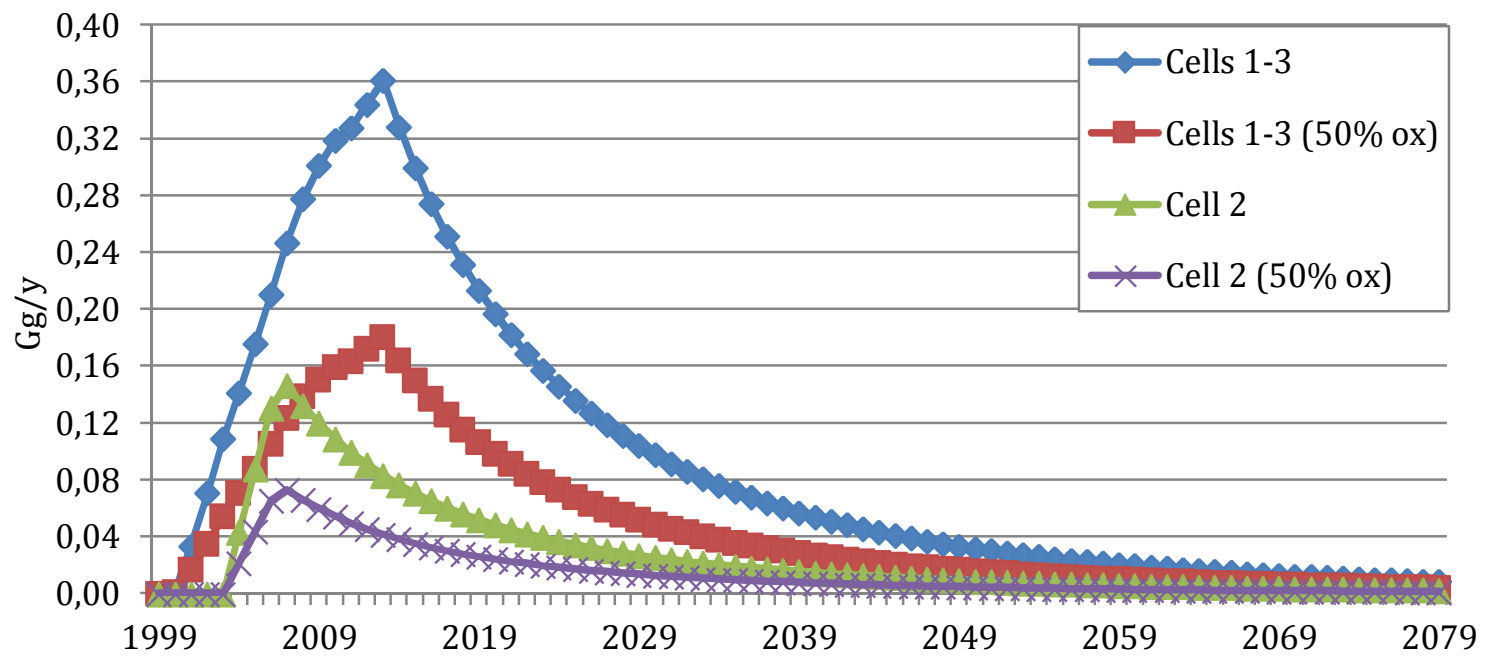

Figure 29 Estimated methane generation [Gg/y] at cells 1-3 and cell 2 of the Fiflholt landfill, assuming 0\% and 50\% methane oxidation, modelled using the localized IPCC (2006) first-order-decay model.

Passive recovery and treatment, e.g. via passive methane oxidizing biosystem, is generally considered appropriate when the methane generation is $<25 \mathrm{~m}^{3} \mathrm{CH}_{4} / \mathrm{h}$ (Scharff et al., 2011), which is the equivalent of $0.15 \mathrm{Gg} / \mathrm{y}$. As Figure 29 shows, this value was reached in 2007 at cell 2 according to the model results, but is inferior today. 



\section{Conclusions and Recommendations}

This master's thesis was performed at the initiative of The Icelandic Association of Local Authorities in order to study the extent of microbial methane oxidation in an Icelandic landfill cover, namely to gather information on the current oxidation capacity of the top cover at the Fíflholt landfill in West Iceland, $64^{\circ} \mathrm{N}$. The study, which took place mainly during the colder months of the year, specifically aimed at verifying if methane oxidation was taking place and assessing the oxidation efficiency in the top cover of Cell 2 at the landfill. This was done using the recently proposed gas profile method, which is based on the change in the ratio of $\mathrm{CO}_{2}$ to $\mathrm{CH}_{4}$ in the profile. The Fíflholt landfill has no gas recovery system; the generated gas therefore entirely escapes entirely through the top cover or possibly preferential pathways such as cracks or openings in the cover. The top cover is 1 $1.2 \mathrm{~m}$ thick, composed of $15-25 \mathrm{~cm}$ of crushed wood and approximately $1 \mathrm{~m}$ of excavated local soil. Cell 2 received waste between the years 2003 and 2006.

Sampling probes of different depths, $5-120 \mathrm{~cm}$, were installed at two locations at Cell 2, identified as $\mathrm{C} 2-\mathrm{N}$ and $\mathrm{C} 2-\mathrm{S}$, in proximity to landfill gas monitoring wells. Monthly point measurements were performed between August 2012 and February 2013, and in August 2013, covering typical atmospheric temperatures encountered throughout the year in Iceland. The landfill gas concentration and soil temperature at different depths was also measured on five occasions, and point gas fluxes were measured as a part of a parallel master's study. The landfill gas measured at monitoring wells exhibited typical concentrations of active landfills, i.e. $\mathrm{CH}_{4}$ ranging from $38 \%$ to $59 \%$. A soil sample from the cover was also studied in a laboratory, revealing the grain size distribution of a highly porous gravelly sand and $7 \%$ organic matter content. Metereological information was obtained from the on-site Icelandic Meteorological Office weather station.

The first aim of this study was to see if there was evidence that the landfill gas passing through the soil cover was being oxidized, even during the cold months of the year. The top cover at Fíflholt can indeed be considered as a passive biosystem, as high oxidation efficiencies were observed in the gas profiles at both locations during most sampling dates, seemingly beginning at the very bottom of the top cover. Atmospheric air penetrated deep into the top cover, judging by $\mathrm{O}_{2}$ and $\mathrm{N}_{2}$ concentrations up to $80 \mathrm{~cm}$ depth.

The second aim of this study was to assess the oxidation via the gas profile method (Gebert et al., 2011). Using the method, a general increase in oxidation efficiency was observed moving up the profile, typically reaching a maximum value $(91-97 \%$ at $\mathrm{C} 2-\mathrm{S}, 57-99 \%$ at $\mathrm{C} 2$ $\mathrm{N})$ between 30 and $60 \mathrm{~cm}$ depth. For the entire study period, the mean maximum efficiency was $59 \%$ at $\mathrm{C} 2-\mathrm{N}(60 \mathrm{~cm})$ and $77 \%$ at $\mathrm{C} 2-\mathrm{S}(30 \mathrm{~cm})$, or a mean value of $64 \%$ for both locations. Measurements made in the top $40 \mathrm{~cm}$ were influenced by the intrusion of atmospheric air, reducing the accuracy of oxidation efficiency calculations. Another factor of error in measurements is soil respiration, which was not taken into account in this study but can lead to overestimation of oxidation efficiencies in organic soils. Given the $7 \%$ organic matter content of the top cover soil, respiration was not assumed to play a major role in the total $\mathrm{CO}_{2}$ production, although this can only be verified through further investigation, e.g. batch tests. 
On two occasions little or no oxidation was observed, i.e. at both locations in December 2012, and at C2-N in August 2013. In December, it can be speculated that the lack of moisture in the soil due to a dry spell, coupled with a low atmospheric temperature of $0.1{ }^{\circ} \mathrm{C}$ and slight pressure drop, may have brought microbial activity to a standstill, although more documentation is needed to better understand events such as this.

The soil temperature was in the range of $2-12^{\circ} \mathrm{C}$ at $80 \mathrm{~cm}$ depth. Given the relatively high oxidation efficiencies obtained at low temperatures $\left(0-2^{\circ} \mathrm{C}\right)$ during the winter months, the study suggests that oxidation can take place throughout the year and that temperature may not be the most important controlling factor in the oxidation process. It was furthermore observed that the base of the top cover at $\mathrm{C} 2-\mathrm{N}$ was typically saturated, possibly due to the decomposing layer of crushed wood overlaying the waste body which might be prone to saturation during wet spells, altering upward gas transfer. This might explain a higher disparity of results and lower oxidation efficiencies obtained at $\mathrm{C} 2-\mathrm{N}$ than at $\mathrm{C} 2-\mathrm{S}$.

A third aim of this study was to discuss whether the $10 \%$ oxidation factor recommendation of the IPCC model for modern landfills was a reasonable value, particularly when measurements indicate higher oxidation efficiencies. It is always possible that a fraction of the landfill gas escapes through cracks in the cover, hot spots or other preferential pathways, foregoing oxidation in the cover, which is why it is important to remain on the conservative side. Measurements should therefore take into account spatial and temporal variability, including daily and seasonal changes, if a higher value than the default $10 \%$ is to be chosen.

This study suggests that the $10 \%$ default oxidation factor may underestimate the actual oxidation capacity of the cover at Fiflholt. This can only be verified however through a more thorough and continuous measurement campaign, including wide-spaced measurement techniques, meanwhile providing better results and a more accurate mean oxidation efficiency estimation.

In order to better understand the oxidation process under local climate conditions, the following recommendations are made, for Fíflholt or other landfills where gas emissions are under consideration:

- Continuous long-term measurements using the gas profile method are recommended, measuring gas concentrations, soil temperature and moisture and gathering meteorological data. Fixed-point chamber flux measurements might also prove informative. Measurements should ideally cover hot and cold periods of the year. Short-term measurement campaigns including e.g. bi-hourly measurements covering daily fluctuations would be informative.

- As compaction is directly related to the pore volume available for gas migration, the study of in-situ soil density, e.g. via cone test, and establishing a compaction curve by doing a Proctor compaction test in laboratory, would be helpful. The study of soil respiration would also be beneficial to the gas profile method in order to assess the role of respiration in the total production of $\mathrm{CO}_{2}$. This can e.g. be done via laboratory batch tests.

- Ideally, the gas profile method should be coupled with whole-site emission measurements, using meteorological method or plume techniques, to account for high and low emission areas, and possible gas escape points (vents or hot spots). 
- Different substrates can be tested in the top cover, based on a typical PMOB system, with a coarser gas distribution layer and finer methane oxidizing layer, using local available materials.

- It is recommended that environmental factors that seem to play an important role in the oxidation process, i.e. soil water content, atmospheric pressure and temperature, be studied in particular. Continuous measurement campaigns during periods of high and low temperatures, during notable changes in atmospheric pressure and particularly during periods of drought and high precipitation are of great interest. 


\section{References}

Abichou, T., Chanton, J., Powelson, D., Fleiger, J., Excoriaza, S., Lei, U. \& Stern, K., 2006. Methane flux and oxidation at two types of intermediate landfill covers. Waste Management $26 ; 1305-1312$.

Abichou, T., Powelson, D., Chanton, J., Escoriaza, S. \& Stern, J., 2006. Characterization of Methane Flux and Oxidation at a Solid Waste Landfill. Journal of Environmental Engineering 132: 220-228.

Arnalds, Ó. \& Óskarsson, H., 2009. Íslenskt jarðvegskort. Náttúrufræðingurinn 78 (3-4), bls. 107-121.

Atli Geir Júlíusson, 2011. Hauggasrannsóknir á urðunarstöðum á Íslandi. MS-thesis from the University of Iceland. Faculty of Civil and Environmental Engineering. School of Engineering and Natural Sciences, University of Iceland.

Bogner, J. \& Spokas, K., 1993. Landfill $\mathrm{CH}_{4}$ rates, fates and role in global carbon cycle. Chemosphere, 26; 366-386.

Bogner, J., Abdelrafie Ahmed, M., Diaz, C., Faaij, A., Gao, Q., Hashimoto, S., Mareckova, K, Pipatti, R. \& Zhang, T., 2007. Waste Management. In: Climate Change 2007: Mitigation. Contribution of Working Group III to the Fourth Assessment Report of the Intergovernmental Panel on Climate Change. Cambridge University Press, Cambridge, United Kingdom and New York, NY, USA.

Bogner, J., Meadows, M. \& Czepiel, P., 1997. Fluxes of methane between landfills and the atmosphere: natural and engineered controls. Soil Use and Management 13; 268-277.

Börjesson, G., Samuelsson, J. \& Chanton, J., 2007. Methane Oxidation in Swedish Landfills Quantified with the Stable Carbon Isotope Technique in Combination with an Optical Method for Emitted Methane. Environmental Science \& Technology, Vol. 41, no. 19.

Börjesson, G., Samuelsson, J., Chanton, J., Adolfsson, R., Galle, B. \& Svensson, B., 2009. A national landfill methane budget for Sweden based on field measurements, and an evaluation of IPCC models. Tellus, 61B; 424-435.

Börjesson, G., Sundh, I. \& Svensson, B., 2004. Microbial oxidation of CH4 at different temperatures in landfill cover soils. FEMS Microbiology Ecology 48; 305-312.

Cabral, A.R., Capanema, M.A., Gebert, J., Moreira, J.F., Jugnia, L.B., 2010b. Quantifying Microbial Methane Oxidation Efficiencies in Two Experimental Landfill Biocovers Using Stable Isotopes. Water Air Soil Pollut 209; 157-172. 
Cabral., A.R., Moreira, J.F.V. \& Jugnia, L.B., 2010a. Biocover Performance of Landfill Methane Oxidation: Experimental Results. Journal of Environmental Engineering, 08.2010; 785-793.

Chanton, J., Abichou, T., Langford, C., Spokas, K., Hater, G., Green, R., Goldsmith, D. \& Barlaz, M.W., 2011. Observations on the methane oxidation capacity of landfill soils. Waste Management 31; 014-925.

Chanton, J.P., Powelson, D.K. \& Green, R.B., 2009. Methane oxidation in landfill cover soils, is a 10\% default value reasonable? Journal of Environmental Quality 25;38(2):65463.

Christophersen, M. \& Kjeldsen, P., 2001. Lateral gas transport in soil adjacent to an old landfill: factors governing gas migration. Waste Management \& Research, 19; 144-159.

Christophersen, M., Holst, H., Chanton, J. \& Kjeldsen, P., 2001. Lateral gas transport in soil adjacent to an old landfill: factors governing emission and methane oxidation. Waste Management and Research, 19; 595-612.

Christophersen, M., Linderod, L., Jensen, P.E. \& Kjeldsen, P., 2000. Methane oxidation at low temperatures in soil exposed to landfill gas. Journal of Environmental Quality 29:19891997.

De Visscher, A., Pourcq, I. \& Chanton, J., 2004. Isotope fractionation effects by diffusion and methane oxidation in landfill cover soils. Journal of Geophysical Research 109, D18111.

EAI (The Environmental Agency of Iceland), 2002. Starfsleyfi fyrir urðunarstað Sorpurðun Vesturlands h.f., í landi Fíflholta, Borgarbyggð. Gefið út af fyrrum Hollustuvernd ríkisins, Mengunarvarnarsviði, nú Umhverfisstofnun.

EAI, 2012. Emissions of greenhouse gases in Iceland from 1990 to 2010. National Inventory Report 2012. Submitted under the United Nations Framework Convention on Climate Change and the Kyoto Protocol. Environment Agency of Iceland.

EAI, 2012b. Viðmið um hvencer krafist er söfnunar hauggass á urðunarstöðum, sbr. ákvœei reglugerðar $n r$. 738/2003 um urðun úrgangs.

EFLA Consulting Engineers, 2012. Urðunarstaður $i$ Fiflholtum. Áhoettumat vegna starfsleyfis. Unnið fyrir Sorpurðun Vesturlands hf.

Einarsson, M., 1984. World Survey of Climatology: 15: Climates of the Oceans. Climate of Iceland. Elsevier, Amsterdam, pp 673-697.

Einola, J.K.M., Kettunen, R.H. \& Rintala, J.A., 2007. Responses of methane oxidation to temperature and water content in cover soil of a boreal landfill. Soil Biology and Biochemistry, 39, 1156-1164.

European Environmental Agency (EEA), 2009. Annual European Community Greenhouse Gas Inventory 19902-007 and Inventory Report 2007. Submission to the UNFCCC Secretariat. EEA Technical Report, No. 4. 2009; Annex I Key category analysis. 
Fang, C. \& Moncrieff, J.B., 2001. The dependence of soil $\mathrm{CO}_{2}$ efflux on temperature. Soil Biol. Biochem. 33; 155-165.

Forster, P., Ramaswamy, V., ARtazo, P., Berntsen, T., Betts, R., Fahey, D.W., Haywood, J., Lean, J.,, Lowe, D.C., Myhre, G., Nganga, J., Prinn, R., Raga, G., Schulz, M. \& Van Dorland, R., 2007. Changes in atmospheric constituents and in radioactive forcing. In : Climate Change 2007: The Physical Science Basis. Contribution of Working Group I to the Fourth Assessment Report of the Intergovernmental Panel on Climate Change. Cambridge University Press, Cambridge, United Kingdom and New York, NY, USA.

Gebert, J. \& Gröngröft, A., 2006. Performance of a passively vented field-scale biofilter for the microbial oxidation of landfill methane. Waste Management. 26, 399-407.

Gebert, J., Gröngröft, A. \& Pfeiffer, E.M., 2011. Relevance of soil physical properties for the microbial oxidation of methane in landfill covers. Soil Biology \& Biochemistry 43; 1759-1767.

Gebert, J., Rachor, I., Gröngröft, A. \& Pfeiffer, E.M., 2011a. Temporal variability of soil gas composition in landfill covers. Waste Management 31; 935-945.

Gebert, J., Röwer, I.U., Scharff, H., Roncato, C.D.L.\& Cabral, A.R., 2011b. Can soil gas profiles be used to assess microbial CH4 oxidation in landfill covers? Waste Management 31; 987-994.

Geotechnical Instruments. GA 2000 Plus Gas Analyser Operating Manual. http://www.geotech.co.uk

Guicharnaud, T., Arnalds, Ó. \& Paton, G.I., 2010. Short term changes of microbial processes in Icelandic soils to increasing temperatures. Biogeosciences, 7, 671-682.

Hanson, R.S., \& Hanson, T.E., 1996. Methanotrophic bacteria. Microbiol. Rev. 60; 439471.

Harstad, K. edt., 2006. Handling and assessment of leachates from municipal solid waste landfills in the Nordic countries. TemaNord 2006: 594.

Huber-Humer, M. \& Lechner, P, 2003. Effect of methane oxidation on the water balance of the landfill cover and the vegetation layer. In: Proc. Sardinia '03. Ninth International Waste Management and Landfill Symposium, CISA Environmental Sanitary Engineering Centre, Cagliari, Italy.

Huber-Humer, M., Röder, S. \& Lechner, P., 2009. Approaches to assess biocover performance on landfills. Waste Management; 2092-2104.

IPCC, 2006. 2006 IPCC Guidelines for National Greenhouse Gas Inventories, Volume 5, Chapter 3. Solid Waste Disposal.

IPCC, 2007. Intergovernmental Panel on Climate Change Working Group II, Fourth Assessment Report (2007). Climate Change 2007: Mitigation of Climate Change, http;//www.ipcc.ch/SPM040507.pdf 
Jugnia, L.B., Benichou, S.A., Fortin, N., Cabral., A.R. \& Greer, C.W., 2009. Diversity and Dynamics of Methanotrophs within an Experimental Landfill Cover Soil. Soil Biology \& Biochemistry, Vol. 73, No. 5; 1479-1487.

Jugnia, L.B., Cabral., A.R. \& Greer, C.W., 2008. Biotic methane oxidation within an instrumented experimental landfill cover. Ecological Engineering 33; 102-109.

Kamsma, R.P.M \& Meyles, C.A., 2003. Landfill Gas Formation in Iceland. A study on Landfill Gas Formation in landfills in Iceland, in relation to the implentation of the Landfill Directive into the national law.

Kjeldsen, P. \& Fischer, E.V., 1995. Landfill gas migration - field investigations at Skellingsted landfill, Denmark. Waste Management \& Research 13; 467-484.

Lohila, A., Laurila, T., Tuovinen, J.P., Aurela, M., Hatakka, J., Thum, T., Pihlatie, M., Rinne, J. \& Vesala, T., 2007. Micrometeorological Measurements of Methane and Carbon Dioxide Fluxes at a Municipal Landfill. Environmental Science and Technology 41; 27172722.

Mannvit, 2012. Minnisblað. Niðurstöður afkastamoelinga á borholum. Mannvit verkfræðistofa.

Ministry for the Environment and Natural Resources (Umhverfis- og auðlindaráðuneytið), 2013. Landsáætlun um meðhöndlun úrgangs 2013-2024. Úrgangsstjórnun til framtíðar.

Orradóttir, B., Archer, S.R., Arnalds, Ó., Wilding, L.P., Thurow, T.L., 2008. Infiltration in Icelandic Andisols: the role of vegetation and soil frost. Arct. Antarct. Alp. Res., 20; 412421.

Parent, S.E. \& Cabral, A., 2006. Design of inclined covers with capillary barrier effect. Geotechnical and Geological Engineering, 24;689-719.

Peel, M.C., Finlayson, B.L. and McMahon, T.A., 2007. Updated world map of the KöppenGeiger climate classification. Hydrol. Earth Syst. Sci., 11; 1633-1644.

Price, P.B., \& Sowers, T., 2004. Temperature dependence of metabolic rates for microbial groqth, maintenance and survival. Proceedings of the National Academy of Sciences of the United States of America, 101; 4631-4636.

Rachor, I., Streese-Kleeberg, J. \& Gebert, J., 2009. Spatial and temporal variability of gas emissions from old landfills. In: Proceedings Sardinia 2009, Twelfth International Waste Management and Landfill Symposium. S. Margherita di Pula, Cagliari, Italy. CISA, Italy.

Ræktunarsamband Flóa og Skeiða, 2009. Borskýrslur.

Ritzkowski, M. \& Stegmann, R., 2007. Controlling greenhouse gas emissions through landfill in situ aeration. International Journal of Greenhouse Gas Control, Vol.1, Issue 3; 281-288.

Roncato, C.D.L. and Cabral, A., 2012. Evaluation of Methane Oxidation Efficiency of Two Biocovers: Field and Laboratory Results. Journal of Environmental Engineering, 138:2. 
Röwer, I.U., Geck, C., Gebert, J. and Pfeiffer, E.M., 2011. Spatial variability of soil gas concentration and methane oxidation capacity in landfill covers. Waste Management 31; 926-934.

Scharff, H. \& Jacobs, J., 2006. Applying guidance for methane emission estimation for landfills. Waste Management 26; 417-429.

Scharff, H., Hansen, J. \& Gústafsson, L., 2011. Mission report: TAIEX Assistance Iceland concerning the implementation of the EU Landfill Directive and landfill gas control. TAIEX reference 45985.

Scheutz, C. \& Kjeldsen, P., 2004. Environmental factors influencing attenuation of methane and hydrochlorofluorocarbons in landfill cover soils. Journal of Environmental Quality, 33, 72-79.

Scheutz, C., \& Kjeldsen, P., 2005. Biodegradation of trace gasses in simulated landfill soil cover. J. Air Waste Manage. Assoc. 55, 878-885.

Scheutz, C., Fredenslund, A.M., Nedenskov, J., Samuelsson, J. \& Kjeldsen, P., 2011a. Gas production, composition and emission at a modern disposal site receiving waste with a low-organic content. Waste Management 31; 946-955.

Scheutz, C., Kjeldsen, P., Bogner, J.E., Visscher, A., Gebert, J., Hilger, H.A., Huber-Humer, M. \& Spokas, K., 2009. Microbial methane oxidation processes and technologies for mitigation of landfill gas emissions. Waste Management \& Research, 27; 409-455.

Scheutz, C., Samuelsson, J., Fredenslund, A.M. \& Kjeldsen, P., 2011. Quantification of multiple methane emission sources at landfills using a double tracer technique. Waste Management, Volume 31, Issue 5; 1009-1017.

Schroth, M.H., Eugster, W., Gómez, K.E., Gonzalez-Gil, G., Niklaus, P.A. \& Oester, P., 2012. Above- and below-ground methane fluxes and methanotrophic activity in a landfillcover soil. Waste Management 32; 879-889.

Streese-Kleeberg, J., Rachor, I., Gebert, J. \& Stegmann, R., 2011. Use of gas push-pull tests for the measurement of methane oxidation in different landfill cover soils. Waste Management 31; 995-1001.

SWMWIRO (The Solid Waste Management of West Iceland Regional Office / Sorpurðun Vesturlands), 2012. Green Accounting 2004 - 2012.

The Icelandic Road and Coastal Administration (Vegagerðin), 2006. Efnisrannsóknir og efniskröfur. Leiðbeiningar við hönnun, framleiðslu og framkvæmd. Viðauki 1: Lýsing á prófunaraðferðum.

Trégourès, A., Beneito, A., Berne, P., Gonze, M.A., Sabroux, J.C., Savanne, D., Pokryszka, Z., Tauziede, C., Cellier, P., Laville, P., Milward, R., Arnaud, A., Levy, F. \& Burkhalter, R., 1999. Comparison of seven methods for measuring methane flux at a municipal solid waste landfill site. Waste Management 17; 453-458.

VGK Hönnun, 2007. Sameiginleg svœðisácetlun um meðhöndlun úrgangs. Niðurstöður ráðgjafa um meðhöndlun lifrcens úrgangs og urðunarstaði. Samantekt fyrir verkefnisstjórn 
(Sorpa bs., Sorpstöð Suðurlands bs., Sorpeyðingarstöð Suðurnesja sf. og Sorpurðun Vesturlands hf.).

West Systems, 2007. Portable diffuse flux meter. Carbon dioxide, Methane \& Hydrogen sulfide. Handbook. Release 7.00 July 2007. http://www.westsystems.com 


\section{Appendix A: Gas Profile Results}

\begin{tabular}{|c|c|c|c|c|c|c|c|c|c|}
\hline \multicolumn{10}{|c|}{ C2-S } \\
\hline & $\begin{array}{l}\text { Depth } \\
(\mathrm{cm})\end{array}$ & $\begin{array}{l}\mathrm{CH}_{4} \\
(\%)\end{array}$ & $\begin{array}{l}\mathrm{CO}_{2} \\
(\%)\end{array}$ & $\begin{array}{l}\mathrm{O}_{2} \\
(\%)\end{array}$ & $\begin{array}{l}N_{2} \\
(\%)\end{array}$ & $\begin{array}{l}\text { ratio } \\
\mathrm{CO}_{2} / \mathrm{CH}_{4}\end{array}$ & $\begin{array}{l}\text { Non diluted } \mathrm{CH}_{4} \\
(\%)\end{array}$ & $\begin{array}{l}\text { Oxidized } \mathrm{CH}_{4} \\
\text { (\%) }\end{array}$ & $\begin{array}{l}\text { Eff } \\
(\%)\end{array}$ \\
\hline \multirow{5}{*}{ 17.10.2012 } & 5 & 0.40 & 0.35 & 21.80 & 77.45 & 0.88 & 53.3 & 2.5 & 4.4 \\
\hline & 20 & 0.43 & 2.73 & 19.20 & 77.60 & 6.31 & 13.7 & 42.1 & 75.5 \\
\hline & 30 & 0.57 & 10.97 & 14.67 & 73.63 & 19.35 & 4.9 & 50.9 & 91.2 \\
\hline & 120 & 47.00 & 34.60 & 7.60 & 10.90 & 0.74 & 57.6 & -1.8 & -3.2 \\
\hline & $3-5 \mathrm{~m}$ & $55.80 *$ & 44.00 & 0.00 & 0.20 & 0.79 & 55.9 & -0.1 & -0.2 \\
\hline \multirow{4}{*}{ 18.11.2012 } & 5 & 0.00 & 0.10 & 22.10 & 77.80 & - & 0.0 & 58.0 & 100.0 \\
\hline & 10 & 0.00 & 0.30 & 22.00 & 77.70 & - & 0.0 & 58.0 & 100.0 \\
\hline & 20 & 0.00 & 0.10 & 22.00 & 77.90 & - & 0.0 & 58.0 & 100.0 \\
\hline & 120 & 58.03* & 39.00 & 3.08 & 1.43 & 0.67 & 59.8 & -1.8 & -3.1 \\
\hline \multirow{7}{*}{12.12 .2012} & 5 & 0.00 & 0.00 & 22.60 & 77.40 & - & - & - & - \\
\hline & 10 & N.A. & & & & & & & \\
\hline & 20 & 30.94 & 10.44 & 1.96 & 56.60 & 0.34 & 74.8 & -13.5 & -21.9 \\
\hline & 30 & 19.43 & 9.33 & 1.53 & 69.73 & 0.48 & 67.6 & -6.2 & -10.2 \\
\hline & 40 & 31.73 & 10.93 & 1.35 & 55.98 & 0.34 & 74.4 & -13.1 & -21.3 \\
\hline & 80 & 32.33 & 18.90 & 4.67 & 44.11 & 0.58 & 63.1 & -1.8 & -2.9 \\
\hline & 120 & $61.32 *$ & 38.35 & 1.18 & 1.63 & 0.63 & 61.5 & -0.2 & -0.3 \\
\hline \multirow{2}{*}{ 21.01.2013 } & 5 & 0.00 & 0.00 & 21.50 & 78.50 & - & - & - & - \\
\hline & 10 & 0.00 & 0.05 & 21.60 & 78.35 & - & 0.0 & 58.1 & 100.0 \\
\hline \multirow{7}{*}{28.02 .2013} & 10 & 0.48 & 0.43 & 22.15 & 76.95 & 0.89 & 52.8 & 8.9 & 14.4 \\
\hline & 20 & 0.18 & 0.25 & 22.05 & 77.50 & 1.43 & 41.2 & 20.5 & 33.2 \\
\hline & 30 & 0.17 & 2.47 & 19.77 & 77.60 & 14.80 & 6.3 & 55.3 & 89.7 \\
\hline & 40 & 0.08 & 2.56 & 19.70 & 77.66 & 32.00 & 3.0 & 58.6 & 95.1 \\
\hline & 80 & 20.33 & 14.97 & 12.80 & 51.93 & 0.74 & 57.6 & 4.1 & 6.6 \\
\hline & 120 & $61.67 *$ & 36.70 & 2.57 & 0.13 & 0.60 & 62.7 & -1.0 & -1.7 \\
\hline & $3-5 \mathrm{~m}$ & 51.90 & 39.80 & 0.50 & 7.80 & 0.77 & 56.6 & 5.1 & 8.2 \\
\hline \multirow{8}{*}{22.08 .2013} & 5 & 0.52 & 0.44 & 21.02 & 78.10 & 0.85 & 54.2 & 4.7 & 8.0 \\
\hline & 10 & 0.30 & 0.25 & 21.10 & 78.35 & 0.83 & 54.5 & 4.4 & 7.4 \\
\hline & 20 & 0.17 & 0.33 & 21.10 & 78.37 & 2.00 & 33.3 & 25.6 & 43.4 \\
\hline & 30 & 0.15 & 9.78 & 14.18 & 75.93 & 65.17 & 1.5 & 57.4 & 97.4 \\
\hline & 40 & N.A. & & & & & & & \\
\hline & 80 & 23.86 & 26.71 & 9.61 & 39.80 & 1.12 & 47.2 & 11.7 & 19.9 \\
\hline & 120 & 55.20 & 41.40 & 1.74 & 1.72 & 0.75 & 57.1 & 1.8 & 3.0 \\
\hline & $3-5 \mathrm{~m}$ & $58.90 *$ & 40.70 & 0.40 & 0.00 & 0.69 & 59.1 & -0.2 & -0.4 \\
\hline
\end{tabular}

* Methane concentration marked in bold used to calculate Eff $\mathrm{fx}_{\text {. }}$

** Methane concentration of $55 \%$ used to calculate $\mathrm{Eff}_{\mathrm{ox}}$. 


\begin{tabular}{|c|c|c|c|c|c|c|c|c|c|}
\hline \multicolumn{10}{|c|}{$\mathrm{C} 2-\mathrm{N}$} \\
\hline & $\begin{array}{l}\text { Depth } \\
\text { (cm) }\end{array}$ & $\mathrm{CH}_{4}(\%)$ & $\begin{array}{l}\mathrm{CO}_{2} \\
(\%)\end{array}$ & $\begin{array}{l}\mathrm{O}_{2} \\
(\%)\end{array}$ & $\begin{array}{l}N_{2} \\
(\%)\end{array}$ & $\begin{array}{l}\text { ratio } \\
\mathrm{CO}_{2} / \mathrm{CH}_{4}\end{array}$ & $\begin{array}{l}\text { Non diluted } \mathrm{CH}_{4} \\
(\%)\end{array}$ & $\begin{array}{l}\text { Oxidized } \mathrm{CH}_{4} \\
\text { (\%) }\end{array}$ & $\begin{array}{l}\text { Eff }_{o x} \\
(\%)\end{array}$ \\
\hline \multirow{8}{*}{$\begin{array}{l}16.08 .2012 \\
* *\end{array}$} & 5 & 0.30 & 6.30 & 12.60 & 73.40 & 21.0 & 4.5 & 50.5 & 91.7 \\
\hline & 10 & 0.70 & 1.10 & 20.40 & 77.80 & 1.6 & 38.9 & 16.1 & 29.3 \\
\hline & 20 & 1.10 & 10.90 & 14.40 & 73.40 & 9.9 & 9.2 & 45.8 & 83.3 \\
\hline & 30 & 0.30 & 4.90 & 13.10 & 81.80 & 16.3 & 5.8 & 49.2 & 89.5 \\
\hline & 40 & 2.30 & 9.30 & 10.60 & 77.80 & 4.0 & 19.8 & 35.2 & 63.9 \\
\hline & 60 & 0.40 & 15.90 & 9.20 & 74.50 & 39.8 & 2.5 & 52.5 & 95.5 \\
\hline & 80 & 2.40 & 11.70 & 12.70 & 73.40 & 4.9 & 17.0 & 38.0 & 69.1 \\
\hline & 120 & N.A. & & & & & & & \\
\hline \multirow{8}{*}{$\begin{array}{l}02.09 .2012 \\
* *\end{array}$} & 5 & 0.60 & 1.90 & 20.20 & 77.30 & 3.2 & 24.0 & 31.0 & 56.4 \\
\hline & 10 & 5.50 & 11.20 & 15.00 & 68.30 & 2.0 & 32.9 & 22.1 & 40.1 \\
\hline & 20 & 12.40 & 21.90 & 8.10 & 57.50 & 1.8 & 36.2 & 18.8 & 34.3 \\
\hline & 30 & 5.20 & 16.80 & 9.50 & 68.10 & 3.2 & 23.6 & 31.4 & 57.0 \\
\hline & 40 & 14.20 & 26.40 & 3.90 & 55.40 & 1.9 & 35.0 & 20.0 & 36.4 \\
\hline & 60 & 12.10 & 25.20 & 6.00 & 56.80 & 2.1 & 32.4 & 22.6 & 41.0 \\
\hline & 80 & 31.10 & 31.10 & 3.30 & 34.40 & 1.0 & 50.0 & 5.0 & 9.1 \\
\hline & 120 & N.A. & & & & & & & \\
\hline \multirow{9}{*}{17.10 .2012} & 5 & 0.80 & 3.55 & 18.65 & 77.15 & 4.4 & 18.4 & 33.0 & 64.2 \\
\hline & 10 & 23.70 & 21.60 & 9.17 & 45.63 & 0.9 & 52.3 & -0.9 & -1.8 \\
\hline & 20 & 3.57 & 6.33 & 16.77 & 73.37 & 1.8 & 36.0 & 15.4 & 29.9 \\
\hline & 30 & 2.17 & 10.83 & 12.63 & 74.33 & 5.0 & 16.7 & 34.7 & 67.6 \\
\hline & 40 & 15.20 & 19.67 & 7.90 & 57.23 & 1.3 & 43.6 & 7.8 & 15.2 \\
\hline & 60 & 0.77 & 11.73 & 11.37 & 76.13 & 15.3 & 6.1 & 45.3 & 88.1 \\
\hline & 80 & 16.50 & 19.66 & 8.62 & 55.26 & 1.2 & 45.6 & 5.8 & 11.2 \\
\hline & 120 & N.A. & & & & & & & \\
\hline & $3-5 m$ & $51.40 *$ & 41.10 & 0.90 & 7.10 & 0.8 & 55.6 & -4.2 & -8.1 \\
\hline \multirow{8}{*}{$\begin{array}{l}18.11 .2012 \\
* *\end{array}$} & 5 & 0.17 & 0.33 & 21.20 & 78.27 & 2.0 & 33.3 & 21.7 & 39.4 \\
\hline & 10 & 5.50 & 7.37 & 16.87 & 70.30 & 1.3 & 42.7 & 12.3 & 22.3 \\
\hline & 20 & 2.13 & 6.30 & 17.40 & 74.17 & 3.0 & 25.3 & 29.7 & 54.0 \\
\hline & 30 & 4.38 & 12.20 & 12.95 & 70.50 & 2.8 & 26.4 & 28.6 & 52.0 \\
\hline & 40 & 9.50 & 14.70 & 12.48 & 63.40 & 1.5 & 39.3 & 15.7 & 28.6 \\
\hline & 60 & 1.91 & 15.41 & 10.73 & 71.98 & 8.1 & 11.0 & 44.0 & 79.9 \\
\hline & 80 & 21.02 & 29.96 & 3.90 & 45.14 & 1.4 & 41.2 & 13.8 & 25.0 \\
\hline & 120 & N.A. & & & & & & & \\
\hline \multirow{8}{*}{12.12 .2012} & 5 & 1.30 & 1.20 & 20.73 & 76.75 & 0.9 & 52.0 & 3.8 & 6.8 \\
\hline & 10 & 48.56 & 32.00 & 2.94 & 16.56 & 0.7 & 60.3 & -4.5 & -8.0 \\
\hline & 20 & 51.06 & 32.44 & 1.84 & 14.66 & 0.6 & 61.1 & -5.3 & -9.6 \\
\hline & 30 & 48.63 & 30.01 & 1.06 & 20.29 & 0.6 & 61.8 & -6.0 & -10.8 \\
\hline & 40 & 49.50 & 31.62 & 1.37 & 17.52 & 0.6 & 61.0 & -5.2 & -9.4 \\
\hline & 60 & 49.58 & 29.98 & 1.38 & 19.06 & 0.6 & 62.3 & -6.5 & -11.7 \\
\hline & 80 & $55.80 *$ & 34.94 & 1.32 & 7.98 & 0.6 & 61.5 & -5.7 & -10.2 \\
\hline & 120 & 38.48 & 25.22 & 8.18 & 28.16 & 0.7 & 60.4 & -4.6 & -8.3 \\
\hline \multirow{9}{*}{$\begin{array}{l}21.01 .2013 \\
* *\end{array}$} & 5 & 0.90 & 0.82 & 21.03 & 77.23 & 0.9 & 52.4 & 2.6 & 6.8 \\
\hline & 10 & 1.23 & 0.98 & 20.68 & 77.15 & 0.8 & 55.7 & -0.7 & -1.8 \\
\hline & 20 & 1.63 & 4.33 & 19.03 & 74.97 & 2.7 & 27.4 & 27.6 & 73.1 \\
\hline & 30 & 5.55 & 15.25 & 12.33 & 66.85 & 2.7 & 26.7 & 28.3 & 74.9 \\
\hline & 40 & 16.77 & 29.57 & 5.30 & 48.43 & 1.8 & 36.2 & 18.8 & 49.8 \\
\hline & 60 & 7.05 & 30.13 & 3.35 & 59.45 & 4.3 & 19.0 & 36.0 & 95.3 \\
\hline & 80 & 25.38 & 33.50 & 2.23 & 38.90 & 1.3 & 43.1 & 11.9 & 31.5 \\
\hline & 120 & N.A. & & & & & & & \\
\hline & $3-5 \mathrm{~m}$ & 37.80 & 27.80 & 8.30 & 26.10 & 0.7 & 57.6 & -2.6 & -6.9 \\
\hline \multirow{9}{*}{ 28.02.2013 } & 5 & 0.97 & 1.30 & 21.00 & 76.73 & 1.3 & 42.6 & 15.0 & 26.0 \\
\hline & 10 & 0.23 & 0.98 & 21.33 & 77.53 & 4.3 & 18.8 & 38.9 & 67.4 \\
\hline & 20 & 0.80 & 6.67 & 18.93 & 73.63 & 8.3 & 10.7 & 46.9 & 81.4 \\
\hline & 30 & 0.10 & 4.50 & 19.50 & 75.90 & 45.0 & 2.2 & 55.4 & 96.2 \\
\hline & 40 & 0.10 & 10.90 & 16.48 & 72.53 & 109.0 & 0.9 & 56.7 & 98.4 \\
\hline & 60 & 0.10 & 17.60 & 14.55 & 67.75 & 176.0 & 0.6 & 57.0 & 99.0 \\
\hline & 80 & 1.33 & 33.88 & 3.28 & 61.55 & 25.6 & 3.8 & 53.8 & 93.5 \\
\hline & 120 & N.A. & & & & & & & \\
\hline & $3-5 \mathrm{~m}$ & $57.60 *$ & 33.50 & 0.80 & 8.10 & 0.6 & 63.2 & -5.6 & -9.8 \\
\hline \multirow{9}{*}{22.08 .2013} & 5 & 0.65 & 0.40 & 20.98 & 77.98 & 0.6 & 61.9 & -13.1 & -26.7 \\
\hline & 10 & 0.38 & 0.40 & 20.93 & 78.28 & 1.1 & 48.4 & 0.5 & 0.9 \\
\hline & 20 & 10.95 & 4.78 & 16.78 & 67.50 & 0.4 & 69.6 & -20.8 & -42.6 \\
\hline & 30 & 25.24 & 20.98 & 9.24 & 44.50 & 0.8 & 54.6 & -5.8 & -11.8 \\
\hline & 40 & 42.45 & 33.65 & 3.65 & 20.27 & 0.8 & 55.8 & -6.9 & -14.2 \\
\hline & 60 & 48.84* & 33.96 & 1.64 & 15.54 & 0.7 & 59.0 & -10.1 & -20.8 \\
\hline & 80 & 36.21 & 24.11 & 8.16 & 31.54 & 0.7 & 60.0 & -11.2 & -22.9 \\
\hline & 120 & N.A. & & & & & & & \\
\hline & $3-5 \mathrm{~m}$ & 46.90 & 39.50 & 0.40 & 13.20 & 0.8 & 54.3 & -5.4 & -11.1 \\
\hline
\end{tabular}





\section{Appendix B: Fíflholt Waste Inventory}

\begin{tabular}{|c|c|c|c|c|c|c|c|c|c|c|c|c|c|c|}
\hline \multirow{2}{*}{$\begin{array}{l}\text { FÍFLHOLT - IPCC WASTE CATEGORIES } \\
\text { (Sorpurðun Vesturlands, 2004 - 2012) }\end{array}$} & \multicolumn{14}{|c|}{ Waste quantities $(\mathrm{kg})$ per year } \\
\hline & 1999 & 2000 & 2001 & 2002 & 2003 & 2004 & 2005 & $2006^{*}$ & 2007 & 2008 & 2009 & 2010 & 2011 & 2012 \\
\hline Mixed domestic waste (total, non-categorized) & 343,631 & $5,488,355$ & $7,093,148$ & $7,915,914$ & $7,556,342$ & $8,443,140$ & $7,483,340$ & $5,825,440$ & $6,994,090$ & $5,947,480$ & $6,218,460$ & $5,784,880$ & $6,768,380$ & $6,399,860$ \\
\hline \multicolumn{15}{|l|}{ FOOD } \\
\hline Mixed domestic waste (food 27\%) & 92,780 & $1,481,856$ & $1,915,150$ & $2,137,297$ & $2,040,212$ & $2,279,648$ & $2,020,502$ & $1,572,869$ & $1,888,404$ & $1,605,820$ & $1,678,984$ & $1,561,918$ & $1,827,463$ & $1,727,962$ \\
\hline Waste from the handling of meat and fish & & & & & & & & & & & 352,960 & 28,660 & 13,180 & 117,620 \\
\hline Waste from shellfish and shrimp processing & 160 & 2,548 & 3,293 & 3,675 & 3,508 & 3,920 & 16,340 & & & & & & & \\
\hline From canteens/kitchens (biodegradable waste) & & & & & 0 & & 5,860 & 2,140 & 489,440 & & & & & \\
\hline TOT & 92,940 & $1,484,404$ & $1,918,443$ & $2,140,972$ & $2,043,720$ & $2,283,568$ & $2,042,702$ & $1,575,009$ & $2,377,844$ & $1,605,820$ & 2,031,944 & $1,590,578$ & $1,840,643$ & $1,845,582$ \\
\hline \multicolumn{15}{|l|}{ GARDEN } \\
\hline Mixed domestic waste (garden 1\%) & 3,436 & 54,884 & 70,931 & 79,159 & 75,563 & 84,431 & 74,833 & 58,254 & 69,941 & 59,475 & 62,185 & 57,849 & 67,684 & 63,999 \\
\hline Forestry waste & & & & & 0 & & & & 2,940 & 9,760 & & & & \\
\hline Garden waste & 276 & 4,407 & 5,696 & 6,357 & 6,068 & 6,780 & 27,940 & 32,960 & 12,720 & 6,880 & & & & \\
\hline тот & 3,712 & 59,291 & 76,627 & 85,516 & 81,631 & 91,211 & 102,773 & 91,214 & 85,601 & 76,115 & 62,185 & 57,849 & 67,684 & 63,999 \\
\hline \multicolumn{15}{|l|}{ PAPER } \\
\hline Mixed domestic waste (paper 27\%) & 92,780 & $1,481,856$ & $1,915,150$ & $2,137,297$ & $2,040,212$ & $2,279,648$ & $2,020,502$ & $1,572,869$ & $1,888,404$ & $1,605,820$ & $1,678,984$ & $1,561,918$ & $1,827,463$ & $1,727,962$ \\
\hline Paper and cardboard, magazines and newspapers & 37 & 598 & 773 & 863 & 823 & 920 & 4,280 & 2,180 & & & & 13,900 & & \\
\hline тот & 92,818 & $1,482,454$ & $1,915,923$ & $2,138,159$ & $2,041,036$ & $2,280,568$ & $2,024,782$ & $1,575,049$ & $1,888,404$ & $1,605,820$ & $1,678,984$ & $1,575,818$ & $1,827,463$ & $1,727,962$ \\
\hline \multicolumn{15}{|l|}{ WOOD } \\
\hline Mixed domestic waste (wood 1\%) & 3,436 & 54,884 & 70,931 & 79,159 & 75,563 & 84,431 & 74,833 & 58,254 & 69,941 & 59,475 & 62,185 & 57,849 & 67,684 & 63,999 \\
\hline Chips, cuttings, used wood, veneer etc. & 29,442 & 470,237 & 607,734 & 678,228 & 647,420 & 723,400 & $1,152,030$ & $2,180,210$ & 565,920 & 877,420 & 668,840 & 519,180 & 722,660 & 877,980 \\
\hline TOT & 32,878 & 525,120 & 678,665 & 757,387 & 722,983 & 807,831 & $1,226,863$ & $2,238,464$ & 635,861 & 936,895 & 731,025 & 577,029 & 790,344 & 941,979 \\
\hline TEXTLLE & & & & & & & & & & & & & & \\
\hline
\end{tabular}




\begin{tabular}{|c|c|c|c|c|c|c|c|c|c|c|c|c|c|c|}
\hline Mixed domestic waste (textile $3 \%$ ) & 10,309 & 164,651 & 212,794 & 237,477 & 226,690 & 253,294 & 224,500 & 174,763 & 209,823 & 178,424 & 186,554 & 173,546 & 203,051 & 191,996 \\
\hline тот & 10,309 & 164,651 & 212,794 & 237,477 & 226,690 & 253,294 & 224,500 & 174,763 & 209,823 & 178,424 & 186,554 & 173,546 & 203,051 & 191,996 \\
\hline \multicolumn{15}{|l|}{ NAPPIES } \\
\hline Mixed domestic waste (nappies 9\%) & 30,927 & 493,952 & 638,383 & 712,432 & 680,071 & 759,883 & 673,501 & 524,290 & 629,468 & 535,273 & 559,661 & 520,639 & 609,154 & 575,987 \\
\hline ТОТ & 30,927 & 493,952 & 638,383 & 712,432 & 680,071 & 759,883 & 673,501 & 524,290 & 629,468 & 535,273 & 559,661 & 520,639 & 609,154 & 575,987 \\
\hline \multicolumn{15}{|l|}{ SLUDGE } \\
\hline Manure & & & & & & & & & & & & & & 4,500 \\
\hline Sludge / waste from septic tanks & 830 & 13,261 & 17,138 & 19,126 & 18,257 & 20,400 & 214,980 & 70,540 & 34,240 & 175,320 & 327,080 & 231,520 & 230,520 & 314,200 \\
\hline тот & 830 & 13,261 & 17,138 & 19,126 & 18,257 & 20,400 & 214,980 & 70,540 & 34,240 & 175,320 & 327,080 & 231,520 & 230,520 & 318,700 \\
\hline \multicolumn{15}{|l|}{ INERT } \\
\hline Mixed domestic waste (inert 32\%) & 109,962 & $1,756,274$ & $2,269,807$ & $2,533,093$ & $2,418,029$ & $2,701,805$ & $2,394,669$ & $1,864,141$ & $2,238,109$ & $1,903,194$ & $1,989,907$ & $1,851,162$ & $2,165,882$ & $2,047,955$ \\
\hline Fishing gear & 2,285 & 36,493 & 47,164 & 52,634 & 50,244 & 56,140 & 55,740 & 37,460 & & & 17,020 & 15,680 & 44,720 & 60,820 \\
\hline ?(04.01.00) & & & & & 0 & & & 3,800 & & & & & & \\
\hline Agricultural plastic & 2,271 & 36,272 & 46,878 & 52,316 & 49,939 & 55,800 & 81,460 & 52,140 & & & & & & \\
\hline Used tires & & & & & 0 & & 31,440 & & & & & & & \\
\hline Concrete, bricks, tiles, ceramics and plaster materials & 2,299 & 36,714 & 47,449 & 52,953 & 50,548 & 56,480 & 41,240 & 17,920 & 46,500 & 49,660 & & & & 12,180 \\
\hline Concrete & & & & & 0 & & 1,800 & 14,520 & & & & & & \\
\hline Glass from construction work (2009-2012: Glass) & & & & & 0 & & & & 14,460 & & 16,240 & 26,300 & 25,300 & \\
\hline Tiles and ceramics & & & & & 0 & & 600 & 600 & 700 & 1,120 & 440 & 5,220 & 4,480 & 10,700 \\
\hline$?$ ?(20.01.99) & & & & & 0 & & & & & & & & & \\
\hline тОт & 116,817 & $1,865,753$ & $2,411,298$ & $2,690,996$ & $2,568,760$ & $2,870,225$ & $2,606,949$ & $1,990,581$ & $2,299,769$ & $1,953,974$ & $2,023,607$ & $1,898,362$ & $2,240,382$ & $2,131,655$ \\
\hline \multicolumn{15}{|l|}{ INDUSTRIAL } \\
\hline Wood, glass and plastic** & 1,038 & 16,576 & 21,423 & 23,908 & 22,822 & 25,500 & 37,600 & 5,040 & & 13,760 & 6,700 & 11,140 & 11,860 & 2,520 \\
\hline Waste from mixed construction work & & & & & 0 & & & & & & 42,140 & & 0 & 4,980 \\
\hline Furniture & 418 & 6,682 & 8,636 & 9,638 & 9,200 & 10,280 & & & & & & 13,520 & 35,780 & 10,360 \\
\hline Other municipal waste & 4,526 & 72,284 & 93,420 & 104,256 & 99,520 & 111,200 & 636,520 & $2,576,580$ & 993,000 & 439,860 & & & & \\
\hline Mixed industrial waste from companies & & & & & & & 915,260 & $1,249,000$ & $1,387,680$ & $2,713,300$ & $1,347,600$ & 891,640 & $1,605,080$ & $1,900,500$ \\
\hline TOT & 5,982 & 95,542 & 123,479 & 137,802 & 131,542 & 146,980 & $1,589,380$ & $3,830,620$ & $2,380,680$ & $3,166,920$ & $1,396,440$ & 916,300 & $1,652,720$ & $1,918,360$ \\
\hline
\end{tabular}




\begin{tabular}{|c|c|c|c|c|c|c|c|c|c|c|c|c|c|c|}
\hline TOTAL LANDFILLED IN CELLS 1-4 & 387,213 & $6,184,428$ & $7,992,752$ & $8,919,868$ & $8,514,691$ & $9,513,960$ & $10,706,430$ & $12,070,530$ & $10,541,690$ & $10,234,560$ & $8,997,480$ & $7,541,640$ & $9,461,960$ & $9,716,220$ \\
\hline & & & & & & & & & & & & \multicolumn{2}{|c|}{ Total landfilled 1999 - 2012} & $120,783,422$ \\
\hline \multicolumn{15}{|l|}{ Landfilled elsewhere } \\
\hline Carcasses and slaughterhouse waste & 0 & 884,000 & 623,000 & 407,000 & 203,000 & 16,480 & 4,840 & 10,520 & 42,500 & 119,180 & 86,220 & 445,520 & 233,270 & 95,420 \\
\hline Slaughterhouse and fish waste & 0 & 0 & 0 & 0 & 0 & 203,860 & 239,840 & 455,040 & 245,640 & 9,060 & 48,700 & 41,560 & 0 & \\
\hline Insulation and construction materials containing asbestos & 194 & 3,094 & 3,999 & 4,463 & 4,260 & 4,760 & 11,380 & 7,460 & 820 & & & & & \\
\hline Asbestos. Insulation materials. & 593 & 9,478 & 12,249 & 13,670 & 13,049 & 14,580 & 53,360 & 345,420 & 435,740 & 48,760 & 24,120 & 340,240 & 3,420 & 28,920 \\
\hline \multicolumn{15}{|l|}{ Final and daily cover materials } \\
\hline Chopped wood (for daily and final cover) ${ }^{* * *}$ & & & & & & $2,520,170$ & $2,941,460$ & $5,583,881$ & $3,299,000$ & $4,106,000$ & $2,379,000$ & $1,466,000$ & $2,193,000$ & $2,960,000$ \\
\hline Soil & & & & & & & 488,000 & 60,000 & $2,100,000$ & & & $5,852,000$ & $5,739,000$ & $6,517,000$ \\
\hline Gravel & & & & & & & 968,000 & 0 & & $9,665,000$ & $2,226,000$ & $2,820,000$ & 270,000 & 564,000 \\
\hline Fillings & & & & & & & & $2,832,000$ & & & & & & \\
\hline & & & & & & & & & & & & & & \\
\hline & \multicolumn{14}{|c|}{$=$ Waste quantities per category estimated based on total landfilled waste per year and waste composition in 2004} \\
\hline * & \multicolumn{14}{|c|}{ Cell 2 was filled until mid-year 2006, accounting for $49 \%$ of total landfilled waste that year. This is taken into account when modelling for cell 2 in the IPCC model. } \\
\hline ** & \multicolumn{14}{|c|}{ Very low percentage of wood according to technicians } \\
\hline$* * *$ & \multicolumn{14}{|c|}{ Approx. $10 \%$ of the chopped wood is used with the slaughterhouse waste. The chopped wood used as a daily cover is not taken into account into the IPCC model. } \\
\hline
\end{tabular}




\title{
Appendix C: Preliminary Gas Flux Measurements at the Álfsnes Landfill
}

\author{
Memo. Preliminary Gas Flux Measurements at Álfsnes and Gufunes landfills.
}

Gas flux measurements were carried out from the surface of the Álfsnes landfill on afternoons of May 4th and 7th 2012, including a few measurements at the old Gufunes landfill in Reykjavík early on May 4th 2012. Measurements were performed in order to test and become familiar with equipment from Iceland GeoSurvey (ÍSOR), a West Systems portable flux meter (LI820 and WS-HC), and to examine flux strength (order of magnitude) from the landfill surfaces. The West Systems flux meter uses the dynamic accumulation chamber method for the measurement of carbon dioxide and methane fluxes. The chamber and gas detectors are accompanied with a palm top computer in order to record and visualize concentrations of $\mathrm{CO}_{2}$ and $\mathrm{CH}_{4}$. A continuous reading of gas fluxes in the chamber is displayed on the screen. Using the touch screen, a regression interval can be chosen to determine a linear best fit that is used to calculate the flux $(\mathrm{ppm} / \mathrm{s})$. The flux and regression quality factor $r$ is displayed on the screen.

The Gufunes landfill was visited on Friday May 4th, between 10.30 and 11.30 AM, and flux measurements were performed in proximity to existing gas-monitoring wells (GG-2 - GG05 and holes nr. 106 and 107), installed in 2008 and 2003 respectively to measure the gas generation in the landfill. The weather was dry, sunny, about $10^{\circ} \mathrm{C}$, with a light breeze from the northeast to east $(2 \mathrm{~m} / \mathrm{s})$ and the air humidity was around $60 \%$. No $\mathrm{CH}_{4}$ fluxes were measured and only what appeared to be baseline $\mathrm{CO}_{2}$ was emitted from the surface. The Gufunes landfill was in operation from 1967-1991 and when it closed it was covered with large amounts of soil and building material. The thickness of the cover is estimated to be 2$5 \mathrm{~m}$ (Línuhönnun hf., 2008), and in many places up to more than $10 \mathrm{~m}$ thick according to former staff (pers. communication, SORPA). No common signs of landfill gas flux could be detected visually, e.g. fissures or damage to the newly emerged vegetation. According to a recent study (Línuhönnun, 2008), gas is still being generated in some areas of the landfill, but the gas likely migrates via lateral pathways and possibly reacts with leachate-mixed groundwater that flows to the ocean, or is almost entirely oxidized through the thick cover soil. This can only be verified upon further examination, e.g. with grid-based flux measurements or larger scale plume measurements.

The Álfsnes landfill was visited on a Friday afternoon, May 4th. The weather was partly cloudy, $\mathrm{NW}$-wind $4 \mathrm{~m} / \mathrm{s}$, wind gusts up to $6 \mathrm{~m} / \mathrm{s}$ and temperature $8^{\circ} \mathrm{C}$, moisture $64 \%$ according to the Icelandic Meteorological Office. The Álfsnes landfill, currently in full operation, is run by the intermunicipal firm SORPA, owned and jointly run by The City of Reykjavík and six other municipalities in the capital area, serving approx. 200000 inhabitants. The Álfsnes landfill has an unlined cover on top of cells, about 2- $5 \mathrm{~m}$ thick. Site technicians pointed out a few places on the landfill where gas flux from the surface is evident, e.g. by odour or cracks in the ground. A few measurements were carried out but there was a significant disturbance in the reading on the palm top computer, probably due to the strong wind and sharp wind gusts entering the chamber through cracks in the soil. Only one flux value was readable, measured in a relatively sheltered area on top of an apparent crack in the soil between two gas recovery wells, $30 \mathrm{ppm} / \mathrm{s} \mathrm{CH}_{4}\left(165 \mathrm{~g} / \mathrm{m}^{2} /\right.$ day $)$. 
The Álfsnes landfill was revisited Monday, May 7th 2012, at 10 am, to try the flux meter once again on top of different cells. Weather conditions during time of measurements are presented in Table I below according to data from the Iceland Meteorological Office and the in-situ SORPA weather station. For flux calculations, $\mathrm{T}=5^{\circ} \mathrm{C}$ and $\mathrm{P}=1010 \mathrm{hPa}$ were used as default values. During time of measurements, landfill gas seemed to stem from the surface everywhere, judging by the odour and distorted flickering view. Measurements began at ca 10:30 am, after 20 minutes of instrument warm-up time. Each measurement took 4-6 min, or until a clear regression line could be chosen from the data acquired from the flux meter, $r$ $>0.9$. Since palmtop computer displays instantaneous $\mathrm{CH}_{4}$ and $\mathrm{CO}_{2}$ fluxes, any disturbances or abnormalities in measurements can be identified and discarded when choosing the regression line. The accuracy of the flux meter is $25 \%$ for methane and carbon dioxide readings. Measurements are summarized in Table II, based on chamber dimensions and the ideal gas law.

Table I: Weather conditions during time of flux measurements, May 7th 2012, 10:30 am.

\begin{tabular}{|l|l|l|}
\hline & $\begin{array}{l}\text { Icelandic Meteorological Office } \\
\text { (at Bústaðarvegur, central Reykjavík) }\end{array}$ & $\begin{array}{l}\text { SORPA Weather Station } \\
\text { (at Álfsnes) }\end{array}$ \\
\hline Air temperature & $5^{\circ} \mathrm{C}$ & - \\
\hline Wind speed & $1-2 \mathrm{~m} / \mathrm{s}(\max 3 \mathrm{~m} / \mathrm{s})$ & $2-5 \mathrm{~m} / \mathrm{s}$ \\
\hline Air humidity & $60 \%$ & $50 \%$ \\
\hline Atm. pressure & $1017 \mathrm{hPa}$ & $1015 \mathrm{hPa}$ \\
\hline
\end{tabular}

Table II: Flux measurements at Álfsnes, May 7th, 2012, 10:30 am.

\begin{tabular}{|c|c|c|c|c|c|c|}
\hline $\begin{array}{l}\text { Meas. } \\
\text { no. }\end{array}$ & $\begin{array}{l}\text { Cover } \\
\text { thickness }\end{array}$ & $\begin{array}{l}\text { Thickness } \\
\text { of waste }\end{array}$ & Landfilled & Info & $\begin{array}{l}\mathrm{CH}_{4} \\
{\left[\mathrm{~g} / \mathrm{m}^{2} / \mathbf{d}\right]}\end{array}$ & $\begin{array}{l}\mathrm{CO}_{2} \\
{\left[\mathrm{~g} / \mathrm{m}^{2} / \mathrm{d}\right]}\end{array}$ \\
\hline $1 \mathrm{a}$ & $2-2.5 \mathrm{~m}$ & $9.8-10 \mathrm{~m}$ & 2002-2003 & $\begin{array}{l}\text { Cell no.6. Measured over crack in } \\
\text { soil, between holes } 6325 \text { and } 6330 . \\
\text { Acc. to technician, no gas is being } \\
\text { extracted from the two holes. }\end{array}$ & 45.5 & --- \\
\hline $1 \mathrm{~b}$ & $2-2.5 \mathrm{~m}$ & $9.8-10 \mathrm{~m}$ & 2002-2003 & -idem- Measured from same place. & 117.7 & --- \\
\hline 2 & & & 2002-2003 & $\begin{array}{l}\text { Cell no. 6. No apparent crack in soil, } \\
\text { only soil and gravel. }\end{array}$ & 2.2 & 0 \\
\hline 3 & $4 \mathrm{~m}$ & $8 \mathrm{~m}$ & 2009 & $\begin{array}{l}\text { Cell no. } 8 \text {. Measured over apparent } \\
\text { crack in soil. Soil was generally loose } \\
\text { (not compacted). }\end{array}$ & 30.2 & 9.5 \\
\hline 4 & $5 \mathrm{~m}$ & $13 \mathrm{~m}$ & 2009 & $\begin{array}{l}\text { Cell no. } 8 \text {. Measured over compacted } \\
\text { area. Strong odour and visible waste. } \\
10 \mathrm{~m} \text { north of ditch for gas collection } \\
\text { pipe. }\end{array}$ & 0.0 & 0 \\
\hline 5 & & & $\begin{array}{r}\text { Before } \\
2002\end{array}$ & $\begin{array}{l}\text { Older cell (no.?) Vegetation } \\
\text { developed (grass, dandelions, } \\
\text { angelica). Measured over moist and } \\
\text { vegetation-free patch. A lot of } \\
\text { "noise" in flux measurements } \\
\text { (increases with low concentration). }\end{array}$ & 0.4 & 2.2 \\
\hline
\end{tabular}

$\mathrm{CH}_{4}$ concentrations ranged from 0 to $117.7 \mathrm{~g} / \mathrm{m}^{2} /$ day. When two measurements were carried out on the exact same location on cell 6 , very different results were obtained, i.e. in the 
second measurement the flux was more than two times higher than the previous measurement. High temporal variability has been reported in gas fluxes from landfills, although one cannot rule out that this difference might be the result of an error in measurement technique. In cell 6 , the "quality" of landfill gas being extracted through the extraction system is now considered sub-par for utilization (pers. communication, SORPA), and in many of its wells extraction has stopped. According to flux measurements, gas is however still being generated and is being emitted to some extent through the cover.

Cell no. 8 is more recent and when measuring from two locations on top of the cell, gas flux was detectable on top of loose non-compacted soil, but non-detectable on top of compacted soil (visible bulldozer tracks), despite an ominous strong odour. The compacted soil might drive the gas to migrate via areas that are less compacted, and the strong odour detected might originate from areas farther away, carried by the breeze, and not necessarily from cell no. 8 .

One measurement was carried out on top of an older cell, landfilled before 2002, where the cover had become well vegetated. The chamber was placed on top of a moist and vegetation free patch in the ground, which might be an indicator of gas flux. Relatively low flux concentrations were measured there in comparison to values obtained from other cells, i.e. $0.4 \mathrm{~g} \mathrm{CH}_{4} / \mathrm{m}^{2} /$ day.

Hot spots can often be detected visually by seeking cracks on the surface or moist patches, often accompanied by a distinct odour. High emission areas can however easily be missed, and given the very small area of the flux meter chamber used, a tight grid of measurements would have to be made to account for spatial variability of gas flux on top of each cell. The results presently obtained are only indicative of the range and magnitude of fluxes that can be encountered on top of the landfill.

Strong wind and wind gusts seem to have an impact on measurements, especially when flux concentrations are low $(<0.1 \mathrm{ppm} / \mathrm{s})$. Measurements are therefore best carried out in dry, still weathers (usually in the mornings), if possible. A 20 min warm-up time is needed for the WS instrument, before results can be considered reliable.

\section{References:}

Línuhönnun, 2008. Urðunarstaður í Gufunes: Mcelingar og áhottumat vegna fyrirhugaðrar breytingar á landnotkun. Umhverfis- og samgöngusvið, Reykjavíkurborg.

West Systems, 2007. Portable diffuse flux meter. Carbon dioxide, Methane \& Hydrogen sulfide. Handbook. Release 7.00 July 2007, http://www.westsystems.com 